\title{
11. A SZÉKELYFÖLDI CÉHEKRŐL
}

„A város középpontján lévő nagy kiterjedésü piac egyike honunk legszebb vásárterének; kár azonban, hogy az oda épített városház, csizmadia- és tímárszínek által meg van szaggatva, s több részekre felosztva. Ennek északi részében van a Ferencrendiek kolostora nagy, kéttornyú templomával." (Orbán 1868. 52.)

Az elmúlt századokban a vásártereken találkoztak a vidéki lakosság mezőgazdasági termékei a város kézművesipari ${ }^{1}$ termékeivel. Szinte mindenki, aki megjelent a vásártéren, vásárló és ugyanakkor eladó is volt. Ezen túl az udvarhelyi vásártér jellegzetessége volt a sópiac ${ }^{2}$, ahol a parajdi bányában vásárolt sót adták tovább a sókereskedelemmel foglalkozó magánszemélyek. A „sópiac” rendezését 1670-ben az országgyűlés törvény alkotásával kísérelte meg. ${ }^{3}$ A gabonapiacon az udvarhelyszékiek és a csíkiak vásárolhatták meg a város és a szék ellátásához hiányzó gabonát, ${ }^{4}$ a búzát a Szászföldről érkező gazdáktól, a rozsot a Hargitán átszekerező csíkiaktól. Ezek az egyszerűnek tűnő megállapítások a valóságban egy nagyon bonyolult, a privilégiumok sokaságában fuldokló, sok megkötöttséggel működő gazdasági rendszert takartak, amelyben az ipari termelést nagyobbrészt a céhek biztosították. „A városok piacterein álló »árulószínek« nyitását-zárását a szolgáló céhlegények kötelességévé tették a céhmesterek. Szigorú szabályok írták elő az eladás rendjét is: ki hol, mikor árusíthat, milyen árut és mennyit, és ezt felsôfórumaik is gyakran megparancsolták, milyen árat kérhet termékeiért. Ezek a kőből rakott, fából ácsolt színek és sátrak voltak a hetivásárok, sokadalmak alkalmával, az országos nagyvásárokról nem is szólva, a földet múvelók ipari termékellátói. A különböző foglalkozási rétegek, hegybeli és síkföldi lakosok találkozási helyein - az árucsere forgalom empóriumain - tehát mind több és változatosabb árucikket igényelt a földet müvelő ember is." (Imreh 1979.174-175.)

A vásárok vagy sokadalmak alkalmával a törvények, rendeletek és a helyi szokások betartatásáért a város felelt, amely rendszerint a vásárjog tulajdonosa is volt. A vásárjoggal rendelkező városokban a termelők (kézmúvesek, iparosok) mellett megjelentek a kereskedők. Nem tudjuk, hogy Székelyudvarhely mikor és kitől kapott vásárjogot. $\mathrm{Az}$ is lehetséges, hogy a székelyek letelepítésének forráshiányos időszakában a szükséglet hozta létre és szokások éltették tovább a vásárokat. $\mathrm{A}$ vásárrendtartásokban írták le az időpontját, időtartamát. A vásárjog a városok egyik legfontosabb privilégiuma volt, bevételeket biztosított a közösség számára, és jövedelemhez juttatta a helyi lakosságot.

A városok arra törekedtek, hogy kiváltságaikat fejedelmi oklevélben biztosítsák. Bethlen Gábor a vásár jövedelmeit a városnak adta. I. Rákóczi György 1637-ben elrendeli, hogy idegenek 10 óra előtt gabonát nem vásárolhatnak az udvarhelyi piacon, ez a helybeli lakosságnak volt fenntartva. Ezért panaszkodtak is a csíkiak, akik innen pótolták a hiányzó termésüket. 

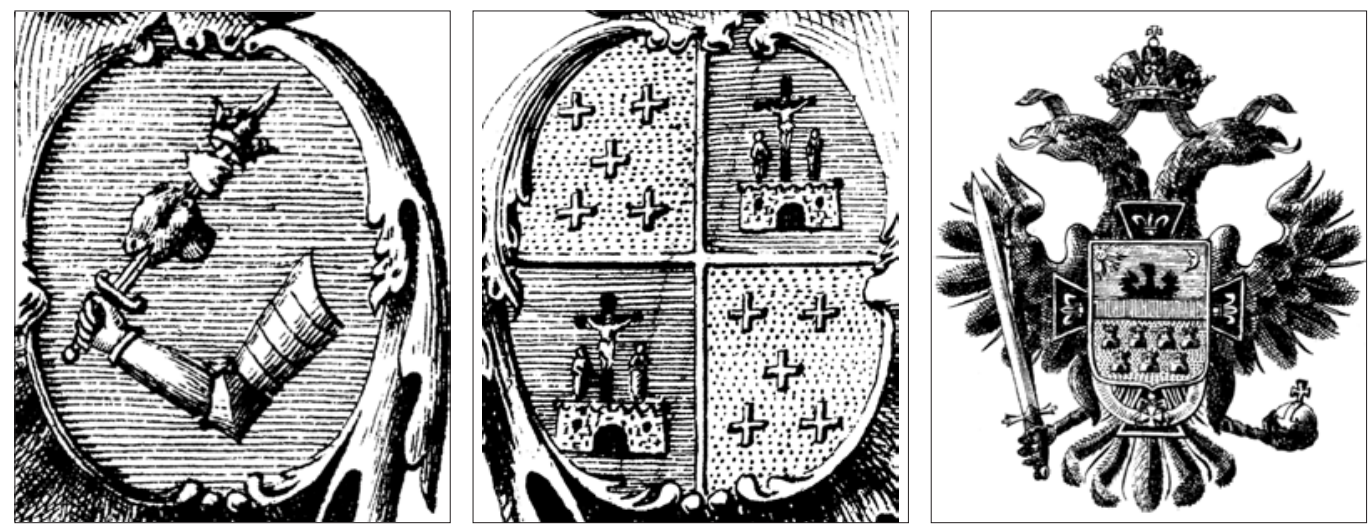

1. kép. Székelyudvarhely város, Udvarhelyszék és Erdély címere a mészáros céh I. Ferenc 1809. április 6-án adományozott statútumán (tusrajz)

Vásáros napokon a piactereket körülvevő állandó jellegú üzletekben is megnőtt a forgalom és vele együtt a bevétel. Ez történt a város vendéglőiben és a szolgáltatásokat nyújtó üzletekben (borbély) is. A piac közben differenciálódott. Külön területet kapott a fapiac ${ }^{5}$ vagy a baromvásár. A 19. század második felében egyre nagyobb súlyt kapnak a nagyállatvásárok.

Székelyudvarhely nagy központi terén és mellékutcáiban, a széles Botos utcában tartott vásárok regionális szempontból a termékek cseréjének legjelentősebb fórumai voltak. Lakatos István 1702-ben a Székelyföldről megjelent munkájában kiemelte a székelyudvarhelyi vásárok jelentőségét. Évente három országos vásárt tartottak, és minden kedden hetivásár vagy hetipiac volt. „Mind a kétféle vásáron dúskálni lehet csaknem mindenféle holmiban és pedig húsfélékben, fában, sóban, állatban, búzában, különféle hüvelyesekben, halakban, majorságban, az évszakhoz mérten más és más fajtájú gyümölcsökben, pogácsákban, portékákban és egyéb, az emberi élet fenntartásához és kényelméhez szükséges dolgokban." (Lakatos 1942. 12-13.) A templomukból kiszorult katolikusok a miséket a piacon tartották az iparosok sátrában.
Száz évvel később Szigethy Gyula Mihály, az 1670-ben alapított református kollégium neves tanára is megemlékezett a város és vidéke mesterségeiről: „A' mesterségek $a^{\prime}$ nemes székben sokfélék, bővek, 's a székbeliek szüksége kielégítésére szinte elégségesek" - írta 1829-ben. - Udvarhelyen is vannak jó mesterek: "fáin selyem kalapokat készítő kalaposok; asszony s férfi köntös darabokat a legújabb módra csinálni tudó szabók, bőr-leibit, ködmönt, kozsokat, bundát, kucsmát, bőrsapkát, kesztyút készítő szőcsök, fényes módoson készült stibliket varró schusterek, kik külföldeken vitték mesterségbeli tanulságokat tökéletességre." Annak ellenére, hogy sok mesterember elhagyja mesterségét és kereskedelemre adja magát. Ennek oka „a pénznek szúkvolta, az életnek drágasága", a mesterek viszonylag nagy száma a fogyasztók számához viszonyítva. A csizmadiák, szabók, vargák ronggyal, vassal, szalonnával, dohánnyal, borral, mézzel, bárány-, ló-, ökör-, juh- és kecskebőrökkel kereskednek. A báránybőröket szekérszámra adják el az örményeknek, vagy viszik Debrecenbe. A helyi mesterek csak másod-, harmadkézből jutnak hozzá, akkor is jó drágán. Legjobban jövedelmező mesterségek a kalapos, szappanos, a talpcsi- 
náló (érlelő) vargáké, a kenyérsütőké (pékeké), asztalosoké, akik „fáin rakott asztalokat, kaszteneket, divánokat, ládákat, töltött székeket sokszor válogatott fákból csinálnak", de sokszor készen is lehet ilyeneket találni. Az 1820-ban összeírt jobbágyvallomásokban a vásárokra is találunk kérdést és válaszokat. 1820-ban Udvarhelyszékben is végrehajtották a Cziráky-féle összeírást (Conscriptio Czirákyana) (Takács 2001). Az úrbéri összeírás egyik kérdése a látogatott vásárhelyekre vonatkozott. A kérdésekre adott feleletekből kirajzolhatjuk az egyes vásárok vonzáskörzetét. A székelyudvarhelyi vásárt elsősorban
Udvarhelyszék falvaiból látogatták. Vonzáskörzete gyakorlatilag lefedte az egész széket, kivéve az Erdővidéket és a Partiumot, a nyugati peremvidék falvait, ahol már gyengült a vonzereje. A vásárhiányos Kelet-Erdély „egyetlen fontosabb vásárközpontja Székelyudvarhely" (Sonkoly 2003. 168.).

Az udvarhelyi vásárt 1820-ban a városban lakó jobbágyok így jellemezték: „Itten esztendőnként négy sokadalmak és heti vásárok szoktanak esni, és ki-ki szabadoson mindenféle italt korcsomárolhat. Ezen conscribált részen ugyan a városnak boltok nincsenek, hanem lakosai nagyobbára mesteremberek,

1. táblázat. Udvarhelyszéki vásárok (Kozma Ferenc 1879; Kardalus János 1985; István Lajos 1977)

\begin{tabular}{|c|c|c|c|c|}
\hline Város, falu & Vásárjog & Országos vásár & Hetipiac & $\begin{array}{l}\text { Vonzáskörze- } \\
\text { tében lévő fal- } \\
\text { vak } 1820 \text {-ban }\end{array}$ \\
\hline $\begin{array}{l}\text { Székelyudvarhely, oppi- } \\
\text { dum, taxás város, királyi } \\
\text { taxás város, r. t. város }\end{array}$ & eredete ismeretlen & $4+$ & kedd & 94 \\
\hline $\begin{array}{l}\text { Székelykeresztúr, mezővá- } \\
\text { ros, város, nagyközség }\end{array}$ & $\begin{array}{l}\text { 1. korai vásárjog-adomá- } \\
\text { nyozó ismeretlen } \\
\text { 2. Bécs }\end{array}$ & $\begin{array}{l}\text { február } 24 . \\
\text { május } 4 . \\
\text { szeptember } 14 . \\
\text { július } 7 .\end{array}$ & szombat & 44 \\
\hline Bögöz & 1868. március 12. & 4+1 marhavásár & & \\
\hline Etéd & $\begin{array}{l}\text { Báthori Zsigmond adomá- } \\
\text { nyozta 1593. április } 26 \text {-án }\end{array}$ & $4+1$ & egy & 16 \\
\hline Farkaslaka & & 2 & - & \\
\hline Homoródszentmárton & $\begin{array}{l}\text { I. Ferenc, Bécs, } \\
\text { 1808. január } 29 .\end{array}$ & $\begin{array}{l}\text { február } 24 . \\
\text { május } 16 . \\
\text { augusztus } 29 .\end{array}$ & 1 & 19 \\
\hline Korond & $\begin{array}{l}\text { Gróf Gyulaffy László } \\
\text { kérésére a szentdemeteri } \\
\text { vásárt tették át Korondra. } \\
1749 \text {. augusztus } 3 .\end{array}$ & $\begin{array}{l}\text { január } 25 . \\
\text { május } 13 . \\
\text { július } 4 . \\
\text { augusztus } 25 . \\
\text { november } 20 .\end{array}$ & szombat & 13 \\
\hline Oláhfalu & & & 3 & \\
\hline Oklánd & 1864 & & & \\
\hline Parajd & $\begin{array}{l}\text { Ferenc császár, } 1802 . \\
\text { november } 11 . \\
\text { A júliusit I. Ferdinánd } \\
1847\end{array}$ & $\begin{array}{l}\text { március } 19 . \\
\text { október } 15 . \\
\text { december } 17 . \\
\text { július } 26 .\end{array}$ & csütörtök & 13 \\
\hline Zetelaka & & & & \\
\hline
\end{tabular}




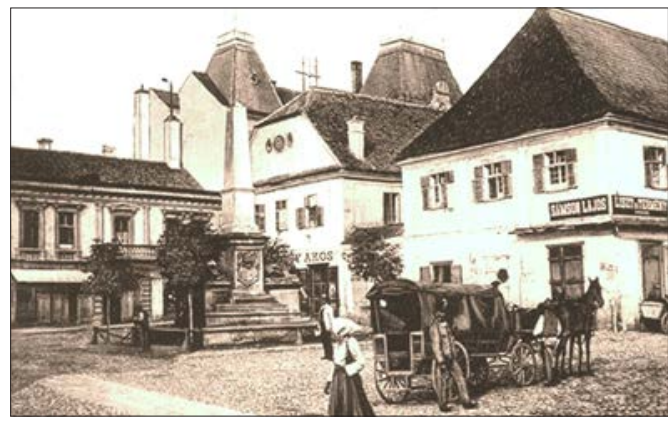

2. kép. Székelyudvarhely piactere a 20. század elején a millenniumi emlékoszlop és a városháza látványával. Háttérben a „barátok” temploma

akik taxát fizetnek. Hanem, mivel ezen része a városnak a többi részével egy contiquitásban vagyon, a városi boltok és céhok hasznaival élnek. Ugyanazért azok, s egyéb beneficiumot importálók is felvétetvén. Vagynak a városon nagyobb kereskedőboltok 5, apróbb boltok 22, vasáruló boltok 2, borbélymühely 2. Mesteremberek többnyire lakosai, kiknek vagynak cehái: 1-o. csizmadia, 2-o. talpkészítő tímár, 3-o. kordovány készítő tímár, 4-o. szabó, 5-o. szőts, 6-o. kalapos, 7-o kovács, lakatos, 8-o. szígyártó, 9-o. kőmíves, 10-o. mészáros céhok 11-o. két szappanyföző, 12-o. egy takács, 13-o. sok ács mesterember, 14-o. serföző 3" vallották a székelyudvarhelyi vallomástevők (Takács 2001. 158.). „Udvarhely városa ide gyalog fél óra. Ökörrel menve egy óra járó distantia, ahová mindenütt csinált, töltött úton visszük a természetnek minden jovait, és minden vásárvám nélkül commoda distrahálylyuk." (Takács 2001. 161.) Bethlenfalva lakói jól kihasználhatták a piac közelségét és a kövezett út előnyeit.

Az 1895-ben a városba kebelezett Szombatfalva számára is előnyös a város közelsége. „Udvarhely városában ki-ki szabadon hordja a tüzifát, feleségeink tejet, tojást, vajat, tyúkot, csirkét és veteményt hordanak eladni.

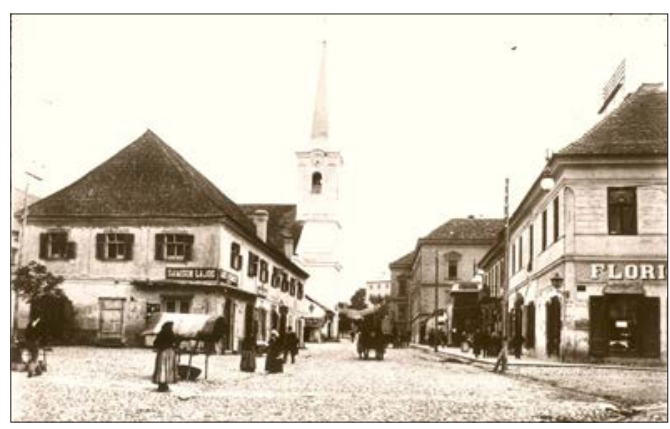

3. kép. A székelyudvarhelyi piactér déli oldala az „árulószinnel” és a Kossuth Lajos utca bejáratát jelző Flórián üzlettel

Emellett most a havasunk el lévén pusztulva, a szomszédos havasos faluktól vagy pénz[z]el, vagy a nyereségből fordulandó gabonával fenyőt árendálunk ki, és abból boronafát, edényeket, szőlőkarót és más müveket csinálunk, s hordjuk eladni. És az ezekből jövő nyereségból segítünk a határunk terméketlenségin." (Takács 2001. 197.)

A Székelykeresztúr szomszédságában lévő Csekefalva lakói számára is Udvarhely és Segesvár volt a „vásáros hely”. Keresztúrt így említették: „egy harmadik hetivásáros hely is, éppen a szomszédban” (Takács 2001. 245.). A kisgalambfalvi jobbágyok számára is Székelyudvarhely és Segesvár a vásáros hely. „Valamiképpen ezen két városokban az ottan található mesteremberek által egy falusi gazdaember minden házi környülállásaira nézve megkívántató dolgokat és szükségeket kipótolhat és megszerezhet." Itt is harmadiknak említik a keresztúri vásárt, amely legközelebb van a faluhoz: „Vagyon még egy harmadik és hasonló vásáros hely, úgymint Keresztúr, amely ide egy órányi járóhely, holott is apróbb dolgokat lehet szerezni és eladni." (Takács 2001. 260.)

A déli irányból, a Homoródok völgyéből Székelyudvarhelyre vezető út mellett a pa- 
takfalviak sajátos pihenőhelyet alakítottak ki. „Hanem a Serestető nevezetü hegy, az Udvarhely felé menő út ott mégyen el, -szabadoson korcsmárolhat ott akárki, mikor sokadalom esik a városban." (Takács 2001. 148.) A szombatfalviak is kihasználták a vásáros hely közelségét, „van a város mellett egy bocskoráruló helyünk melyért árendát fizetnek". (Takács 2001. 195.).

„Udvarhely, az hová is innen Lövétéröl szekérrel nem vihetünk semmit eladni a nagy hegyek mián. Hanem marhát, mikor sokadalom esik, elhajthassuk, el is adhassuk. [...] Ez utak mind alkalmatlanok, hegyes és völgyes helyek." (Takács 2001. 88.)

A lövéteiek vallomása figyelmeztet a vásározás nehézségeire. A jó, kövezett utak hiánya fékezte a pénzforgalom nagyobb fokú elterjedését. A kisparaszti gazdaságokban igyekeztek minden szükségest megtermelni, és csak a legszükségesebb árucikkekért mentek a vásárba.

„Különben Homoród Szent Márton a két Homoród mellékének legvirágzóbb községe, mit leginkább látogatott országos sokadalmainak lehet feltudni. Homoród Szent Márton sokadalmait Ugron Pál, Kováts László és Lukácsfi Elek közbenjárásukra és kérelmükre engedélyezi I. Ferenc Bécsből 1808-ban, jan. 29-én maga, gr. Teleki Sámuel és gr. Eszterházi János aláirása alatt kelt okmány által. Engedélyezett pedig három országos sokadalmat, elsôt sz. Valens napjára vagy február 24-ére, másodikat Nep. Sz. János napjára vagy augusztus 29-ére. A fökormányszék kihírdette azt 1808. év szept. 8-án tartott ülésében. Az okmány hiteles másolata megvan Baróthon Zathureczki Lászlónál. Homoród-Sz. Márton sokadalmai nagyon látogatottak, a két Homoród mentén csak is ezen egyetlen vásáros hely lévén. Baromvásárai árszabályozók a Székelyföld nagy részére nézve."

A szombatfalviak és más falvak lakói is panaszkodtak, hogy a só oly drága lett, hogy nem érdemes kereskedni vele, pedig ez korábban jövedelmező volt. „A sóakna ide két mérföld, s amég így meg nem drágult a só, addig inkább kereskedtünk vele, de most a házunk szükségére valót is alig tudgyuk kiszerezni." A kincstár tulajdonát képező sót, amely a parajdi bányában bőven volt, egyre drágították, míg olcsóbb lett a Moldovából csempészett só (Takács 2001. 197.). A székelyudvarhelyi vásárok sajátossága volt a sóvásár. A vásártér északi részén volt a sóvásártér, ahova a parajdi sót hozták és árusították. A Sópiac utcában volt örökölt háza Téglás Györgynek a 18. század közepén (Téglás 1910. 54.).

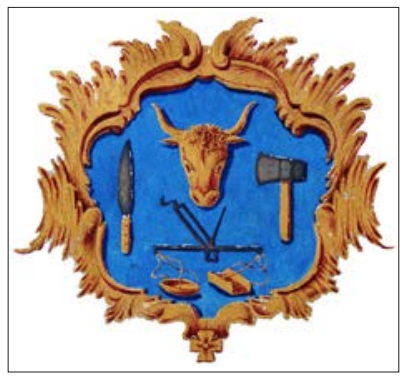

4. kép. Mészároscímer a céhprivilégium dísze

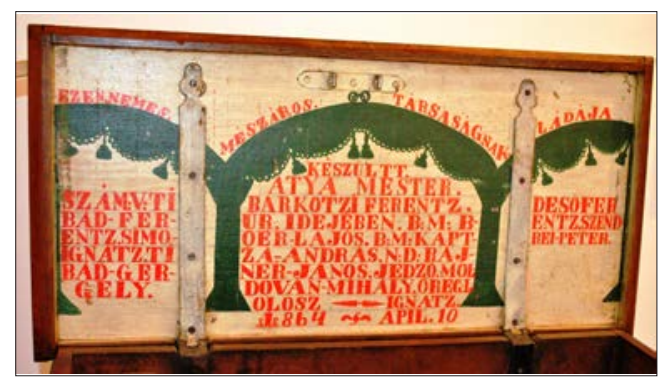

5. kép. Mészároscéhláda fedelének belső feliratos oldala (1864)

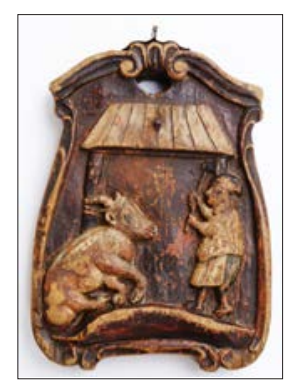

6. kép. Mészárosbehívótábla elólapja 
„A' parajdiak és sófalviak kereskednek föképpen Udvarhellyre fél másás és kisebb darab kő sókkal: ott helyben kaphatni apró darab sót is vékájába. A kő sókat vagy Parajdon adják el az oda egyenesen ment szekereseknek, vagy Udvarhelyre hordják, kiktől a székbeliek, közel fekvő szász helységek, Tsikiak, Háromszékiek, Erdővidékiek szekerekkel veszik, s' hordják haza, fél másáért öt Rforintokat adván váltó tzédulában." (Szigethi 1831. 84.) „Itten a sóbánya az falunkban vagyon, mellyel szabadon lehet kereskedni. Udvarhelyig jó úton, másfelé pedig alkalmatlan úton. Deszkával, léccel s más egyéb fenyőfa eszközökkel is szoktak pénzt keresni. Nevezetesen házi sót is adnak a kamarától minden gazdaembernek a háza népe s marhája menynyisége szerént, melyért pénzt nem kell adni.
Ezeken kívül még kereskednek a gyergyai, vagyis borszéki borvízzel, melyet elvisznek Kolosvárig, Vásárhelyig, s másfelé is, ahol becses ezen borvíz, s jó áron eladgyák. Szabad a colonusoknak a mészárlás, halászat, korcsomállás és a vadászat, a pálinkafözés is, mikor nem tiltatik." (Takács 2001. 227.) Így számoltak be a só-és ásványvíz-kereskedelemről a parajdiak.

A vásár jellegzetes színfoltja a borvízárus volt, aki a távolabbi Borszékről hozott vizet szekerekről árulta, de hoztak ásványvizet a közeli Szejkefürdőről is. „Közben-közben találkozunk egy borszéki borvizes emberrel, ki egyre-másra hat krajcárral adja a borvizet literes üveggel, melyet másutt az üzérek kapzsisága miatt méregdrágán lehet kapni." (Laukó 1888. 395.)

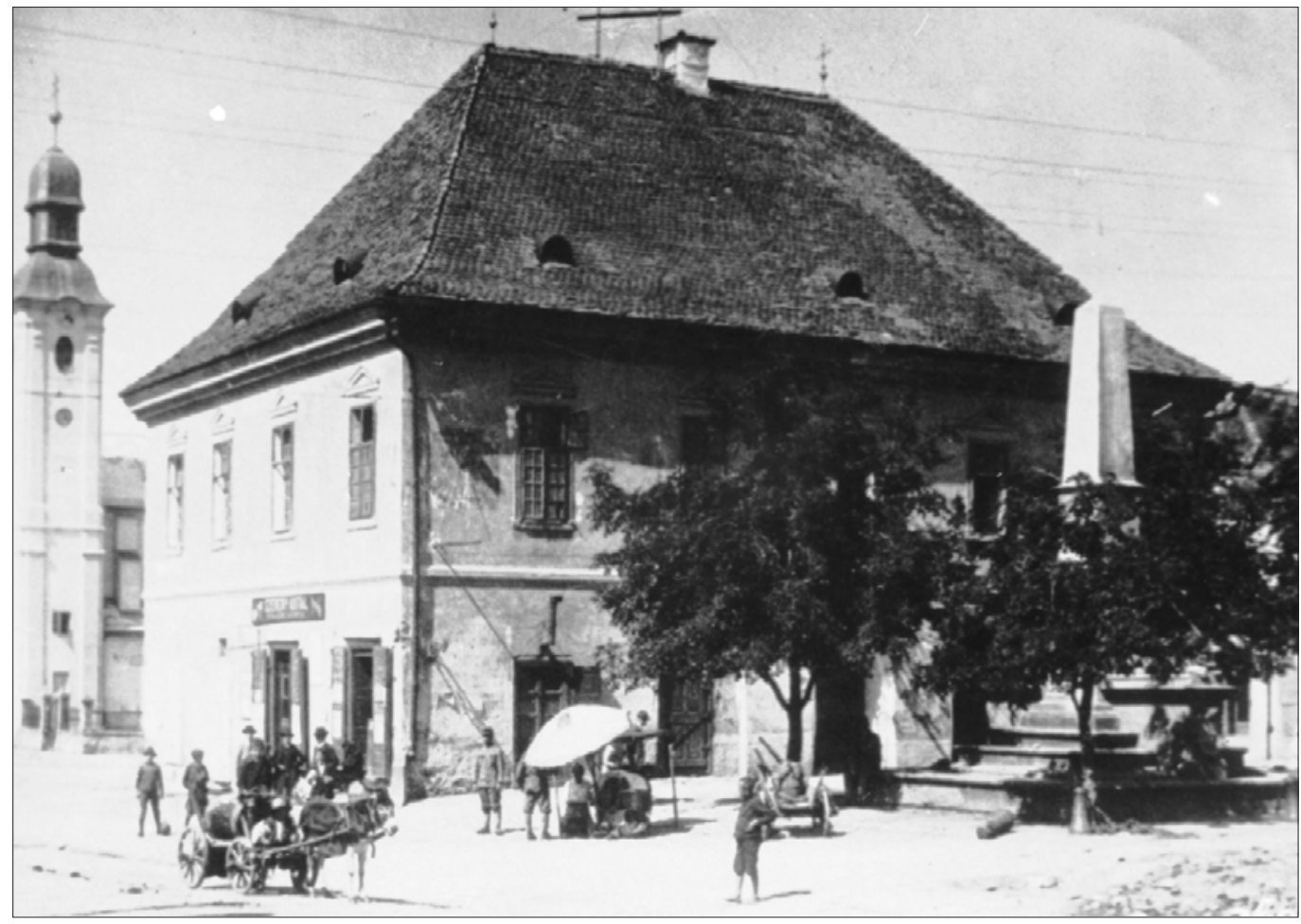

7. kép. A milleniumi emlékoszlop Székelyudvarhelyen, háttérben a vármegyeháza a céhek árulószinjeivel, elötérben az omnibusz 
A székelyudvarhelyi vásárok más nevezetességeit emeli ki 1842-ben Nagy Ferenc a Kolozsváron kiadott Mentor. Erdélyi népkönyv, közhasznú ismeretek tára címú gyakorlati ismereteket közlő kiadványban. „Székely Udvarhely. Vásárait két dolog nevezetesíti. Asztalosi mestermívekre való igen szép cseresznye-, kóris- és diófadeszkát Udvarhely $s$ környékén gyakran feles számmal lehet találni. Vásáraiban az Oroszhegyen s Sóvidéken termö eredeti, székely fajtájú lovakat noha nem nagy mennyiségben, az ahhoz értő megismerheti." (Nagy 1842. 338.)

Ugyanitt a székelykeresztúri vásárok esetében a májusi juhvásárt emelték ki és a régen nagyszámban felhozott, helyben készített szitákat (Molnár 1974. 186-189.).

Etédnek a szarvasmarhavására a legfonto- sabb. 1908-ban Székelyudvarhely belügyminiszteri engedéllyel juhvásárok szervezésére kapottengedélyt. Ezeket minden éváprilis 1011-12-én és szeptember hónap 28-29-30-án rendezték. Az udvarhelyi vásárok rendjéről sem sokat tudunk. Késői vásárrendtartása csak 1893-ban jelent meg (Zepeczaner 2010). Feltételezhetjük, hogy a vásárosok elhelyezésében nem történtek nagy változások. Ez nem jelenti azt, hogy korábban ne lettek volna szabályozva vásárai.

A piactér esős időben sáros volt, és csak a 19. század első éveiben kezdték el kövezését. „A Botos-utcza üsmég végig kővel kirakatott” 1817-ben, majd „A Bethlen-utcza is kiköveztetett, kirakatott" 1818-ban, Keszler Daniel bíróságában „a Botos-utcza végétól a Bethlen utcza végéig a ref. templom és collegium

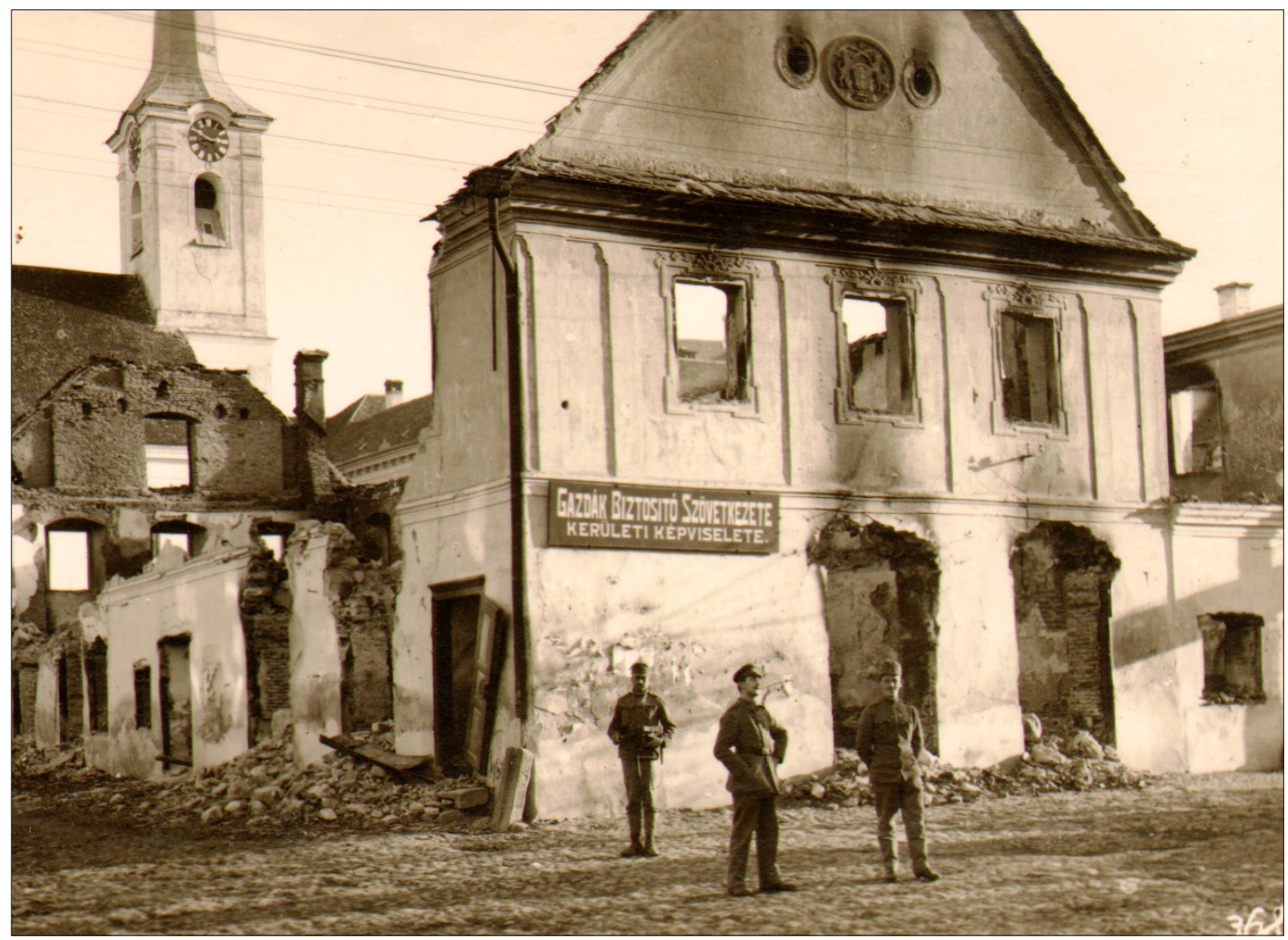

8. kép. Az 1916-ban leégett székelyudvarhelyi árulóhelyek 

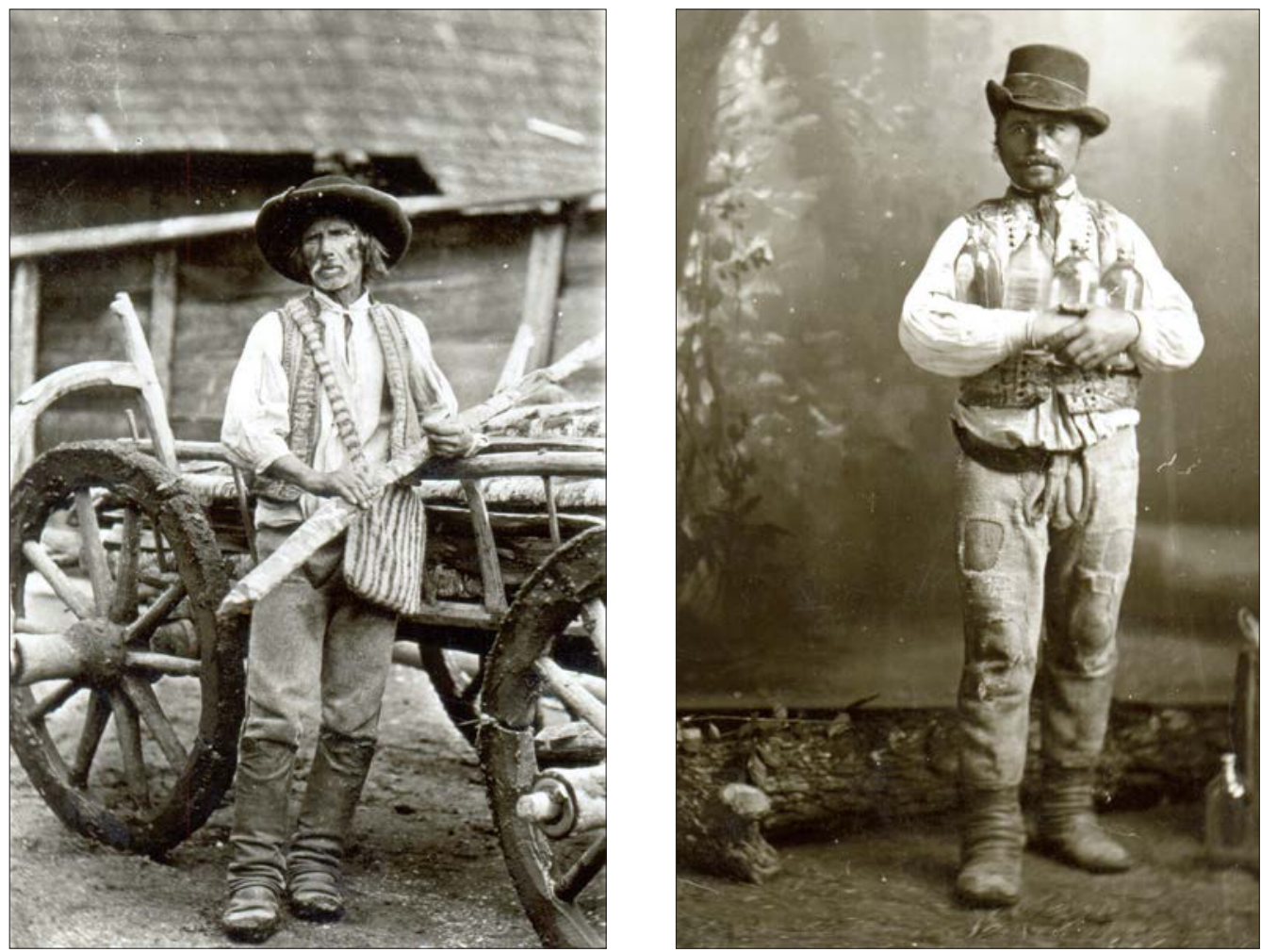

9. kép. Az székelyudvarhelyi vásár jellegzetes alakjai a zetelaki tüzifaárus és a borvízárus

elôtt kővel kirakatott" (Szeles -Szájdler 1898. 602.). A vásárterek használatára vonatkozó igények megerősödése a városiasodás terjedéséhez is hozzájárult.

Homoródszentpéter: „Emporiumai ezen helységnek vagynak. Legjobb Udvarhelly, melly ide szintén másfél mérföldnyire esik. Az hol jó hetivásárok és sokadalmak vagynak vagy esnek. Oda járunk adni, venni, s ott mindent adhatunk, vehetünk jutalmason."

Patakfalva: „Hanem a Serestető nevezetú hegy, - az Udvarhely felé menő út ott mégyen el - szabadoson kocsmárolhat ott akárki, mikor sokadalom esik a városban."

Székelyföldön három város érte el a gazdasági, társadalmi élet fejlődésének azt a szintjét, ahol már megvoltak a feltételei a céhek létrejöttének. A céhek statútumok, privilé- giumok alapján múködő, önkormányzattal rendelkező, feudális jellegű termelőegységek voltak. Megalakultak a statútumok előírásainak betartatásával a tagok, mesterek jogainak védelmére. Téves az az elképzelés, hogy a céhek csak az idegenektől, a külső veszélyforrásoktól védték a tagjaikat. A céhek nagyon szigorúan betartatták szabályzataikat, amelyek átszőtték a tagok életének minden síkját, ugyanakkor a munkát mindenki maga végezte, a maga kockázatára. A rendtartások nem engedték meg a nagyobb mozgásteret a tagoknak és a céh elöljárói számára. Minden határozathozatal és annak végrehajtása is a céh nyilvánossága előtt történt, és ez a szabályok áthágását mindenki számára lehetetlenné tette. A céh hozzájárult a közös érdekből fakadó szükségletek kielégítéséhez - mint a 
2. táblázat. A székelyföldi céhek alakulása és osztályozása a felhasznált nyersanyag szerint

\begin{tabular}{|c|c|c|c|c|}
\hline & $\begin{array}{l}\text { Marosvásár- } \\
\text { hely }\end{array}$ & Székelyudvarhely & Kézdivásárhely & $\begin{array}{l}\text { A mesterség } \\
\text { latin neve }\end{array}$ \\
\hline \multicolumn{5}{|c|}{ Élelmiszer- és vegyi alapanyagok feldolgozása } \\
\hline mészáros & 1493 & 1630 & 1809 & lanio \\
\hline szappanfőző & 1749 & & & saponarius \\
\hline \multicolumn{5}{|c|}{ Fémfeldolgozás } \\
\hline kovács & 1519 & & & fabros \\
\hline lakatgyártó & 1581 & 1613 & & faber serrarius \\
\hline ötvös & 1632 & & & aurifaber \\
\hline csiszár, fegyverkovács & 1615 & & & politor \\
\hline pajzskészítő & 1615 & & & \\
\hline üstgyártó & & & 1844 & ahenarius \\
\hline \multicolumn{5}{|c|}{ Bőrfeldolgozás } \\
\hline csizmadia & 1629 & 1635 & 1639 & coturnarius \\
\hline nyerges & 1519 & & & sellipares \\
\hline tímár- és varga- vegyes céh & 1519 & 1577 & & sutores \\
\hline szíjgyártó & 1519 & 1779 & 1813 & coriagiatores \\
\hline szücs & 1513 & 1579 & 1649 & pellifices \\
\hline tímár-varga & 1584 & & 1572 & cerdo \\
\hline cipész & & 1863 & & sutor \\
\hline kordovános & 1800 & 1818 & & \\
\hline \multicolumn{5}{|c|}{ Textilanyagok feldolgozása } \\
\hline erszényes & 1657 & & & zonarius \\
\hline süvegesek & 1657 & & & petararius \\
\hline gombkötő & 1670 & & & nodularius \\
\hline kalapos & 103 & & & pileator \\
\hline kötélverő & 1579 & & & restio \\
\hline szabó & 1586 & 1606 & & sartores \\
\hline takács & & & & textor \\
\hline \multicolumn{5}{|c|}{ Építők és fafeldogozás } \\
\hline asztalos & 1607 & 1779 & 1846 & mensarius \\
\hline ács & 1818 & & & faber lignarius \\
\hline hüvely- és tokkészítő & 1730 & & & vaginarius \\
\hline kádár, bodnár & 1601 & & & vietor \\
\hline bognár, kerekes & 1607 & & & rotarius \\
\hline kőműves & 1817 & $?$ & & lapicida \\
\hline \multicolumn{5}{|c|}{ Agyag nyersanyag feldolgozása } \\
\hline fazekas & 1616 & 1572 & 1649 & figulus \\
\hline \multicolumn{5}{|c|}{ Szolgáltatások } \\
\hline borbély & 1591 & & & chyrurgus \\
\hline \multicolumn{5}{|c|}{ Csont, szarv feldolgozása } \\
\hline fésűs & 1783 & 1779 & & pectenarius \\
\hline \multicolumn{5}{|c|}{ Egyéb } \\
\hline kalmár-boltos & & 1683 & & mercator \\
\hline kalandosok (Boldogasszony céh) & 1657 & & & \\
\hline szántók, földművesek & 1519 & & & agricolarum \\
\hline
\end{tabular}


nyersanyag beszerzése, a vásárhelyeken az árulóhelyek biztosítása és újak szerzése, a felnövekvő munkaerő képzése, a munkaerő egyenlő elosztása, kontárok megfékezése, -, de nem járult hozzá a műhelyekben folyó munka szervezéséhez.

Az iparügyekkel, pontosabban a céhügyek felügyeletével, intézésével felsőfokon a kancellária foglalkozott. „Iparügyekkel már foglalkozik a kancellária. Ezek legnagyobb részét céhügyek teszik: rendelkezések a céhszabályok betartására, városi céh kiváltságainak védelme a külső mesteremberek ellen, vagy éppen a falusi mesterek, céhek múködésének biztosítása a városi céhekkel szemben, falusi mesterek felvétetése a városi céhekbe, városi mesteremberek közti jogvitákban hozott döntések végrehajtása, céh intése a kiváltságaival járó kötelezettségek ellátására." (Trócsányi 1980.226.)

A kézművesipari termékeket a céhekbe szervezett mesterek és a nekik dolgozó inasok és legények állították elő.

Az udvarhelyi céhek leírására Szeles János, Udvarhely városbírája is kitért várostörténeti munkájában (Szeles-Szájdler 1898. 529534.).

A három székelyföldi céhes városban a céhek századokkal később jöttek létre, ha öszszevetjük a szász városok céheivel, és még nagyobb a lemaradásuk, ha a nyugat-európai céhekkel hasonlítjuk össze őket.

A kézművesek számára a céhtagság nagyon hosszú időn át előnyös volt. A céh biztonságot teremtett, a szervezeten belül is, mert megakadályozta a nagy vagyonok kialakulását, hogy a nyersanyagok és a piacra vihető termékek kisebb csoportok kezében összpontosuljanak, monopolhelyzet kialakulását. $\mathrm{Az}$ inasok és legények egyenlő elosztásával elejét vették annak, hogy egyes mesterek aránytalanul nagyobb jövedelmet realizálja-

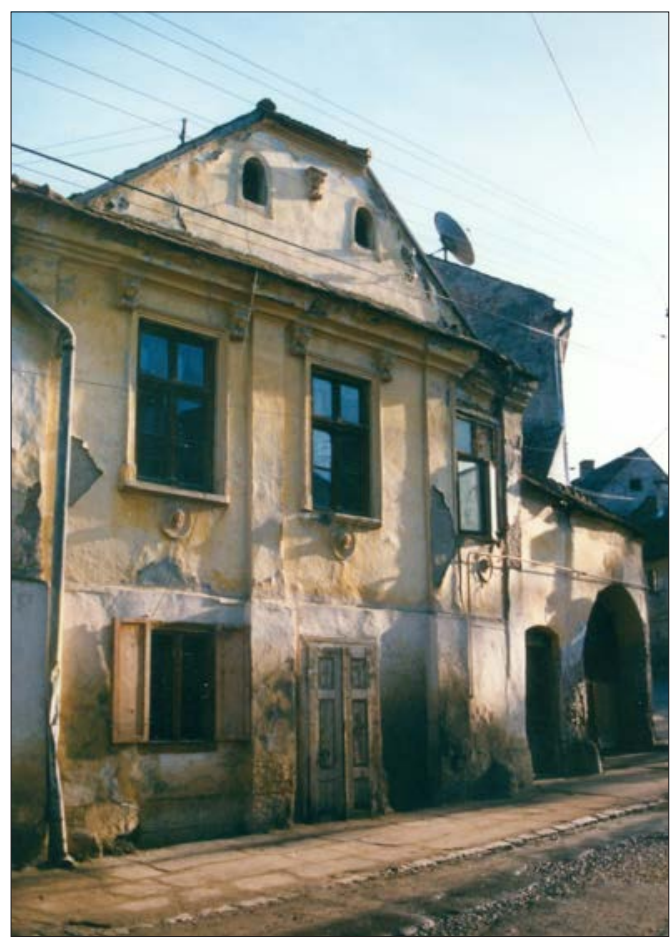

10. kép. Lakóház és mühely a székelyudvarhelyi Szentimre utcában

nak a nagyobb mennyiségű termák előállításának következtében. Joggal megállapíthatjuk, hogy céheink később jöttek létre, mint a hasonló német, francia, angol intézmények vagy akár az erdélyi szász céhek. Azonban a helyi társadalom fejlődése is elmaradott volt. A céhek összhangban voltak a társadalom fejlődésével. Késői megszüntetésük (1872) összefügött a társadalom állapotával, amely 1848-ig, sőt bízvást mondhatjuk, hogy a 19. század végéig hurcolta magával a feudális rendi társadalom örökségét.

A Maros völgyében települt Marosvásárhelynek volt a Székelyföld települései között legelőnyösebb a földrajzi fekvése. Legkorábban itt láthatók a városiasodás jelei. Mátyás király privilégiumai (három országos sokadalom tartására adott vásárjogot), majd a 


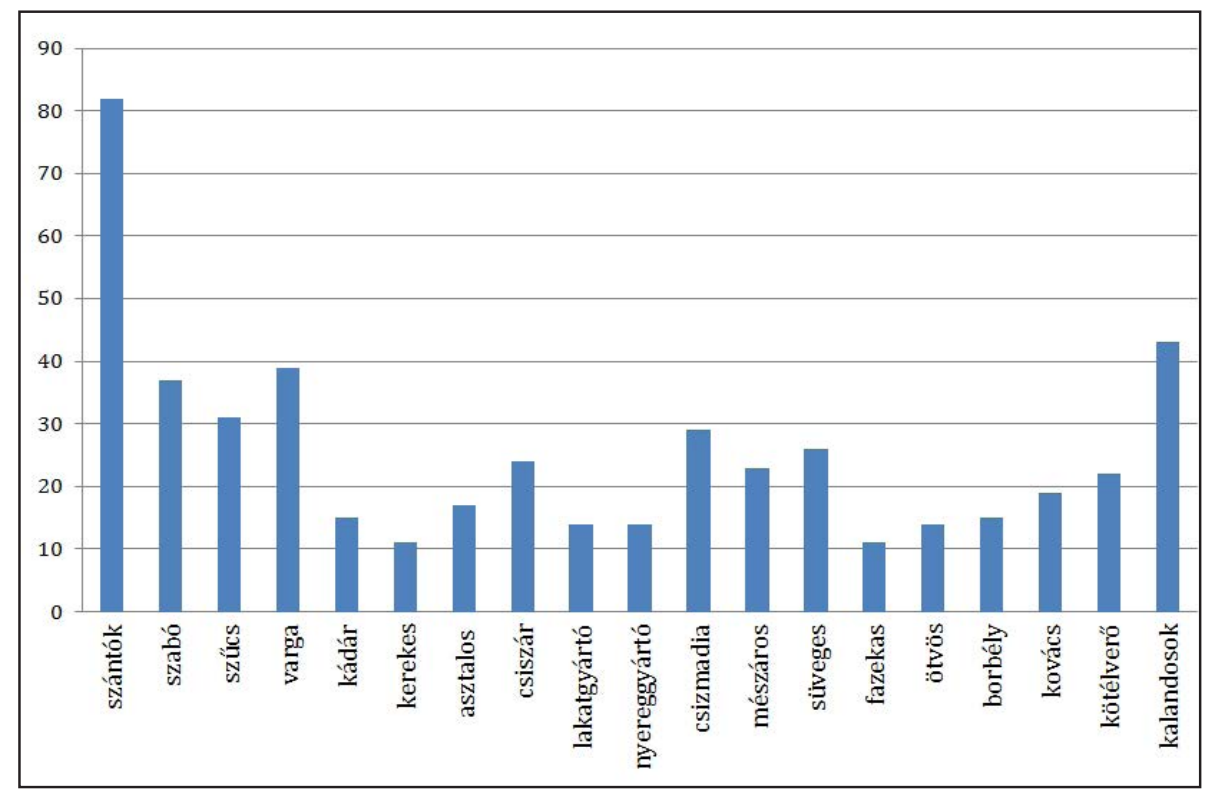

1. ábra. Székelyudvarhely társadalma a 17. században

II. Ulászló, Izabella és János Zsigmond által adományozott kiváltságok előkészítették a mezőváros előrelépését a szabad királyi város rangjára, amit Báthori Gábor fejedelem adományozott 1616-ban. Itt alakult meg az első székelyföldi céh is, amit a mészárosok alapítottak 1493-ban. 1519-ben a szabócéh mellett felsorolták a mészáros-, varga-, szűcs-, kovács-, gyapjúszövő-, takács-, nyerges-, szíjgyártó- és a földművescéheket.

Privilégiumlevelet ${ }^{6}$ a szűcsök 1513-ban, a szíjgyártók 1537-ben, a kötélverők 1579-ben, a lakatgyártók 1581-ben, a tímárok és vargák 1584-ben, a szabók 1586-ban kaptak. A következő században a kádárok-kerekesek és asztalosok közös céhe mellett a csiszárok és pajzskészítők 1615-ben, a fazekasok 1616-ban, a késesek 1629-ben, a csizmadiák 1629-ben és az ötvösök 1632-ben kaptak engedélyt céhalapításra.

A vargák 1607-ben, a szúcsök 1608-ban, a nyereg- és szíjgyártók 1615-ben, a szabók 1620-ban, a lakatgyártók 1653-ban megújít- tatták kiváltságaikat. Céhet alapítottak a borbélyok 1628-ban és a kovácsok 1641-ben. Egy 1657-ben összeállított jegyzék szerint 19 céh dolgozott összesen 486 taggal a városban (Bónis 1997; Paál 2009; Paál 2014).

A 16-17. század fordulója háborúkat, a háborúkkal együtt járó éhínséget, járványokat, a lakosság számának csökkenését hozta magával. A következő években, de legerősebben Bethlen Gábor (1613-1629) és I. Rákóczi György (1630-1652) uralkodásának éveiben a gazdasági élet helyreállt és megélénkült. A fellendülésnek és gyarapodásnak II. Rákóczi György meggondolatlan, véres lengyelországi kalandja vetett véget.

Székelyudvarhelyen 1572-ben a város elöljárói - első ízben a város történetében - elfogadták a fazekasmesterek bemutatott kérését, és statútumot adtak a megalakuló fazekascéhnek. Ezt 1613-ban Báthori Gábor átírta, megerősítette és pergamenre írva újra kiadta. Innen ismerjük a korábbi szövegét, mert az eredeti oklevél elveszett (RNL Fond 249). 
A szokásos latin bevezető rész után következik az 1572-es magyar nyelvű oklevél bemásolt szövege: „My vduarhely biro Zabo Balas, eskwt tarsaival egietemben, ugy mint Zabo Thamas, Zeoch Mate, Zabo Jstvan, Melegh Leörincz. Adgiuk emlekezetre mindeneknek az kiknek illik ez leuelnek rendiben, hogy minekwnkre es faratsagunknak altala engette ez my capitan vrunk Banff? Farkas eo nagysaga, hog? az Vduarheliben lakozo fazakas mestereknek tudni illik Fazakas Peter, Fazakas Janos, Fazakas András, Fazakas Ambrus, Fazakas Pall es Fazakas Balasnak ceh leuelet adnank es eö keozeotteok rendet szabnánk. My annak okaert az keozeonseges igassagot megh gondoluan es egieb uarosoknak priuilegiumat es rendtartasat megh tartuan, teottwnk illien vegezest."
Ezután következnek az első udvarhelyi céhstatútum pontjai (átírt szöveg):

„Először. Mikor idegen mester ide, az városra be jön, mívelésnek okáért, addig az mühöz ne foghasson akaratuk ellen az céh mestereknek és a fazakas mestereknek, hanem négy forintot adjon a céhbe, kétszer tiszteljen. Az elsó tisztelés legyen öt tál étek, egy pecsenye, négy veder bor, cipó, kalács elég. A második tisztelés legyen hat tál étek, pecsenye, cipó, kalács elég és hat veder bor.

Másodszor. Ha mely idegen mester az levelet magyaráztatni akarja el nem hivén a mesterek szavát, egy forintot tegyen le, a levelet úgy magyaráztathassa meg.

Harmadszor. Ha valamely ifjú mester a városra bejön, esztendőnél és három napnál tovább ne legyen szabad mívelni, tisztelettel tar-

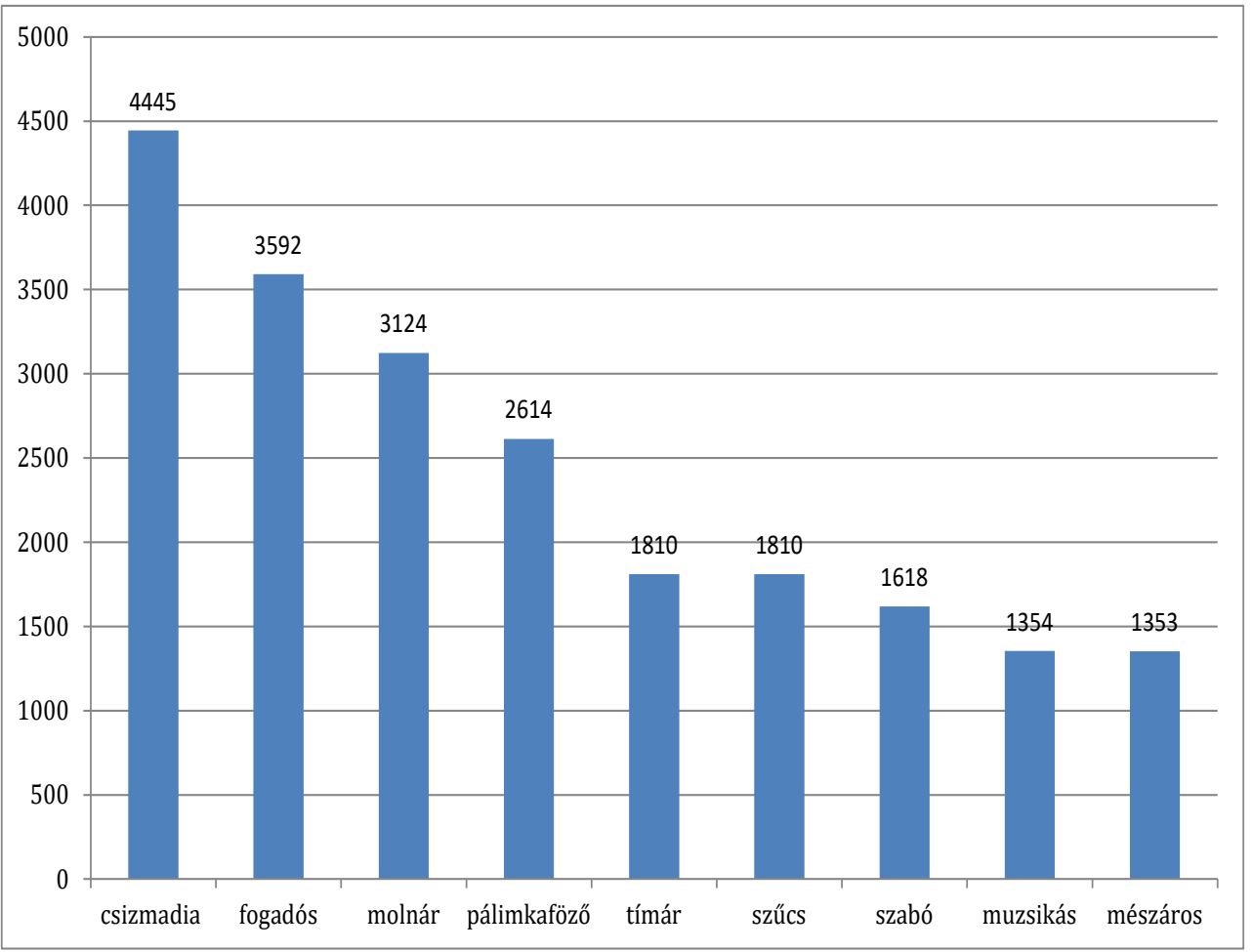

2. ábra. Kézmúvesmesterek a Székelyföldön a 17. században 
tozzék. Ha pedig ismét az városból kimegyen, három napnál és esztendőnél tovább mulat, ha megjön, tisztelettel tartozzék, addig ne legyen szabad mívelni.

Negyedszer. Ha valamely legény be jö, senki a céhmesterek híre nélkül, müvet neki ne adjon.

Ötödször. Ha valamelyik céhbeli mesternek fiai az atyán kívül mesterséget akar tartani kétszeri tiszteléssel és egy, tartozzék és egy font viasszal a céh ládájába.

Hatodszor. Ha valamely idegen mester a céhbe jön, és mester leányát, avagy céhbeli mesternét veszi, kétszeri tiszteléssel tartozzék és két forinttal."

A város elöljárói nem állítottak akadályokat a céhalapítás útjába, de annál nehezebb volt elnyerni az 1562 után épült fejedelmi vár és birtokközpont kapitányának, Bánffy Farkasnak az engedélyét. A 16. század második felére már nagyon jól kialakultak a céhszabályzatok (privilégiumok) formai és tartalmi jegyei. A legkorábbi ismert szabályzatot 1376. november 9-én adták ki Nagyszebenben az erdélyi hét szász szék öregbírái (Kovách Géza - Binder Pál 1981. 57-65).

Jellemző, hogy a 16. században a fazekasok céhe mellett megalakuló három másik céh a bőrfeldolgozó szakmákat képviselte, ezek később is a legerősebbek és legnépesebbek voltak a városban. ${ }^{7}$

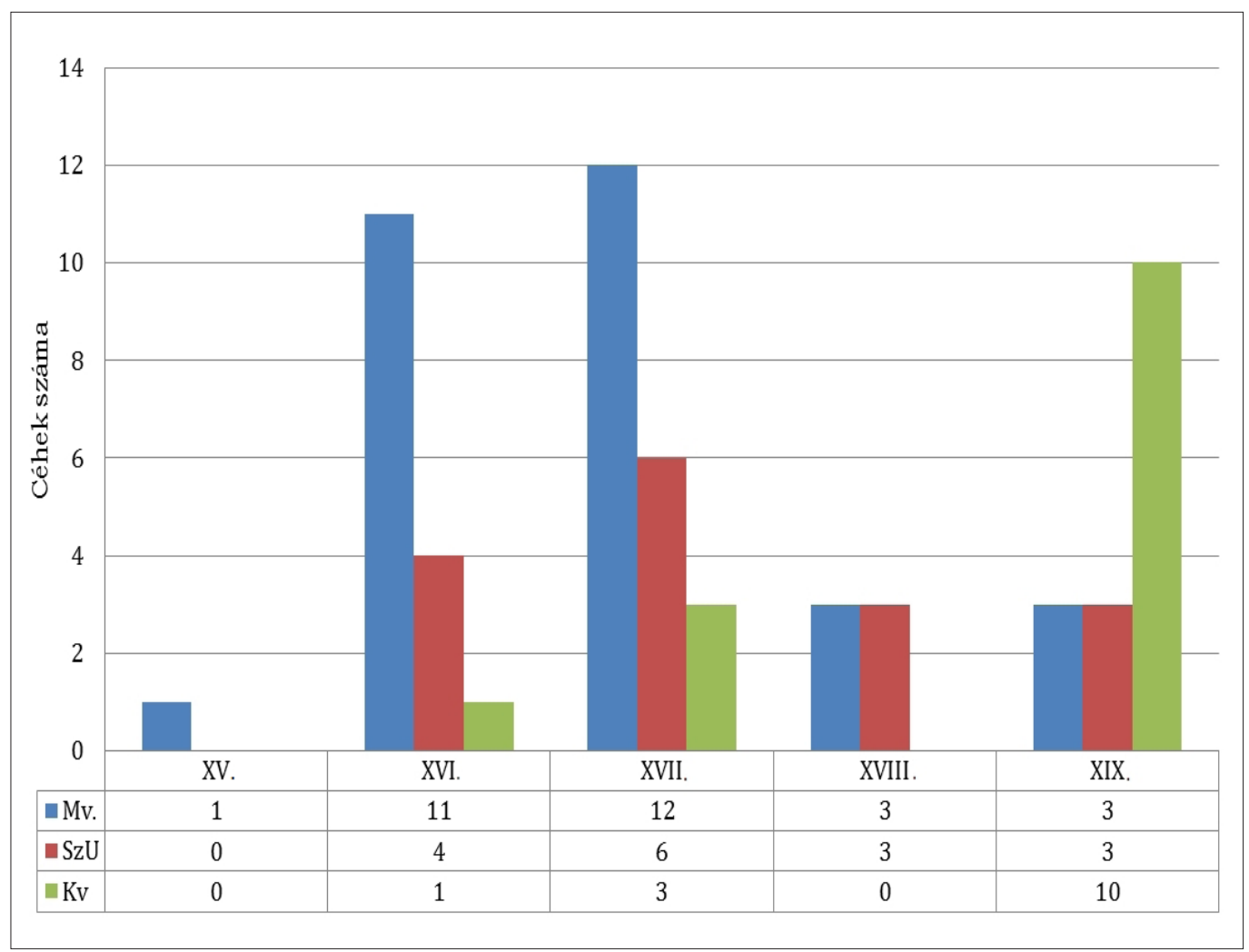

3. ábra. A székelyföldi céhalapítások századokra bontva (Mv = Marosvásárhely; SzU = Székelyudvarhely; Kv = Kézdivásárhely) 


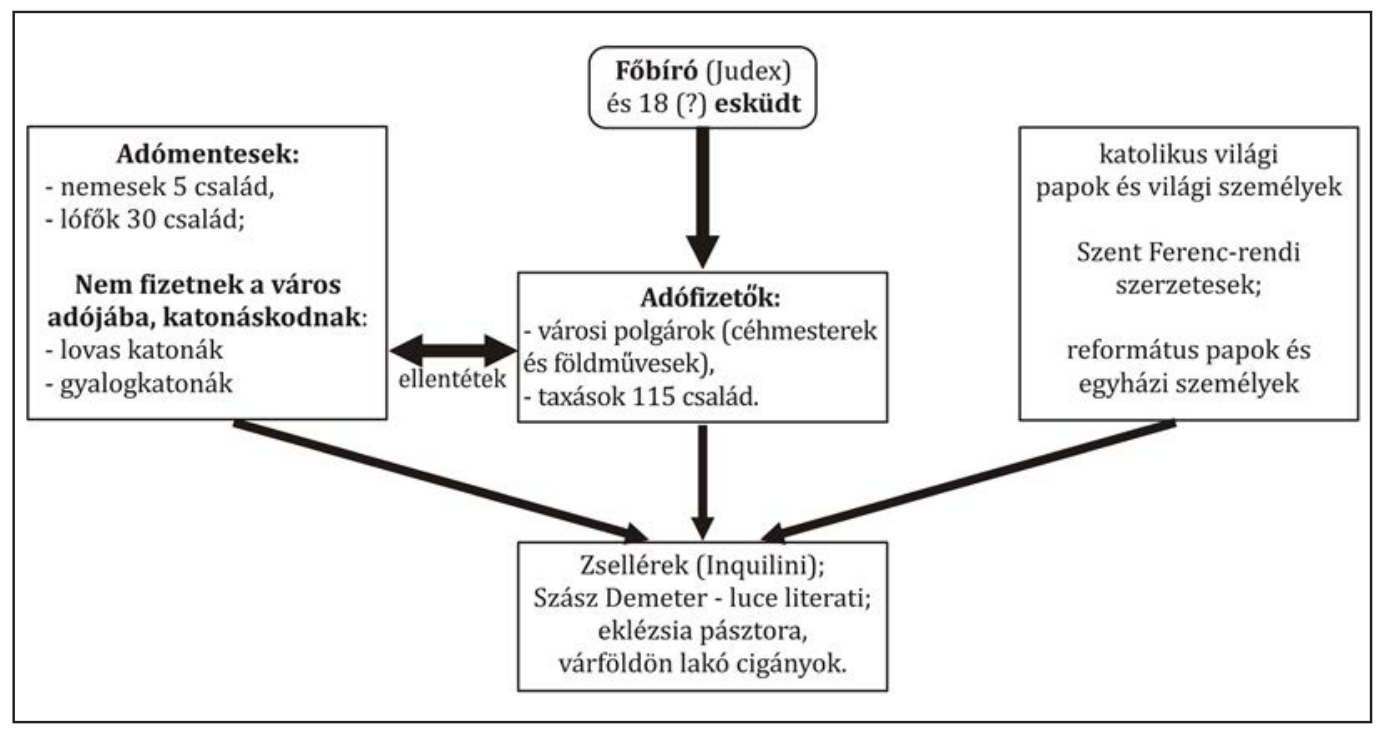

4. ábra. Székelyudvarhely társadalma a 17. században

\section{A székelyudvarhelyi céhek (megalakulásuk időrendjében)}

16. század:

fazekascéh (1572),

vargacéh (1577),

szűcsök céhe (1579),

tímárok és vargák közös céhe (1584).

17. század:

szűcs-szabó közös céh (1606),

lakatos-csiszár (1613),

szabók (1628),

mészáros (1630),

csizmadia (1635),

kalmár, boltos (1683).

18. század:

asztalos (1779),

szíjgyártó (1779),

fésűs (1779).

19. század:

kalapos (1803),

kordoványos (1819),

cipész (1863).

\section{A kézdivásárhelyi céhek (megalakulásuk időrendjében)}

16. század:

tímár (1572).

17. század:

csizmadia (1638),

fazekasok (1649),

szűcsök (1649).

19. század:

mészárosok (1809),

kalaposok (1844),

szabó (1841),

kovács-lakatos-pléhes (1844),

asztalos (1844),

üstgyártó (1844),

kalapos (1844).

Számszerűen is a 17-18. században alakult a legtöbb céh Székelyföldön, de nem tévedünk, ha állítjuk, hogy ezek az évszázadok voltak a céhek működésének legjelentősebb századai a régióban. 
A céhalapítást a Werbőczy István törvénykönyvében, a Tripartitumban megfogalmazott jogszabály tette lehetővé, amely megengedte a statútumok (rendszabályok) alkotását: „És ilyen módon a szabad városok is, nemkülönben saját céhükben és maguk között a kereskedôk, kalmárok, szabók, szücsök, vargák, tímárok, és más mesteremberek is a fejedelem megegyezésének hozzájárulásával statútumokat (rendszabályokat) hozhatnak. Csakhogy ezek igazságosak és tisztességesek legyenek, mások jogaiban és szabadságában kárt ne tegyenek, és sérelmet ne okozzanak. De ezek miképpen előadám, csakis közöttük állnak meg és maradnak erőben." (Werbőczi 1514) Ez volt a jogi alapja a székely falutörvényeknek, a városi önkormányzatoknak. A céhes mesterek jogai törvénybe voltak foglalva: „Mives embereknek privilegiumiról. Mindenféle míves embereknek privilegiumok ezekkel a generalis conditiokkal [általános feltételekkel] tartatnak meg és hagyatnak helyben. Elsőben, hogy jó mivet miveljenek. Másodszor, hogy a várost és vidékét mindenek neme szerént való mivekből, vagy mivelt materiakból meg ne fogyatkoztassák, s az eddig való abusus [visszaélés] szerént külső helyekre s néha országokra is hordván, a hazában ne szerezzenek szükséget, holott a székeken kívül lévőket el rekesztik, kik az olyant megbővitenék, $s$ magok is pedig nem satisfaciálnak [eleget tesznek] hivataljoknak. Harmadszor, hogy az időknek mivoltához képest lett s leendő limitaciokat observalják." (Approbata Constitutiok III. R. Titulus LXXXV.)

\section{Limitációk}

A számtalan feudális privilégium meganynyi akadálya volt a termékek szabad áramlásának, adás-vételének. A megkötések csak lassan oldódtak fel. Az állam is beavatkozott a gazdasági élet bonyolult gépezetébe. Leg- többször gazdaságon kívüli eszközökkel, rendeletekkel, határozatokkal akartak segíteni, elérni a lakosság boldogulását. Ebbe a sok évszázados folyamatba illeszkedett be a - nyugat-európai színvonaltól gazdaságilag is elmaradt - Erdélyi Fejedelemség fennállásának éveiben (1541-1690). „Az általános európai fellendülés függvényében Erdélyben is megfigyelhetö valaminő olyan növekedési tendencia, amely, ha nem is jelzi a termelési viszonyok forradalmasodását, tanúsítja a termelőerők körének kiszélesedését, különösképpen a mezőgazdaságban. $S$ ha nem is ígéri a nyugathoz való ugrásszerü felzárkózást, megcsillogtatja az iparivárosi-polgári felemelkedés biztató jövőbeli lehetôségeit" - állapította meg Imreh István, aki a kérdés legjobb ismerője volt (Imreh 1999).

A céhek saját bevételeik gyarapítására előszeretettel emelték kész termékeik árait. Ilyen esetben az országgyúlés által megszavazott limitációkba ütköztek. A korszakban is állandósult az ellentét egyfelől a városi céhek, másfelől a piac szabályozására törekedő fejedelem, a kincstár és országgyűlés között. A fejedelem, az állam következetesen, de annál kevesebb eredménnyel igyekezett céljait (a minél nagyobb bevételek megszerzését) érvényesíteni.

A céheket alapító és működtető mesterek, a várost fenntartó és az állami adót fizető „adóalanyokat" a városi polgárjoggal rendelkező taxások között kereshetjük.

\section{A limitációk a céhek életében}

Az állami beavatkozás legáltalánosabb eszközei az ún. árszabályozások vagy limitációk voltak. Nem túlzás, ha azt állítjuk, hogy a céhek számára ezek jelentették a legnagyobb megkötést, akadályt. A limitáció a kötelező piaci árszabást, az árak szabályozását, legtöbbször az árak vagy a bérek vagy mind- 
kettő maximalizálását jelentette. Talán igazságtalanok voltak a céhekkel a kortársak, mikor a limitációk rendszerét is a céheknek tulajdonították. Ezeket végül is nem a céhek kérték és dolgozták ki, hanem a felsőbb hatóságok állították össze és „varrták a céhek nyakába". Ezzel a kérdéssel is foglalkozott a fejedelmi kancellária, majd később a Gubernium, a Főkormányszék. A fejedelemség korában az árszabályozásra vonatkozó „limitációkat" az országgyúlés fogadta el és adta ki. Bethlen Gábor uralkodása éveiben rövid ideig egy külön felügyelőség ellenőrizte. Ezt az 1624. június-júliusi országgyűlés hozta létre az V. tc. alapján, és Kamuthy Balázst nevezték ki vezetőjéül. Hatáskörét az 1625. évi árszabás írta le. 1627-ben ezt a feladatot a három nemzet egy-egy képviselője látta el (Trócsányi 1980. 319-320.).

A fejedelemség korának kezdetén, már János Zsigmond uralkodásának éveiben megjelentek az első jelei az állami beavatkozásnak a gazdasági életben. Az 1566. augusztusi országgyűlés elrendelte, hogy ellenőrizzék a kézműveseket, hogy az árszabás szerint áruljanak a vásárokban.

A limitáció terminus legkorábbi előfordulását erdélyi magyar szövegben 1589-ben találjuk (Szabó T. Attila 1995. 1162-1163.). „Limitálni” az árak megszabását, maximalizálását jelentette. A piacon eladott, megvásárolt termékeken kívül a munkabért is limitálták. Az árak rendeletekkel való szabályozása a gazdasági élet gyengeségének, betegségének a szimptómája. Későbbi korokban is gyakran kísérleteztek ilyen és hasonló módszerekkel, de ez mindannyiszor kudarcot vallott. A gazdasági életbe beavatkozni gazdaságon kívüli eszközökkel eleve kudarcra van ítélve. Az első udvarhelyi céhek alapítását megelőzően már életbe léptek az első szabályozások. Az 1556. évi országgyű- lés elrendelte, hogy a városok elöljárói ellenőrizzék vásáraikon a kézművesek által megállapított árakat. Megtiltották, hogy lovakat, bőrárut, sarukat külföldre eladjanak. Még ugyanabban az évben a kolozsvári országgyúlés latin nyelven szerkesztett limitációt léptetett életbe. A limitált árak nemcsak a céhes mesterekre voltak kötelezők. 1560-ban elfogadták a szászok által előterjesztett árszabást, és előírták, hogy a nemesek házainál dolgozó jobbágyok is tartsák be. A büntetést azok számára, akik nem tartották be az előírt árakat, 200 forintban állapították meg, ami hatalmas összeget jelentett. Az 1572-ben készült limitáció 1592-ig maradt érvényben. Ugyanakkor (1593) könnyítettek a vándor céhlegények terhein, akik be- vagy kiutaztak a fejedelemségből.

1578-ban a drágaság mérséklésére újra a kivitel megszorításával próbálkoztak. 1585ben megtiltották az arany (vert és porarany) kivitelét, megtiltották, hogy „velencei marhával" [ékszerek] kereskedjenek, hogy a nemesfémeket kivigyék (Approbata Constitutiok II, R. Titulus XIV. art. I-IV.).

A fejedelemség kori gazdaságpolitikának nem volt elméleti alapja. 1588-ban a szabad kereskedelemben látják a gyógyírt a drágaságra: „nem a szük, hanem a bő marha [itt mindenféle áru] teszen olcsóságot". De már 1591-ben határozatot hoztak a külföldi kereskedők kitiltásáról (Szádeczky 1913. 59.).

„Bethlen a merkantilizmus szellemében a termelőket és kereskedőket pénzszerzésre ösztökélte, támogatta és fellendítette a bányászatot, a kézmúvesipart, manufakturákat létesített, ugyanakkor biztosította a vagyoni és szellemi biztonságot." (Csetri 1999) Bethlen Gábor, Erdély legeredményesebben gazdálkodó fejedelme is használta a kereskedelemben gazdát cserélő termékek árának szabályozását az áremelkedések, az infláció 
megfékezésére. Gyakorlatban folytatott gazdaságpolitikája a korai merkantilizmus eszmekörébe illeszthető. Nem volt tudatosan kidolgozott elmélete Erdélyben, de a fejedelem gyorsan felismerte, hogy keveset vásárolni, többet eladni, vagy külföldi viszonylatban is a pozitív mérleg az előnyös. „Bethlen uralkodásának tizenhat esztendeje volt az erdélyi fejedelemség történetének legfényesebb korszaka. Bár mindenkinél erösebben hangoztatta, hogy akarata a törvények felett áll (princeps absolutus), alattvalóinak sem volt oka panaszkodni rá. Erdély földjét 1616 óta nem érte külső támadás, [...]. Az újjáépítés és a gyarapodás rohamléptekben haladt elöre, $s$ bár java hasznát a kereskedelmi és más monopóliumokon keresztül maga a kincstár fölözte le, kihatott a társadalom egészére." (Szakály 1990. 217.)

Bethlen Gábor uralkodásának éveiben háromszor volt kénytelen limitációt megszavaztatni az országgyúléssel.

Az 1622. évi kolozsvári országgyúlés törvényeinek X. articulusában a kézműveseket vádolták, amiért nem tartották be az országos limitációban meghatározott árakat, ezért kérik azok szigorúbb betartatását. ${ }^{8} \mathrm{Az}$ ispánokra és városi bírákra, akik elnézték a limitátió megszegését, 200 forint büntetést is kiszabhattak. ${ }^{9}$

Két évvel később, az 1624. június 24-ijúlius 8-i gyulafehérvári országgyúlésen megszavazott V. articulus „Az mesterembereknek és egyéb kereskedô rendeknek is mívek s árújok limitációjárúl, az limitatio ellen tusakodóknak poenajok, annak exigálásáról, és az kedvezőnek büntetéséről" - továbbra is a mesteremberekre panaszkodott, akik magas árakat kérnek, annak ellenére, hogy a bőröket olcsón vásárolhatják meg. Ha a városbírák a kötelező árakat nem tartatják be, büntetésük legyen 500 (!) forint. A büntetés ilyen nagyfokú emeléséből arra következtethetünk, hogy a korábbi szigorúság, a büntetés nagysága nem volt eléggé elrettentő, nem javított a helyzeten.

„Az úri és nemes rendek a várasbeliek ellen panaszolkodnak, hogy eladásnak okáért beküldött marhájok az piacon szabadoson el nem adhatják, nemességnek nagy praejudiciumára, kiről hogy felsége kegyelmesen providealjon, supplicalnak." Tehát az 1622. május 1-23-i kolozsvári országgyúlésen a vármegyei nemesek panaszkodtak a városiakra, a kézművesekre, mert az alacsony árakért nem tudják eladni „marhájok”-at. ${ }^{10}$ Sok kézműves kétszer kockáztatta szerény jövedelmét a piacon, egyszer amikor megvette a munkájához szükséges nyersanyagot (pl. a tímárok, kordovánosok a mészárosoktól vásárolták a nyers bőröket, és feldolgozásuk után továbbadták a csizmadiáknak, a cipészeknek.), majd munkájával új értéket adva hozzá a piacra vitte.

A XXIII. art. az új keresztényeknek (anabaptisták) biztosított engedményeket. „Az új keresztyének is, kik most itt benn vadnak és ezután és bejönnek ő felsége engedelméből, az minemú helyet és szabadságot ô felsége adott nekik, a statusok is annak consenciálnak és confirmálják articulusokban." ${ }^{11} \mathrm{Ha}$ nem értjük is az első pillanatban, úgy tűnik, hogy nem illik Bethlen Gábor ipart támogató politikájába az anabaptisták behívása és letelepítése Erdélyben, de csakhamar felismerhető az a szándék, hogy a fejlettebb technikai szinten dolgozó és jobb munkaerkölcsöt hozó csoport a hazai ipar fejlődését szolgálja. Ugyanilyen meggondolásból adott letelepedési engedélyt a zsidóknak. ${ }^{12}$

Az országos intézkedések ellenére az árak folytonosan növekedtek. „A hosszabb távon meghatározott árváltozási indexek valóban nagymértékü emelkedést tanúsítanak. Az erdélyi limitációk alapján az iparcikkek (arany- 
A di udvarhely városi Fö Biro eḟeles Mártojn. Eshüti Polgárok eżeles András, Daroczi Ferenzz Kolos

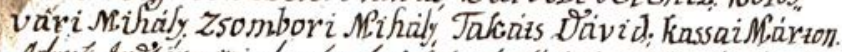

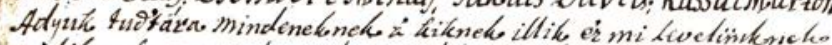

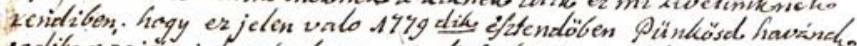

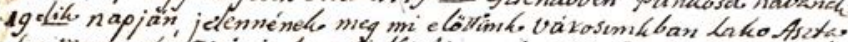

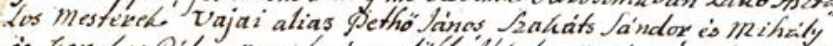

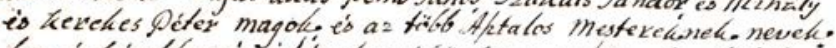

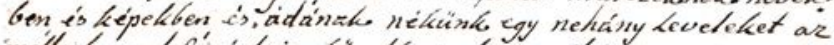

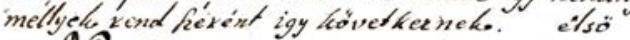

Mos Sabriet tei

Mos Sabriel Deigration Transyluamie. Valachie. Trans,

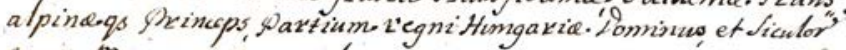
comes. Memovia. Commendamus tenore mos entium, rignificantes

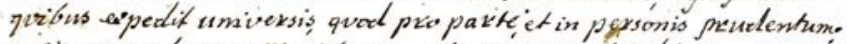

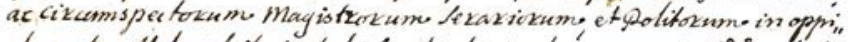

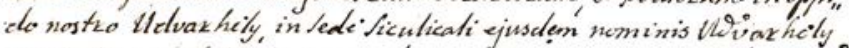

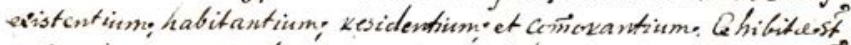

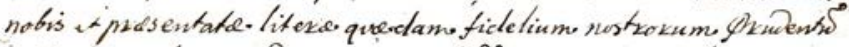

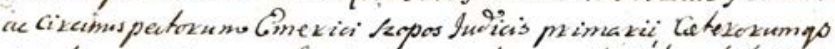

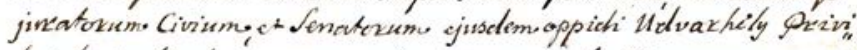

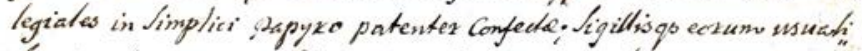

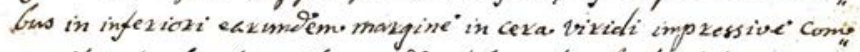

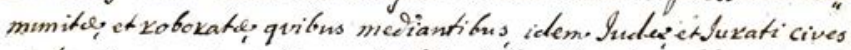

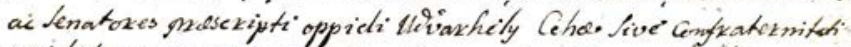

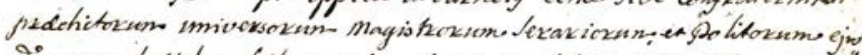

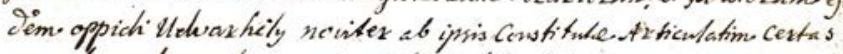

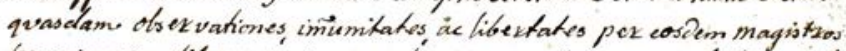

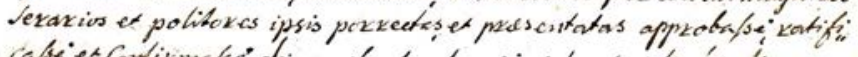

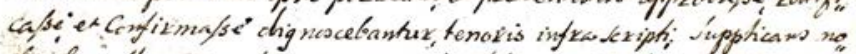

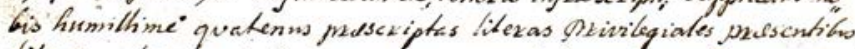

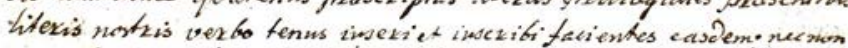

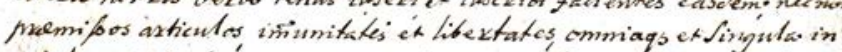

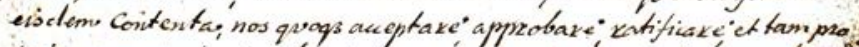

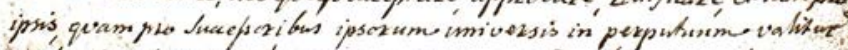

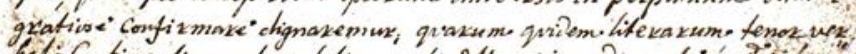

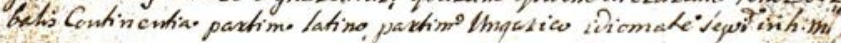

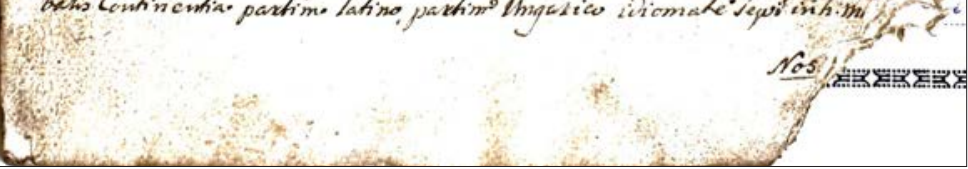

11. kép. A lakatoscéh leveleinek másolata (CL. 953)

forintra átszámított) százalékszámai a következő arányokat tükrözik...” (Imreh 1999. 72; Imreh 1979. 169-198.)

1556-1560 között az árak 10-20\% növekedést értek el (Szádeczky Lajos 1913. 52.), vagyis ennyit romlottak.

\section{3. táblázat.}

\begin{tabular}{|l|c|c|c|}
\hline \multicolumn{1}{|c|}{ Év } & $\mathbf{1 5 7 1}$ & $\mathbf{1 6 0 9}$ & $\mathbf{1 6 2 5}$ \\
\hline iparcikk [\%] & 100 & 150 & 197 \\
\hline bor [\%] & 100 & 158,8 & 200 \\
\hline
\end{tabular}




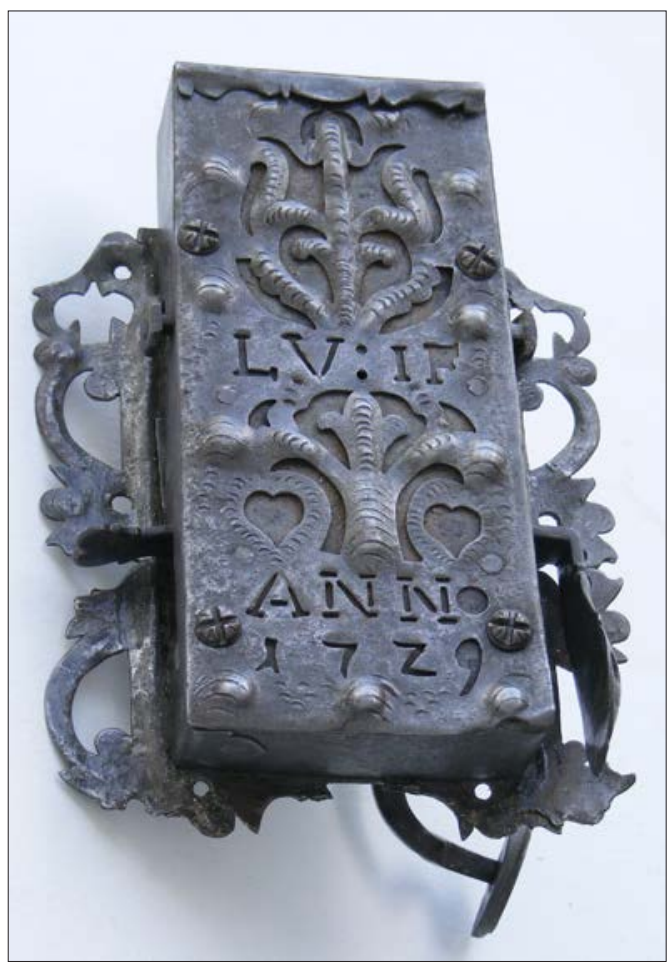

12. kép. 1729-ben készült székelyudvarhelyi ajtózár

A 17. század első évtizedeiben négy országos, az Erdélyi Fejedelemség területén hatályos limitációt szavazott meg az országgyűlés. Az elsőt 1608. június 23-án (EOE. VI. 132-157.). Ezeken kívül még a megyék és székek vagy a városok is adtak ki helyi viszonylatban érvényes árjegyzéket.

Az 1625. májusi gyulafehérvári országgyülés a termékek limitált árainak új jegyzékét fogadta el. Az ármegállapítás szövege a mészárosmesterekkel kezdődik mint a lakosság élelmezésében fontos szerepet betöltő mesterséggel és úgy is mint a bőrt feldolgozó mestereket nyersanyaggal ellátó iparral. „Az mészáros mesterek dolgát megértettük volna az városbeli fönépektól mindenütt valóktúl, így szóltunk hozzája, hogy az városbeli polgármesterek és királybírák, minden városo-

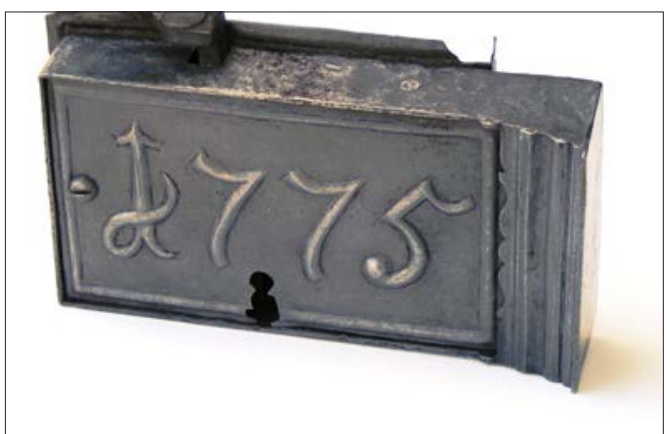

13. kép. 1775-ben készült székelyudvarhelyi ajtózár

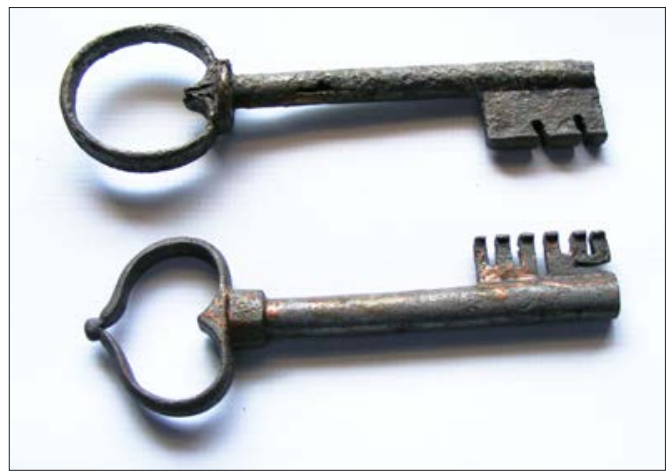

14. kép. Ajtózárkulcsok

kon az baromnak kivételéjért, olcsó-, avagy drágaság ha lenne, jó gondviseléssel hozzálássanak, hogy az szerint képes árán adják el a húst, melyet ők is minden nap pénzen vesznek, ő magokért úgy rendeljék az húsnak fontját adni egyebeknek is hogy az szegény község is meg ne nyomorodjék miatta: sőt ha valami új nép jönne valamely városra, akkoron is ne adassék drágábban a húst, szinte mint annak elôtte. Az falukon is azon mód observáltassék." A limitáció rögzítette az állatárakat, melyek között a szarvasmarhaárak voltak a legfontosabbak, a hús kiskereskedelmi árát és a bőr, szaru, csont árait. A mészárosok a borjúhúst igen drágán, „font nélkül” adták el. Ha marhát vásárolt a mészáros, köteles volt azt kimérni. A mészáros „nem tôsér, hogy az marhát lábon adja". Ha rajtakapták, hogy lábán adta 
tovább a nyúzni való marhát, vegyék el attól, aki megvette, és a mészáros is fizesse meg a marha árát. Ha pedig nem vágtak eleget, de volt elég vágómarha, "ha vagyon barma, mészárszékrevaló”, zárják ki a céhből, „a céhből kivettessék, soha többet mészárosságával, se tôserséggel, se céhigazságával ne élhessen". Nem követelhet a mészáros "kupa bort” vagy más ajándékot. Tilos hamis fonttal mérni, ennek büntetése „pénze, tisztessége, marhája elvesztése". Falura is a városból vigyenek pecsétes réz- vagy vasfontokat, húsnak valókat. A falun dolgozó mészárosok úgy áruljanak, mint a közeli városban teszik, „hamis fonttal, kővel, sohul senki pénze, tisztessége, marhája elvesztése alatt, ne merjen, hanem városokról vigyenek pecsétes réz, vagy vas fontokat, húsnak valókat, kivel mérjenek, igaz serpenyőjük legyen mindennek, az falusi bírák ezekre jól vigyázzanak tisztek elvesztése alatt" (EOE. VIII. 273.).

Majd a munkamenet sorrendjében előírták, hogy „az tímároktól miképpen adják bőröket az varga-és szígyártó mestereknek és az kik az ő bőrökbőll [bőreikből] mívelnek". Majd logikai sorrendben „az vargamesterekról miképpen adják el az sarukat" következett.

A csizmadiák is a tímároktól vásárolt kikészített bőrökből dolgoztak. A limitáció 52 féle csizmadiaterméket sorolt fel. Legdrágább volt az „[e]z országban csinált törökországi szép és jó karmazsin csizma, öregembernek való", aminek három forint az ára. Ugyanenynyit ért egy kidolgozott „öreg” ökörbőr is.

Ezután a szíjgyártótermékek következtek. A hámok és a szíjak sokasága fejlett nagyállattartásról tanúskodik.

Következtek a szűcsök, a kerekesmesterek, a csapók, a szűrcsináló szabók, a nemezcsinálók, a szőrmívesek, kik lasnakot, harisnyát, condorát, gubát, csuklyát, pokrócot csinálnak.

A szabók rendelésre 22 féle divatos ruhadarabot szabtak és varrtak.
A pajzs- és kopjagyártók „Egy jó szegődött merő kopját, melyen három gyantár vagyon, adják harminc pénzen. Egy fuallott kopját, jó temérdeket, hatvan pénzen. Az ki ezeknél jobbakat, szebbeket akar csináltatni, alkudjék a mesterrel."

A szappanfőzök egyféle terméket árulhattak, aminek fontja 12 pénz volt. A nyergesek egy jó nyerget, „két kápájút, itt való cseres bőrből, veres vagy fejér bőrből" ugyancsak 3 forintért adhattak. A lóbőröket csak a pajzs- és nyereggyártók használhatták fel.

A vas-árosok az erdélyi és magyarországi hámorok termékeit juttatták el a vásárokra.

A kovácsok „egy jó öreg, erôs patkót, a maga vasából" 9 pénzér vertek fel. Legtöbb munkájuk a patkolás és a szekérvasalás és javítás volt. A kapa lehetett toróckói, medgyesi, besztercei vagy segesvári.

$\mathrm{Az}$ ötvösök számára meghatározták az arany minőségét, amiből dolgozhattak.

A lakatosok „egy kengyelvasat, öreget, szépet, cifrát, nagy pálhást, gombost, szép ónost, szalamiákkal, egy forinton 50 pénz. Annál alábbvalót szépet, szalamiást, 1 forinton 35. Annál is alábbvalót pálhásokat 1 forinton 25 pénzen. Annál is alábbvalót 75 pénzen. Annál is alábbvalót 60 pénzen."

Az ónmíveseknek a nyersanyag drágulása miatt megengedték, hogy hat font fehér ónhoz keverjenek fél font fekete ónt.

A kádárok „igaz mértékre csinálják az ő míveket", és reá vigyázzanak a céhmesterek városon és falun a bírák. A hordók űrtartalmát szigorúan ellenőrizték, mert mindenik egyben mértékegység is volt. „Az öreg hordó nyolcvan vedres legyen igazán. Az földes negyven vedrös legyen. Az egész hordót, ki nyolcvan vedrös, jó, jól csinált, jól kötött, adják 1 forinton 50 pénzen." A kádárok csináltak még boroshordót, kétfülű csebret, lóitató háromvedres csebret, egyvedres kétfülű csebret, 
vízmelegítő kártot, juhfejő vedret, deberkét, öreg szapulló, feredőt, öreg kádat, nyomót vagy káposzta sózni valót, fenyőfából veder, öreg kádkötésűt, lijut, szőlőhordó botot.

A csiszármesterek termékei a hegyes tőr, szablya „az ki paraszt módon vagyon, 1 forintért 53 pénzért”. Egy szablya és egy pallós három forint, volt még demecki szablya és csetneki szablya.

Kőmívesek napibére ellátással 42 pénz. Dolgoztak az építkezéseken még ácsok is.

A zemes csinálók szarvas- és őzbőrt dolgoztak fel.

A téglavetők rakótéglát, pádimentomtéglát, cserepet csináltak.

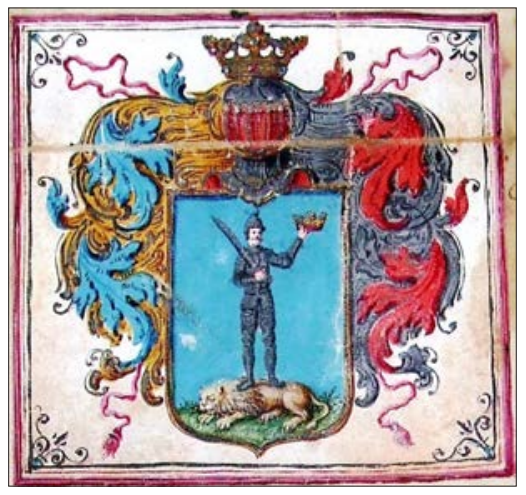

15. kép. Címer az udvarhelyi Ágotha János armálisán. Adományozta II. Rákóczi György 1660. január 13-án Nagyszebenben (Románia Nemzeti Levéltára Hargita megyei Igazgatósága F 249 617. sz.)

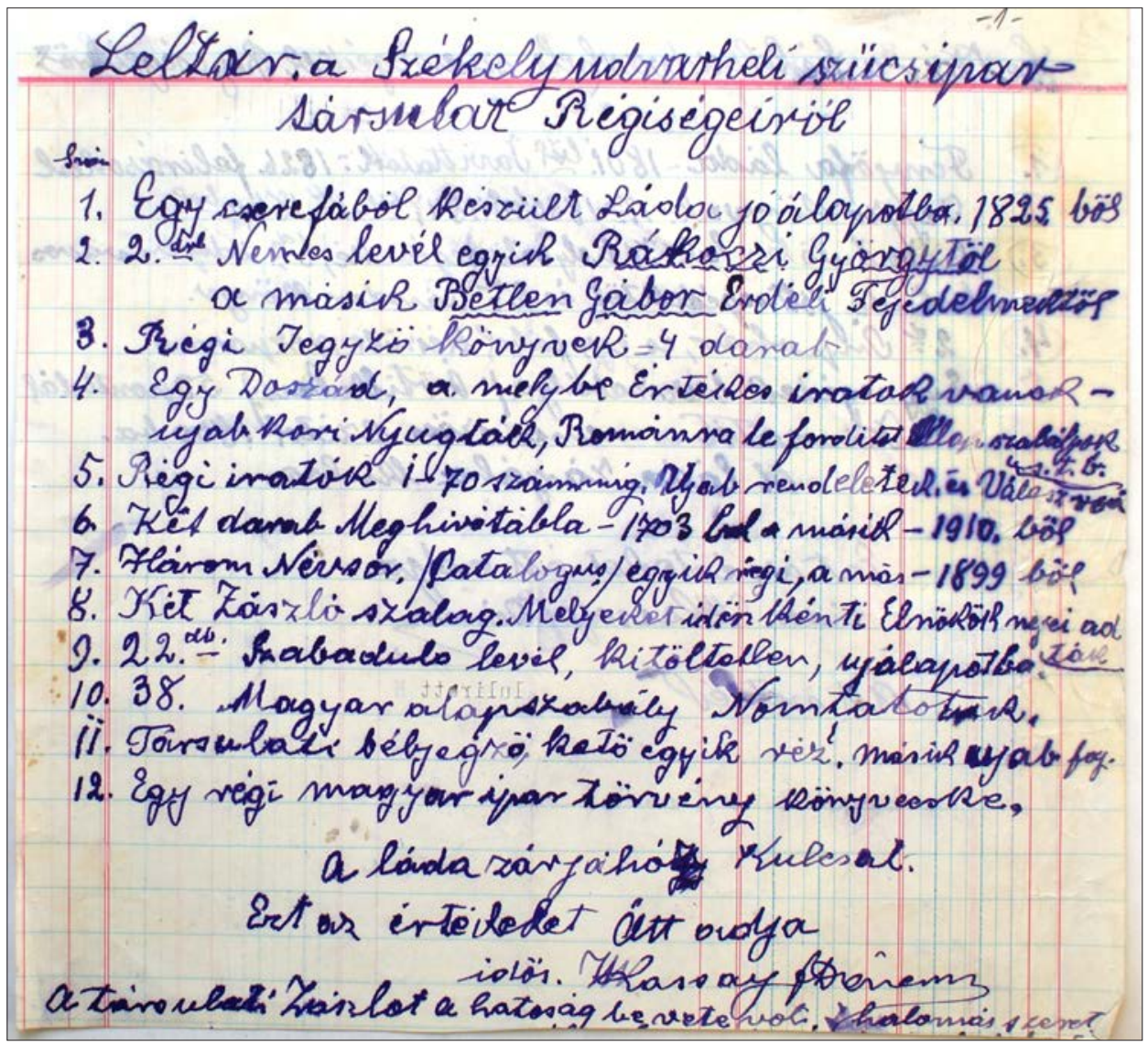

16. kép. A szücs ipartársulat „régiségeinek” leltára 

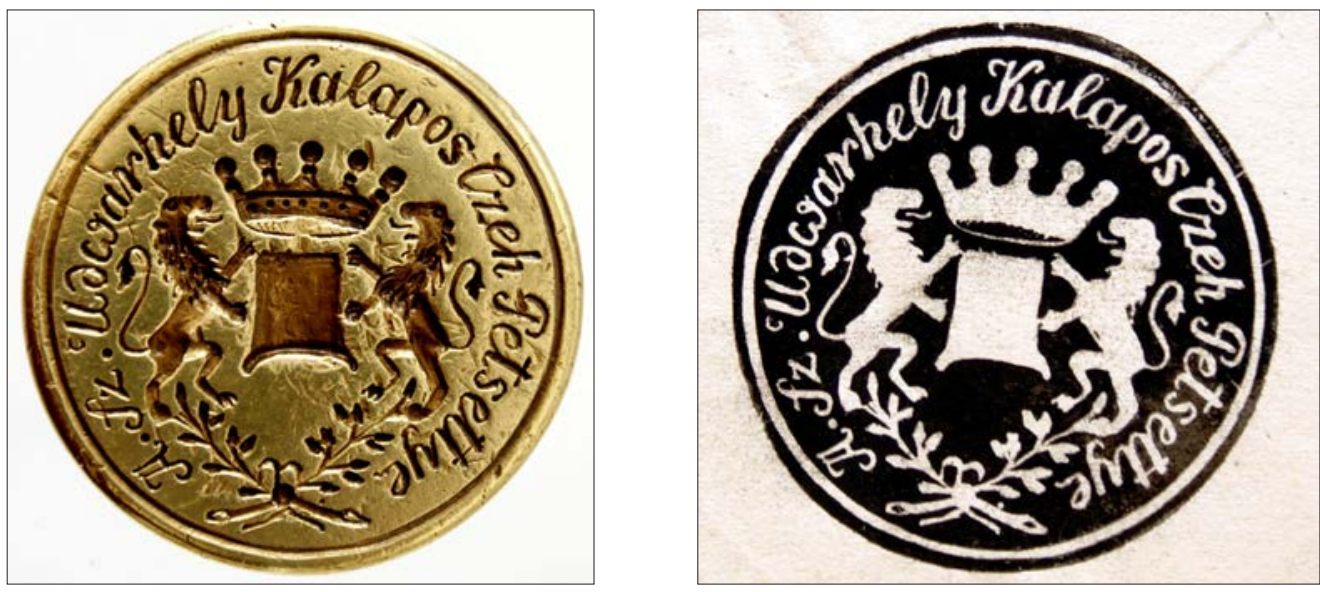

17. kép. Kalaposcéh pecsétje és koromlenyomata

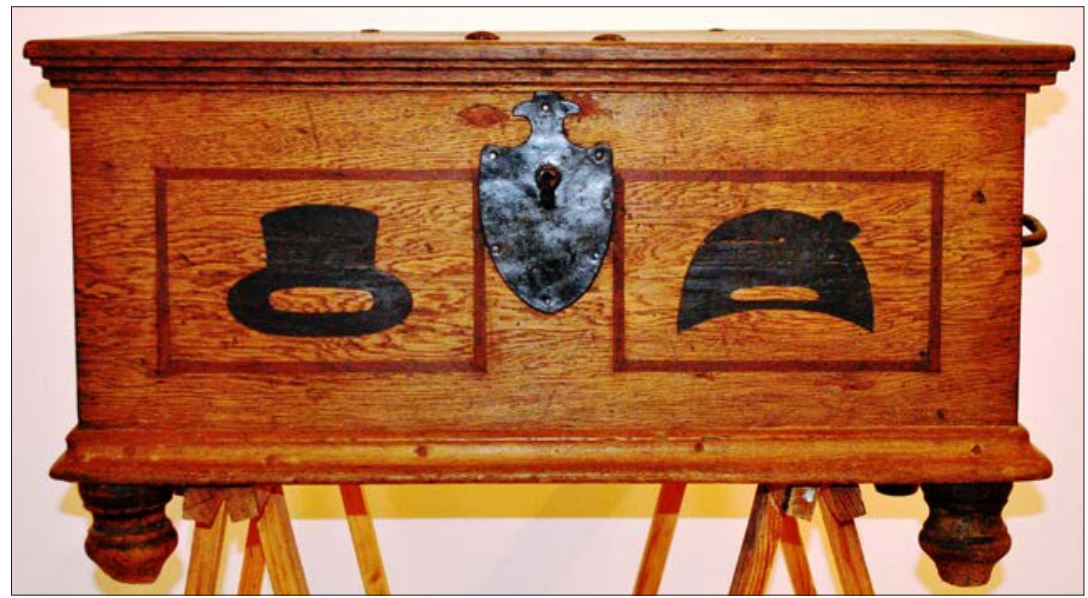

18. kép. Kalapos céhláda, korabeli kalapokkal díszítve

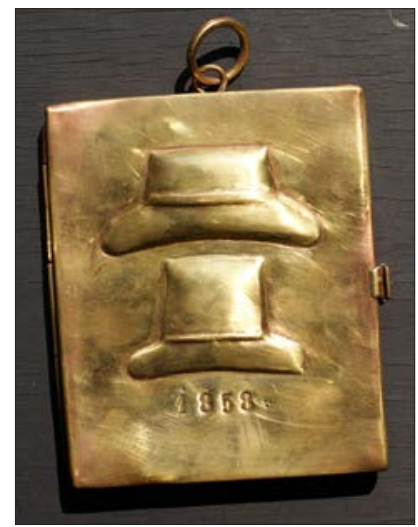

19. kép. Kalapos réz behívótábla 1858-ból 
A fazekasok „egy mázas kályhátzöld mázzal, szépet, jót, öreget, cifrásat, egy mázas kályhát, tarkát, fejér mázzal, jót, öreget, német módon csinált szép tarka, öszvejáró virágú, fejér mázast, jót, öreget, paraszt cifrás kályhát" csináltak.

Az asztalosok is az ácsokhoz hasonló béreket kaptak.

A borbélymesterek „emberfómosást” végeztek, de fó foglalkozásuk a sebek és betegségek gyógyítása volt. A 16-17. században a gyógyítás nem volt veszélytelen foglalkozás, mert „az sebesekre híven és szorgalmatoson viseljenek gondot, és ha gondviseletlenségek miá az sebes meghal, [...] fejekkel érjék meg."

A tölcséresmesterek (üvegkorongokból készítettek ablakokat) és a rézművesek következnek, majd a mészégetők, akik a meszet hordóval vagy kemence-, illetve veremmenynyiségben árulták.

„Az kereskedő áros emberek felöl nagy panaszolkodások hallatnak minden rendekröl, kik sem Istennel, sem lelkek ismeretével nem gondolván, marhájokat, ha lehetne, úgy adnák el, sok esküvések és csoda kigondolt excusatiojok mellett, hogy ha lehetne, tíz annyit adnak el, az mint vettek, nem gondolván keresztyén felebarátjoknak megcsalásával és értékének megfogyatkozásával."

A limitáció jobb híján használt kényszerítő eszköz volt. Mint ilyen nem érte el célját. 1626. június 12-én a gyulafehérvári országgyűlés egy újabb részletes törvényt fogadott el (EOE. VIII. 378-418.).

A korábbi limitációval szemben újdonság, hogy az „áros emberek”, kalmárok számára is előírják az árakat az olyan termékekre, amelyeket külföldről hoztak be. Ebbe a csoportba a külföldről behozott textilanyagok és füszerek tartoztak. Az említett textilanyagok: skárlát, igen jó, közönséges skarlatin és gránát, cimmazin, rasának singit $3 \mathrm{ft}$, jó fajlan- dis, lazur és angliai fajlandis, stemet, mayszler, karasia, fodor, kentula, morvai, braszlai, morvai posztó, veres és zöld skarlát.

A füszerek és más élelmiszerek, amit a kalmárok forgalmaztak: mandola, bécsi faolaj, törökországi faolaj, tengeri szőlő, malosa szőlő, kanári vagy velencei nádméz, confreit, bécsi sáfrán, bors, fahéj, török pogácsa, sáfrán, szerecsendió, fejércukor, veres cukor, festetlen és festett gyömbér volt.

Újabb kézművesszakmákat is bevontak a szabályozottak közé. Ilyenek voltak a gombkötők, fegyverderék-csinálók, fürészdeszkaés zsindelycsinálók. Ez utóbbiak esetében az oláhfalvi deszka és a zetelaki zsindely volt az alap, melyekhez viszonyították a többit.

1627 októberében újabb országos limitáció készült (EOE. VIII. 434-480.). A limitációk betartásának ellenőrzésére inspektorokat neveztek ki. Erdélyben Kapyi András, Balási Ferenc, Dávid Deák királybírót nevezték meg.

A limitációkból megismerhetjük a céhek termékeit, melyeket a piacra vittek. „Az árszintben, ízlésben eltérő kívánalmakat, változásokat jól tükrözik a céhbeli mestereknek kiadottárszabályok, limitációk, árlisták." (Imreh 1979. 176.)

A kolozsvári, 1622. május 1-23-i országygyúlés határozatainak 10. articulusa szerint „Nem kicsiny panaszkodásunk vagyon, kegyelmes urunk az míves emberek felöl is, holott noha arról egész országul limitációnk vagyon, mint és hogy kellessék marhájokat adni, az bor föképpen olcsó, mindazonáltal az ôk pothabealván és teljességgel elmenvén mellette, illetlen és felettébb való árat szabtak." Öszszehasonlítva az 1609. évi árakat az 1625. éviekkel 25-50\% drágulást figyelhetünk meg (Szádeczky 1913. 71.).

Az 1696. szeptember 19. és november 28. között ülésező országgyúlés határozatának 1. articulusában „Némely áros mívek limitációjáról" címmel újrarendezik az árakat. 
I. Rákóczi György uralkodásának éveiben (1630-1648) lazult az állami beavatkozás. Csak 1642-ben adtak ki újabb limitációt. Az 1609., 1627. és 1642. évi árakat összehasonlítva Szádeczky Lajos úgy találta, hogy az áremelkedés 20 és 100\% között változott, de olyan termék is volt, melynek ára meghaladta a 100\%-os emelkedést is. Ez a limitáció sokáig volt érvényben, és még 1687-ben is megerősítette az országgyűlés.

II. Rákóczi György uralkodásának kezdetén nagy változások történtek, visszaállították a szabad kereskedelem elvét, de fenntartották az állami monopóliumokat. Az 1653-ban jóváhagyott törvénycikk szövege: „Mindenféle míves emberek privilégiumok ezekkel a generális conditiokkal tartatnak meg és hagyatnak helyben: előben, hogy jó mívet míveljenek. Másodszor, hogy a városok és vidékek mindenek neme szerént való mívekből, vagy mívelt materiákból meg ne fogyatkoztassák és az eddig való abusus szerént külsó helyekre és néha országokra is hordván, a hazában ne szerezzenek szükséget." (Approbata Constitutiok. III. R Titulus IX.)

A 18. századból származik a szabócéh irattárában talált két szabólimitáció.

$\mathrm{Az}$ 1741-ben készült limitáció része a Mária Terézia rendeletei értelmében hét pontba fogalalt szabályzatnak, mely az inas, a legény és öreg mesterek soraiba lépését szabályozta. A limitált árak be nem tartásának büntetése három forint.

A székelyudvarhelyi szabócéh két fennmaradt árjegyzéke a 18. században használt ruhadarabokat és az árakat tükrözik:

„Nos Maria Theresia, Dei Gratia Romanorum Imperatrix etc. et Siculorum Comes. 64 Sub tutella ab anno '741 fecimus articulos.

1mo. A mely becsületes mester ember, vagy iffiu szabó legény bé jö, az várasunkbe, ha igaz che helyen tanult, tartozzék chehot követni, és ha olyan kuntárkodott vólna addig bé ne vétetődgyék, még az három forintat le nem tészi a chenak, a chebe állás lészen kész pénz 50: id est ötven magyar forint, négy font viasz, két veder bor, négy kenyér, három tészteséges fozik étel, kápaszta, résskársa és tejfeles lév, három sült, a melynek kettee malacz, a harmadik lud.

2do Az mester emberek gyermekei, ha chehot követnek tartozzanak, 20: forintal, 2: font viasszal, s egy veder borral, az étkekkel, a felyebb meg ért mod szerint, és ha valami szabó leginy mester ember gyermekit veszi is ugy.

3tio A mely ifiu mester megházasodik tartazik egy forintal, egy kenyérrel, egy fazék étellel, egy malacz sültel, panko[t] vagy halatis.

4to Az öreg mester asztalnak adása így van, készpénz három forint, két veder bor, négy kenyér, három fazék étel, három tészteséges sült, két malacz, s harmadik a lud, kürtös kalács, pánkó.

5to. Valaki szabó mesterségre idegen akarja adni fiat, két hétig lakik probahetet, ha tetszik a gazdának, és a gazda is tetszik az inasnak, maradása lehet, az után négy esztendeig szolgálya a gazdát, és óly kontráktust és kötést tégyen a nemes szabó chenak, hogy Udvarhely székben és városban, és a vár földin urak, papok joszágán nem kuntárkodik, ha nem örökös fia lészen a nemes szabó chenek, és két becsületes nemes emberek légyenek kezesek öss joszágos, a melyeken desummálhassan a nemes che 60: idest, hatvan magyar forintokat vinkulummul, tsak a le kötésének és kontrátusának erejével, toties quoties, a le kötésének és kontrátusának erejvel, toties quoties, a bé szegyőtetése kész pénz 12: idest tézes két magyar forint, négy font viasz, két veder bor, négy kenyér, három fozik étel, kápaszta szegyel, risskársa három kontzal, téjfeles lév, három tyúkkal, kettô sült, kettô malacz, a harmadik lud, mikar fel szabadul tartozik három 


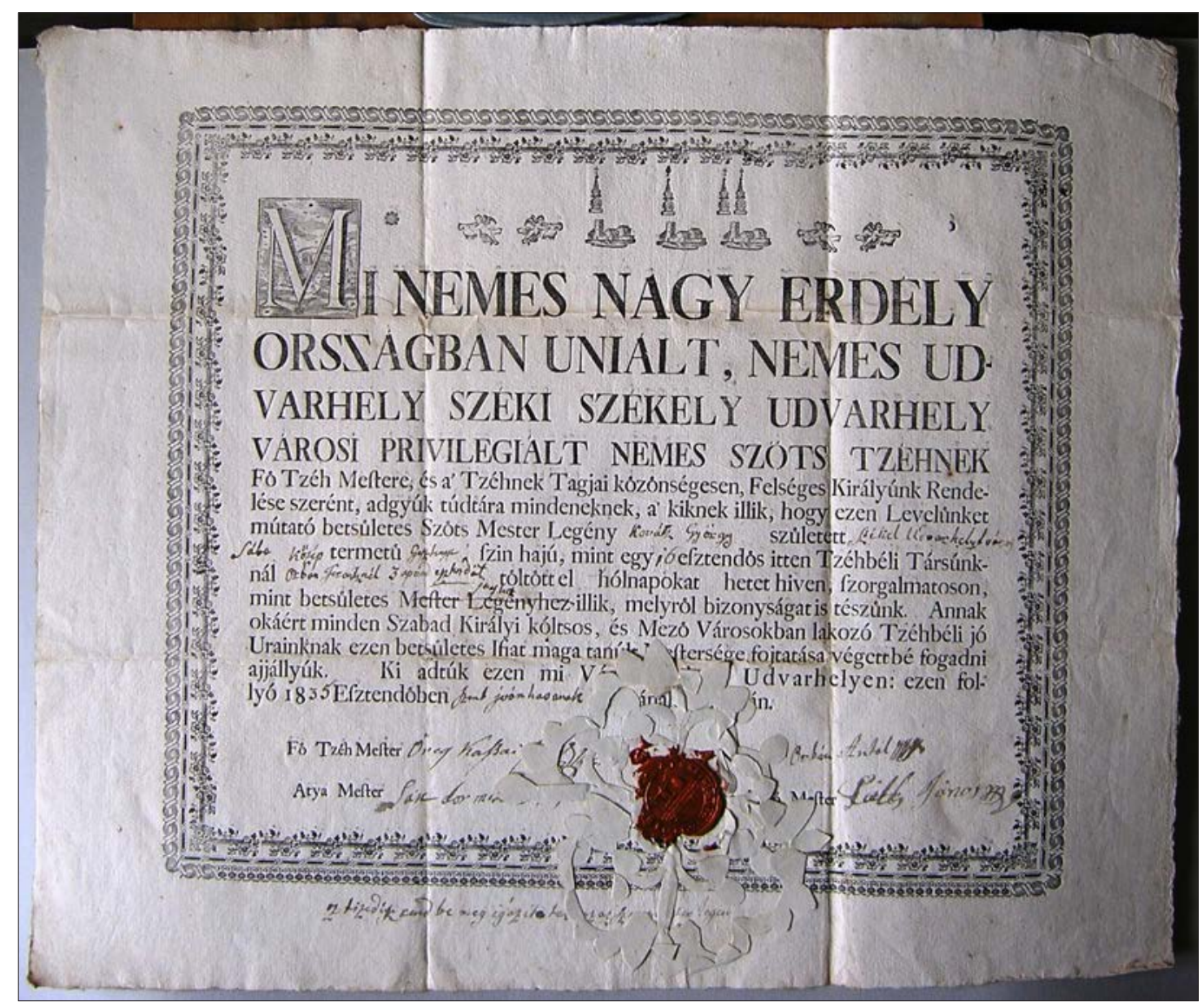

20. kép. A szűcscéh munkaigazolása Kováts György „szűcs mesterlegény” számára

forintal, pecsét pinzel, két veder borral, és az étkekkel, három tészteséges kalátsal, a mester ember gyermekit, ha sz atya fel nem mondja, vagy inasnak, vagy legyénnek nem tartozik egyebbel csak a pecsét pénzel.

6to Végeztetet a nemes chetól, hogy mikar mester legényt, az atya mestertöl el késérnek más ember méhelyiben, te hát az atya mester késérje méhelyben, és a fézetis szabja ki a gazda és mester legény elótt, és lássa jó szívvel, a chenak semmivel sem tartozik, sem a gazda, sem a mester legény. Mihelt a két hete kitelik, tehát a levelit adgya bé a che ládájába, ha be nem adgya [ha be utólagos betoldás] fizessen egy forintot a legény.
$7 m o$ Végeztetett a becsületes nemes chetól magak hasznokra, tapasztalván sok kárakat, a munkának rendes ára e szerint legyen. Ezek mint itt lévén, fel téve, valakik alább kezdik, másak kárával, az mint el rendeltük, 3 forint bírságon maradgyon, mind annyiszor valahányszot meg hallatik és igaz bizonyság által chehunkba bé jö, desummálhassounk, toties quoties.

\section{Egy togát}

24

Egy várasi firfinak vala mentét

12

Egy asszonynak valu (!) ángliai mentét 120

Egy frantzia pasztó mentét

120

Egy német kepenyeget 
Egy fél kepenyeget

6. Dolmány Lajbli készülettel

Egy aba kepenyeget

$-60$

7. Sújtásos Nadrág formával átal

Egy anglia dolomány

Egy közönséges háron petséti vagy

frántzia posztóból

Egy bérlet nadrág

Egy sinaras nadrág

Egy paszamantos anglia nadrág

Egy paraszt nadrag

Egy szoknyát primmel tsipkével

Egy paraszt szoknya

Egy sinaros és primes merevalut

Egy sinorral pasztu merevalut sinarral - 24

Egy paraszt merevalut

140

$-44$

$-30$

$-12$

$-24$

120

$-48$

$-36$

Egy rakot váll

$-15$

128

Egy parasz[t]

$-12$

Egy lájbit arany pálettal

360

Egy lájblit egy rend gombbal, két felöl jukkal

$-84$

Egy lájblit két rend bombbal s egy jukkal - 60

Egy világi papnak valu reverendát

Egy harisnyát posztoson

274

Egy paraszt harisnyát

274

$-12$

Az egész che meg egyezett azan kezbe adassal, hogy fel fogatták mind négyen az ifiak ugy mint Szentes Abel, [...] Szakhirda Janos, Szabo Janos es Sojmosi Szabo Janos, hogy őkegelmeket ha rajta talaltatik valaki közöttük (vagy közöttük), hogy alab dolgoznak amint egyenes mután(?) hárman toties quoties.

174-ik határoztatot czéhbeli árticullusok. A szabó céh papirfelzetes pecsétjével.

\section{Specificatio a munkák áráról}

1. Mentének Tsinálása keresztes Bot hajtással

2. Mente Tsinálás Simán, Ismét Ugy

3. Mente keszülettel Tsinálva

4. Dolmány Tsinálás ugyan eszerint

5. Dolmán Laibi Tsinálás súlytással vizfolyt

Rft $\quad x$

$2-$

140

125

$-\quad-$

18
170

kötve

8. keresztúl kötetlen formával

9. Nadrág k... 3 renddel

10. víz folyással karikoval 3 rendel 1 - 57

11. Nadrág egy rend Sinorral

- 30

12. kissebnek

$-24$

13. Béletlen Nadrág Sujtassal

$-30$

14. Béletlen Nadrág egy rend sinorral - 18

15. Béletlen Nadrág Úgy kitsinek $\quad-12$

16. Rövid Laibi Átal Gombolva

$-36$

17. Rövid Laibli egy rend jukal

18. Rovid Lájbi kari kar ikoval

$-30$

19. kerek köpenyeg Tsinálása

20. Ujas köpenyegnek Tsinálása egész Barab

21. Kaput Tsinálás

22. Frák két rend Gombbal a válláig

23. Ujas Lajbi Tsinálás ordinár

24. ... Tsinálás

$-31$

$2-$

25. Ordinar vigano

26. Selyem vigano

27. Muszlinbol

28. Sláfrok ordinare

29. Slafrok

30. Szoknya Tsinálás Selyemből

31. Szoknya ordinar

32. Kom... Tsinálás

33. Stu ... Rekli

34. Ordinar Laibli

35. Selyem Lajbli Tsinálása vak (?) modra

36. Rojt ... ... Tsinálása Posztoból

37. Rojt ... Ordinar

38. Selyem Melyrevalonak Tsinálása 39. Hal ... kirakva Tsoposzon... 2 40. Melyrevalo ordinar $\quad-30$

41. Fejer nép kerek Lajbli Tsinálás - 30

42. Fejér nép Hosszu Bunda Tsinálás 112 43. Ferfi Hoszu Bunda Tsinálás 18 


\section{A pénzforgalom}

A vásárokon megjelenő termékek árának limitálása mellett a „mesteremberek és egyéb kereskedô rendek" (1624) által forgatott pénz és a pénzverés is eszköz volt a fejedelmek, az államhatalom terveinek megvalósításában. A fejedelmek hamar felismerték, hogy a gyenge minőségű ezüstből vert külföldi (fóleg lengyel) pénzérmék behozatala és a jó erdélyi aranyak kivitele szegényíti a kincstárt, „aranyat, tallért és jó dutkát kivinni nem szabad, fó- és vagyonvesztés terhe alatt" (1622). 1625-ben a császárral is tárgyalt a rossz pénz forgalmon kívül helyezéséről (EOE. VIII. 246-247.). Látván „A marháknak és egyéb mindenféle emberi szükségre való dolgoknak és áruknak képtelen és hallatlan drágaságát", szabad legyen mindenféle marhával szabadon kereskedni, a lovakkal és ökörbőrrel való kereskedés a fiskusnak legyen fenntartva (EOE. VIII. 267-268). Bethlen Gábor felülvizsgálta a korábban fejedelmi tulajdont képező földeket 1615 után, ezzel is növelte tervei megvalósításának gazdasági hátterét.

A pénzforgalom szabályozására a fejedelem, súlyos büntetéssel fenyegetve az ellenszegülőket, parancsba adta az új pénz elfogadását a kereskedelemben: „Egynehany felöl való relatiokkal értjük, hogy ismét rút veszekedés kezdett gyakori helyeken az reformált ötlotos 10 pénzünknek ususában, [...] valaki az ellen cselekszik és ez mostani pénzt el nem venné, mindennemú javait confiscaltatjuk és azon pénzt homlokába sütvén fejét is elveszíti." 13

A brassói garas nem volt gyengébb más pénznél, de mivel előszeretettel hamisították, 1615-ben beszüntették verését. A hamis és áldutkák miatt a dutkát, ha mégolyan jó is, el nem fogadják, úgy határoztak, hogyha anyaga nem vas, réz vagy ón, mindenki fizethet vele.

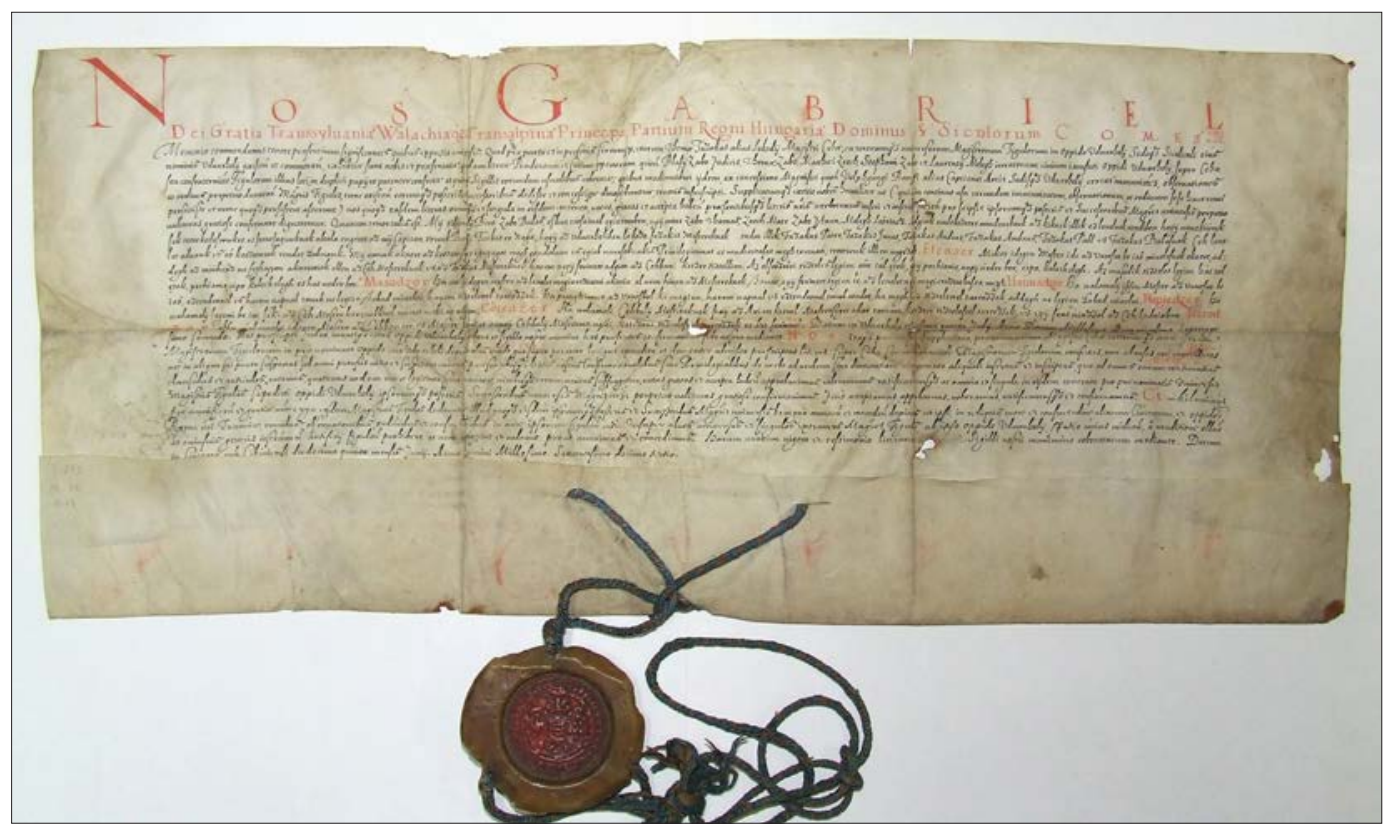

21. kép. A székelyudvarhelyi fazakascéh kiváltságlevele. Kibocsátotta Báthory Gábor fejedelem Nagyszebenben, 1613. június 15-én. F 249, 617 sz.. (Fotó Bicsok Zoltán) 
A rossz pénz ügyében a fejedelem rendeletet adott ki 1625-ben. Az újabban vert 3 és 5 garasos és az aprópénzt nagybányai és kassai pénzverdékben verték. Az új veretek megjelenésével egy időben a forgalomban lévő garasokat kivonta a forgalomból. Vagyonvesztés terhe alatt megtiltotta a Lengyelországban vert polturák elfogadását: „ne éljen, ne adjon semmit és el ne vegye, hanem az mostan kibocsátandó jó pénzünkkel, arannyal, tallérral éljen minden, egy aranyat két forintban, egy tallért százhuszonöt pénzben számlálván". A reformot kiterjesztették Ausztriára és Lengyelországra. A lengyelek megígérték, hogy a polturát a liga (Ausztria és Erdély egyezménye a pénzkibocsátás tárgyában) mintájára fogják verni és mindhárom „birodalomban” forgalomba lesz az új pénz, vagyis „az háromféle egy ligára vert pénz egyaránt járjon" (EOE. VIII. 309-310.). Bethlen Gábor is kénytelen volt követni kortársai példáját és kétes eredményű pénzrontást is gyakorolni. Az 1617-1620 között vert pénzek még 0,420 finomságúak, az 1620-1622 közöttiek 0,375, az 1623-1624 közöttiek már csak 0,315 finomságúak.

A rendelet szabad utazást biztosított a kereskedőknek: „Minden kereskedő rendek azért szabadoson menjenek, jőjenek, életeket, nyereségüket keressék, az marhát isten igazsága szerint való árán adják. Azonképpen mészárosok, tősérek, és az egész község szabadoson adjon-vegyen, kereskedjék, városokra mindent bevihet, jó pénzt adnak érette, ki ez után mind az három birodalomban egyaránt eljár, hogy immár az nagy drágaság és sok panaszkodás forduljon jó állapotra." (EOE. VIII. 310.) A régi garast kivinni az országból nem szabad, hanem akinek ilyen garasa van, vigye a kassai és nagybányai „minczházainkba”, ahol beváltják új garasokra.

A korszak legértékesebb pénzneme a ma- gyar aranyforint vagy dukát volt. „A pénzegység a magyar mintára vert dukát volt, melynek többszörösei közül gyakori a kettôs és tízes arany, elöfordul azonban, bár némelyik csak kivételképpen, a 2, 4, 5, 6, 7 aranyos pénzdarab is." (Honvári 2002.149-150.)

Az ezüsttallért külföldről hozták be, de Szebenben már 1552-ben verték I. Ferdinánd utasítására, és gyorsan a legkedveltebb pénz lett Erdélyben. Jellemző, hogy a pénznek a dénárt nevezték, amely a legnagyobb menynyiségben volt forgalomban. Az osztrák és német krajcárok és a lengyel garasok is nagy mennyiségben kerültek Erdélybe. Forgalomban lévő külföldi tallér volt az imperialis, a gréci és az oroszlános, a szeges, a Ferdinánd.

Az átváltási arány 1 krajcár egy dénár volt. Erdélyben 400-500 dénár volt egy aranyforint. Átváltási pénznem (számítási pénz) volt a magyar forint, amely 100 dénárral volt egyenlő. Számítási pénz volt a rénes vagy rajnai forint, ennek értéke 60 krajcár vagy 120 dénár volt. Újabb rendeletet ad ki a fejedelem 1626. február 24-én az új pénz kötelező elfogadása érdekében (EOE. VIII. 310-311.). Parancsba adta, hogy az új pénzt mindenhol

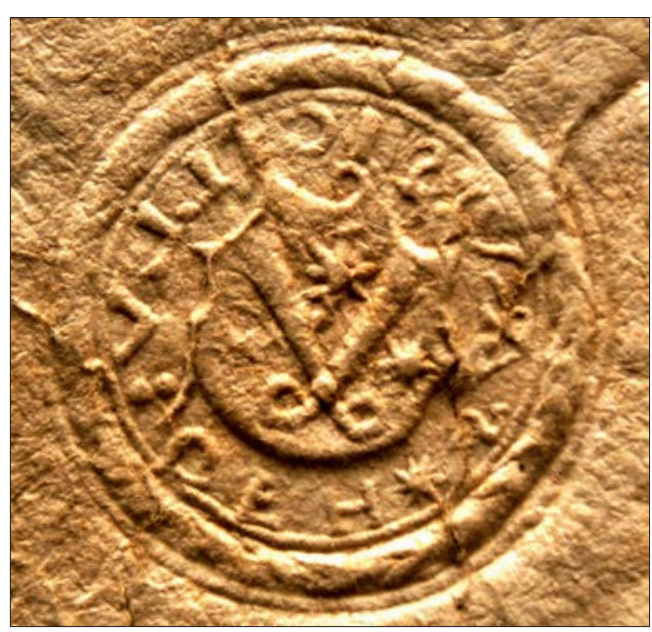

22. kép. A szabócéh régebbi pecsétjének papírfelzetes lenyomata 
fogadják el. „Látván az országban az ó- és új monetában való nagy válogatást, kiváltképpen az együgyú közrend között annyira, hogy ki az ó pénzt, ki az ő felsége mostani öt lótos pénzét nem akarván elvenni", az árfolyamát a régihez igazítják. Minden régi pénz „abrogáltatott". A rendeletet Debreczeni Tamás kincstárnok írta alá.

1664-ben a januári 31. - február 24. között tartott országgyúlés a XXXVI. tc. elfogadásával újra intézkedett a jó pénz külföldre vitelének megtiltásáról. Mivel káros az országra, a jó pénz „kihordását” mindenki számára megtiltják. A harmincadosok és vámosok szigorúan vegyék el pénzét, ha valaki ilyennel próbálkozna, és halálbüntetést helyez kilátásba a tisztviselők számára, ha tudtukkal történik. A tallérok és arany váltásáról úgy intézkedett az 1666. évi februári országgyülés, hogy „egy tallért két forinton, egy aranyért négy forintot adnak" hivatalosan (Huszár 1995).

A napoleoni háborúk konjunktúráját igyekezett ellensúlyozni 1811. március 15-én elrendelt devalváció, ez 1816-ban ért véget, mikor a pénzrendszer visszatért a konvenciós alapra. A birodalomban 360 millió birodalmi tallér, Erdélyben Kővári László számításai szerint 10 millió tallér lehetett. Az évente bányászott aranyból Gyulafehérváron 120000 érmét vertek, ami forgalomba is került Erdélyben.

\section{Pénzrendszer a birodalomban}

Aranypénzek:

- souverains d' or $=13 \mathrm{ft} 20 \mathrm{x}$

- császári vagy körmöci arany $=4 \mathrm{ft} 30 \mathrm{x}$, ami 4 rf 30-40 x között ingadozik

Ezüstpénzek:

- koronástallér $=2 \mathrm{ft} 12 \mathrm{x}$

- félkoronás tallér $=1 \mathrm{ft}$

- negyedkoronás tallér $=33$

- közönséges tallér $=2 \mathrm{ft}$ félnek $=1 \mathrm{ft}$

- negyednek $=30 \mathrm{x}$

- apróbb ezüst $=20,10,5 \mathrm{~g}$

$-\operatorname{aras}=3 \mathrm{p} \mathrm{x}$.

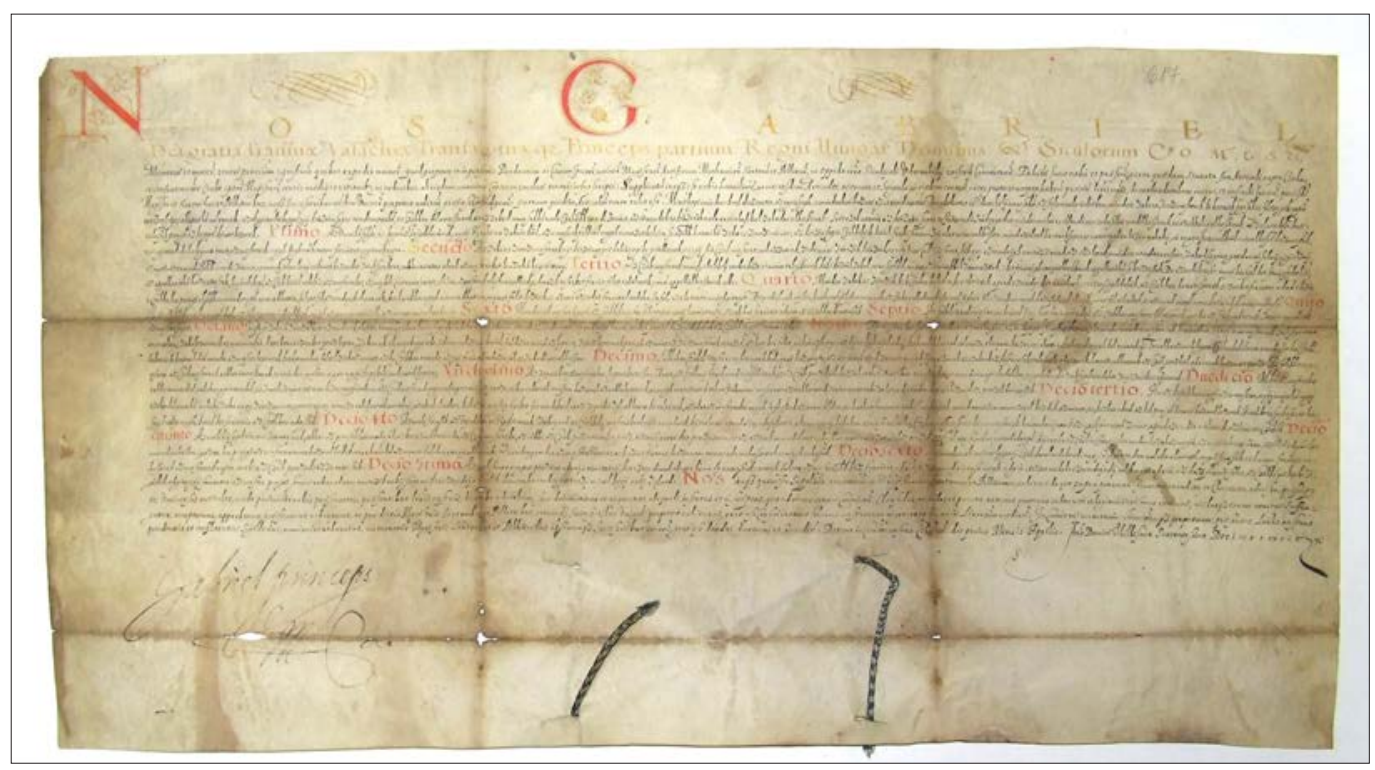

23. kép. A székelyudvarhelyi szabócéh kiváltságlevele. Kibocsátotta Báthori Gábor fejedelem Nagyszebenben 1613. április 1-jén. F. 249, 36. sz. (Fotó Bicsok Zoltán) 
Rézpénz:

- 1 krajcár 1/2 és 1/4 pengő krajcár értékü, 30, 15, 6 krajcár értékben

Virtuális (számítási) pénz:

- rénes vagy német forint $=60 \mathrm{x}$

- vonás forint = 3 Máriás vagy 51 krajcár

- magyar forint = 100 démár vagy 50 krajcár

- kopac forint = 48 kr váltóban

- susták = 6 váltókrajcár

- poltura = 11 váltókrajcár.
Az erdélyi hivatalokban mindig pengőben, a magyaroknál mindig németben, a székelyeknél pedig mindig magyarban kell érteni (Kőváry 1847). Papírospénzek is forgalomban voltak, az ún. váltócédulák 1, 2, 5, 10, 20 , 100 váltó forint értékben.

\section{A mértékekről}

Mindennapi életünk szinte észrevétlen, ugyanakkor fontos velejárója a mértékek használata. Szigethy Gyula Mihály profesz-

4. táblázat. A méterrendszer bevezetése előtt használt erdélyi mértékek

\begin{tabular}{|c|c|c|c|}
\hline Mérték & Használat ideje & Más mértékhez hasonlítva & Nagysága metrikusan \\
\hline \multicolumn{4}{|c|}{ Űrmértékek } \\
\hline hordó, kis & \multirow[t]{3}{*}{1556 után } & 20 erdélyi vödör & 2181 \\
\hline hordó, földes & & 40 erdélyi vödör & 4361 \\
\hline hordó, öreg & & 80 erdélyi vödör & 8721 \\
\hline hordó, kis & \multirow[t]{3}{*}{1823 után } & 5 erdélyi vödör & $56,60 \mathrm{l}$ \\
\hline hordó, közép & & 10 erdélyi vödör & $113,20 \mathrm{l}$ \\
\hline hordó, nagy & & 40 erdélyi vödör & $452,80 \mathrm{l}$ \\
\hline icce & 18. sz. & $1 / 2$ erdélyi kupa & 0,68161 \\
\hline icce & 1823 után & $1 / 2$ erdélyi új kupa & $0,7074 \mathrm{l}$ \\
\hline köböl & 1823 után & 8 új erdélyi vödör & 90,541 \\
\hline kupa & 17. sz. & 1 kolozsvári kupa & 1,36231 \\
\hline \multicolumn{4}{|c|}{ Száraz űrmértékek } \\
\hline mérő & 1823 után & 42 új erdélyi kupa & 44,57 \\
\hline véka & 1647 után & 16 erdélyi kupa & 16,39 kg búza \\
\hline \multicolumn{4}{|c|}{ Súlymértékek } \\
\hline \multirow[t]{3}{*}{ font } & 1680 után & 20 ezred lat & $0,3895 \mathrm{~kg}$ \\
\hline & 1690 után & 32 ezred lat & $0,4489 \mathrm{~kg}$ \\
\hline & 1721 után & egy bécsi font & $0,5600 \mathrm{~kg}$ \\
\hline \multirow[t]{3}{*}{ mázsa } & 1680 után & 144 erdélyi font & $56,09 \mathrm{~kg}$ \\
\hline & 1690 után & & $64,64 \mathrm{~kg}$ \\
\hline & 1721 után & egy bécsi mázsa & $56,00 \mathrm{~kg}$ \\
\hline \multicolumn{4}{|c|}{ Darabmérték - sómérték } \\
\hline sómérték & 12. sz. & & \\
\hline 2 hajósó & 1575 & vízaknai só & \\
\hline 3 kősó & 1423 & & $5,50 \mathrm{~kg}$ \\
\hline
\end{tabular}


szor 1834-ben így írt a mértékekről: „Tárgya a' mérés Tudományának minden kiterjedés, mely hol a' lineákban, széjjel, hoszszban, méjben, hol a' lapokban, hol a' testek üregében, méröjében fordul elő. Az honnan a' mérés Tudománya három részekből áll. [...] Vagyon haszna a' Mérés tudományának a' közönséges életnek minden nemében: a' bányász mesterségben, a' földmüvelésben, az építésben, $a^{\prime}$ kézi-mesterségekben, $a^{\prime}$ testek' természetéről szóló tudományban, a' festésben, rajzolásban, és a' metszésben." (Szigethy 1834. 543-568.)

„A kolozsvári köbölrendszer a középkorban is nagy elterjedettségnek örvendhetett, mert mindjárt a Fejedelemség kialakulásakor uralomra jutott. Harcot egyedül csak a szászok mértékrendszerével kellett vívnia, de ebböl is hamarosan győztesen került ki. 1549-ben az országgyúlés Erdély-szerte a kolozsvári köbölt tette kötelező gabonamértékké, a borvásárra ugyanakkor a szász mértékrendszert hagyta meg." (Jakó 2016. 471.)

Az 1578. évi áprilisi országgyűlés főleg a vásárokban is használt mértékeket „magyarországi atyánkfiaival egyetemben, mivel egy hazába vagyunk, az sok különb-külömb féle helyeken való mértékek, úgy mint köböl, ejtel és mázsa letétessenek, hanem az egész szászság, mindenütt ez országban egy köböllel éljen, mind várasokon, mind falukon, szebeni köböllel, egyéb minden, kolcsos, szabad és mezővárosok, falus helyek az kolosvári köböllel éljenek, ahhoz szabva köblöket. A székelység azonképpen minden helyeken kolosvári köböllel íljenek és másával. (EOE. III. 17.) Az ejtel mérete a kolozsvári legyen [...]. Singgel, fonttal (Finály 1866.) és egyéb efféle mértékkel egyaránt éljenek minden széken minden rend. [...] Köböl pedig az kolosvári legyen [...]"

Az 1578. decemberi országgyülés határozata szerint állami feladat volt a mértékek ellenőrzése és az azokkal való visszaélések megtorlása. Az 1622. májusi országgyűlés határozatainak 11. articulusa szerint minden városbeliek „vékájok, eyteleket és vedreket megváltoztatták, hol megnagyobbították, hol megkisebbítették, magok hasznát követvén bennük, nekünk nagy kárunkra és fogyatkozásunkra". Leszögezte, hogy minden város vékáját, ejtelét, vedrét Szent Margit napjára produkálja Fejérvárott pecsét alatt, s azt megváltoztatni nem szabad. A pontos mértékek használata közérdek volt (EOE. VIII. 99.). Az Approbata Constitutiók előírták, hogy a „vármegyékben is ejtelekkel, vékákkal, köblökkel, singekkel, mázsákkal és minden egyéb mértékkel egyenlőképpen éljenek, és mindezek a kolozsvári mértékhez alkalmaztassanak, úgy hogy egybealkalmaztatván a mértékeket a kolozsvárival, az egész szászságra Szebenből adattassanak ki a többi városokra, és azokról a falukra. A székelységen Udvarhelyrôl adattassanak ki a több székekre és városokra és azokról falukra."(Approbata Constitutiok. III R. Titulus XLV. art. 1.). Székelyudvarhely város elöljáróinak 1588. évi perében egyik tanú ezt vallotta: „Tudom azt is, hogy ki menének az Gyepü ciherjébe, mivel hogy sok panasz vala, hogy egy néhányan bírnak az Gyepü ciherjébe, kiment az város, kötelet (!) vittek, hogy meg mérjék, ott azért mindennek részében hagyták, a' kinek ott földje vala, másutt is sok költséggel a' helyett mértek földet."14

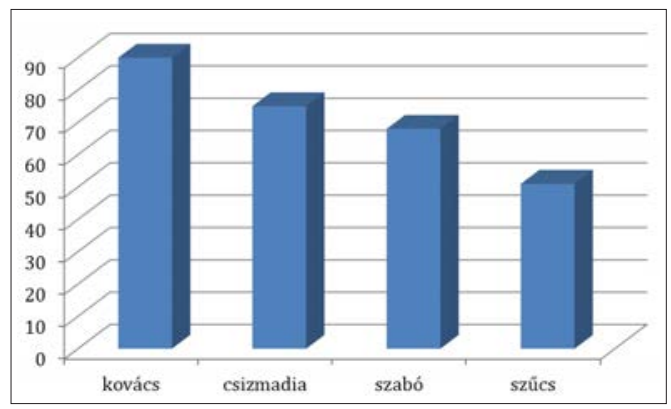

5. ábra. $A$ vidéki kézmüvesek négy legnépesebb csoportja 1820-ban 
Egy udvarhelyszéki 1589. évi perben említik, hogy a románok „oszt úgy adtak neki két disznót, egy tömlöt, s három köböl búzát, vagy kettőt" (SzO. 1983. 59.). Egy 1590-ben folytatott perből megtudjuk, hogy „minden húsz juh után két sós sajtot, két tömlőt és egy vider ordát ad" (SzO. 1983. 104.). Szent Márton-nap utáni pénteken. 1589-ben Farcádi Péter „nyolc forintos (egy ökör ára hat forint volt) és nyolc és fél köböl búza adóságát" említették (SzO. 1983. 89.). A máréfalvi pereskedők 1589-ben „tíz sing héján száz sing vásznat" említettek. Egy ittasan elkövetett gyilkossági perrel kapcsolatos vallomás jegyzőkönyvében olvashatni: „no gazda, hány kupa bort hozattál minekünk? Én mondám, hogy egy vider bort hordottam." (SzO. 1983. 126.) A sört viszont hordóval mérték: „az egy hordó sert, a pálfalviak lófejek hozták" (SzO. 1983. 23.).

Az 1625. évi májusi országgyúlés limitációja kötelezte a kádárokat, hogy „igaz mértékre csinálják az ő míveket és reá vigyázzanak a ché mesterek minden városokon, falukon penig az bírák hütök szerint. Az öreg hordó nyolcvan vedres legyen igazán. Az földes negyvenvödrös legyen. Az egész hordót, ki nyolcvan vödrös, jó, jól csinált, jól kötött, adják 1 forinton 50 pénzen." (EOE. VIII. 293.)

A számtalan mértékek között sajátságos a zetelaki zsindelymérték, amelyben az $1,9 \times 11,0 \times 71,1 \mathrm{~cm}$ nagyságú zsindely, és a deszkamérték, ami egyenlő volt 0,05 cm-rel.

A mértékek használatát a 16. századtól törvényekkel, rendeletekkel szabályozták, hogy kizárják a hamis mérőeszközöket, és lehetetlenné tegyék a hamis mértékek használatát és a hamis méréseket. Törekedtek az egységesítésére is, ez a bécsi rendszer bevezetésével nagyrészt megvalósult, de a dolog csak a méterrendszer bevezetésével oldódott meg minden részletében.

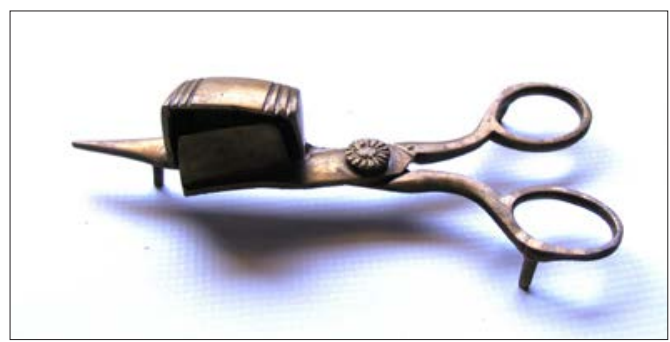

25. kép. Szabóolló

A búza és gabona ára rendkívül növekedett: „félvén attól, hogy az szegénység éhhalásra ne jusson, és egyszersmind akarván az sok rendkívül búzával, gabonával kereskedőket megzabolázni, szükségesnek ítéltük, hogy ámbár ily nagy szükségben legyünk is, hogy a búzának és egyéb gabonának árát meglimitáljuk. Idegen sem a piacon, sem háznál nem vásárolhat. A legszebb búzának vékáját egy forintnál, a zabnak 25 pénzért, az alakornak és árpának vékáját 33 pénznél, a kölesnek 10 pénznél, a haricskának 50 pénznél feljebb adni senki ne merészelje."

A régi mértékrendszerek (számunkra ma már érthetetlen) bonyolultsága megmaradt a méterrendszer bevezetéséig, annak ellenére, hogy Bécsből a mértékek egyszerűsítését akarták elérni. Ez azonban megtört a parasztság gyanakvásán és megrögzött félelmén minden reformkísérlet esetében. ${ }^{15}$

A 4. táblázat csak egy nagyon kis részét mutatja a méterrendszer bevezetése előtt használt mértékeknek. Pontosabban, csak az erdélyi mértékekből tallóztunk.

A zsindelyt (asser tegularis, scandula latinul és Schindel németül) a tetőfedésre használt fenyőfalapok jelentésben az írott forrásokban 1405-től ismerjük. A tetőszerkezet léceire keményfa szegekkel erősítették fel, de már korán megjelentek az erre a célra kovácsolt vasszegek. Az 1627-évi erdélyi limitációban így írnak: „A zetelaki [Udvarhely] és azon vidéken lévő falukban csinált sendely, 


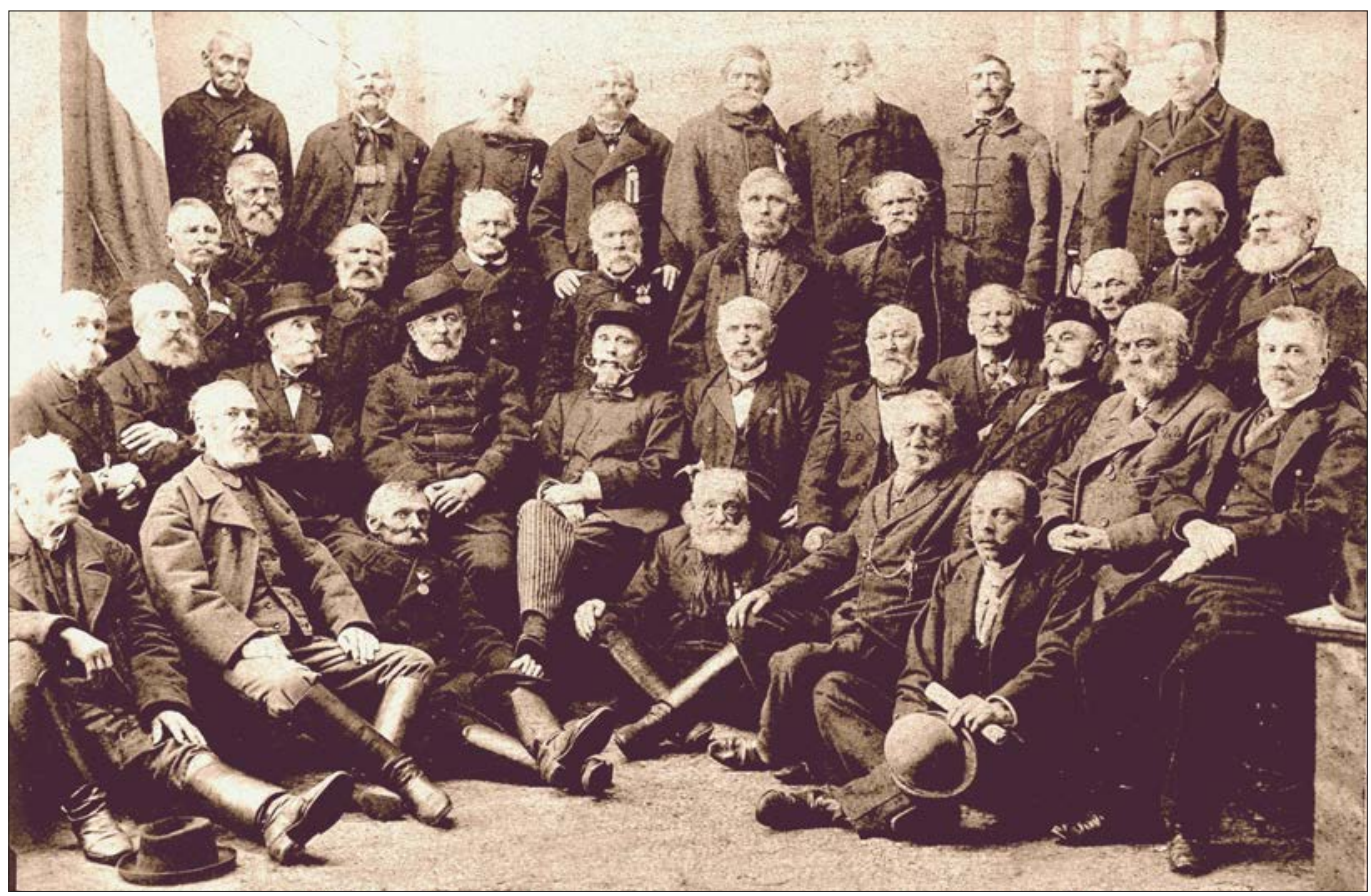

26. kép. A székelyudvarhelyi Szabó Ipartársulat tagjai 1924-ben egy szabásztanfolyam elvégzése után

melynek hoszsza háromarasznyi, szélessége egy hüvelykes tenyér". ${ }^{16}$ Egy másik udvarhelyszéki jellegzetes mérték az oláfalvi deszka volt. A mértékek sokaságának az 1876. évi II. törvénycikk vetett véget, amelyet az akkori szóhasználattal élve „civilizált országok” valamennyien elfogadtak. Ezzel a nemzetközi kereskedelem útjából nagy akadály hárult el. Bécs sikertelen ostroma után (1683) a Török Birodalom magyarországi uralma látványos gyorsasággal összeomlott. A 17. század végén az Erdélyi Fejedelemség a Habsburg Birodalom egyik tartománya lett. A céhek más gazdasági viszonyok közé kerültek. A központi hatalom barátságtalan politikát folytatott az elavultnak ítélt, a gazdasági fejlődést akadályozó céhekkel szemben. Arra törekedett, hogy uniformizálja, központi felügyelet alá vonja a sokszínű céhvilágot.

\section{A céhen kívül dolgozó iparosok, a kontárok}

A városi kézművesek termelését (ezek rendszerint céhtagok voltak) a vidéken, falusi környezetben dolgozók egészítették ki. Számuk nagyobb volt, mint amire az összeírásokból következtethetünk. A közhelyeken túl nem járhatott messze a valóságtól a Kézdivásárhelyen 1820-ban készült összeírás adatközlője, mikor azt állította: „Mi magunk [a jobbágyok] is többnyire mind mesteremberek vagyunk. Ki suszter, ki szabó, ki kalapos, ki üstgyártó, ki asztalos, ki szígyártó. És minden kézimunkánkot készpénzen itten eladhassuk. Emellett vagynak ezen helységben céhok, úgymint: csizmadia-, tímár-, szőcs-, szígyártó-, fazakas- és mészároscéh, melyekben vagynak kiben-kiben 20, kiben 50, kiben 60-70, s még 100 mesteremberek is. Úgyhogy összesen ezen 


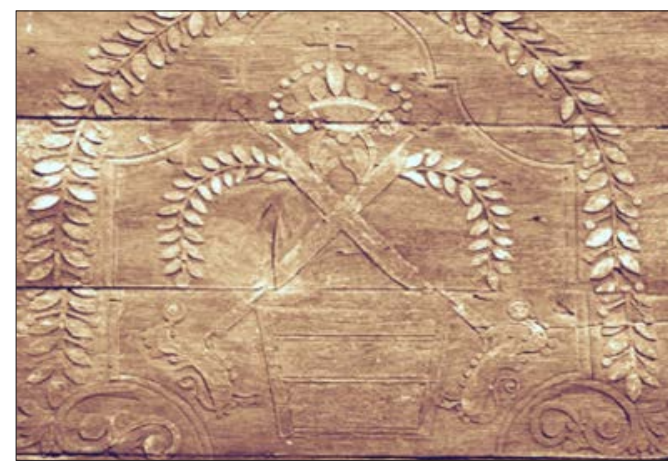

27. kép. Egy városi székelykapu tükrében tímárcímer. A kaput állítatta Tamás Lajos és felesége Laiber Anna 1853. október 27-én. Faragta Kovács Péter. (Jelenleg a szejkefürdői kapuk között a nyolcadik.)

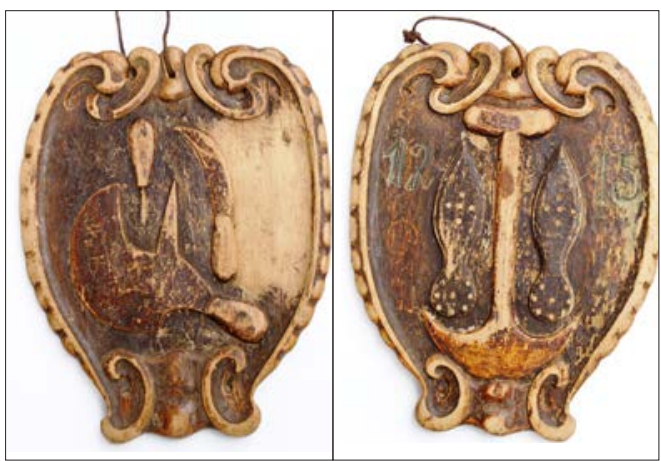

28. kép. A székelyudvarhelyi vargacéh behívótóblájának elö- és hátlapja

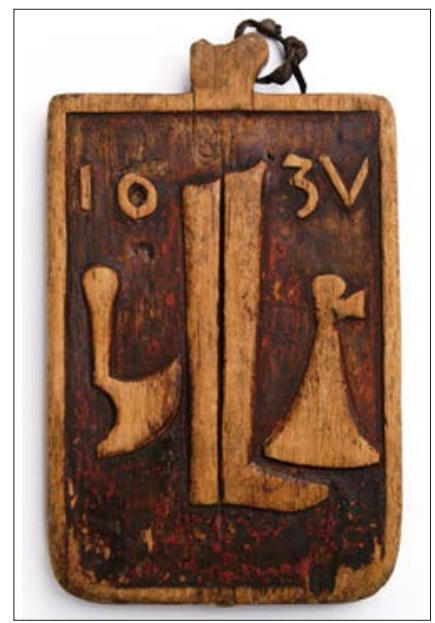

29. kép. A csizmadiacéh behívótáblája 1635-ből helységbe[n] tanáltatnak 300 mesteremberek." (Takács 2002. 201.)

Az udvarhelyi céhekben dolgozó mesterek mellett a szék falvaiban még sok kézműves dolgozott. Ezek a helyi, a lakóhelyük közelében gazdálkodók igényeit elégítették ki. De ennél nagyobb körzetnek is dolgozhattak, sőt a vásárokban is megjelenhettek. Legtöbb volt közöttük a kovács (90), mert állandóan és helyben kellett elvégezni a patkolást (patkoló kovácsok), munkaidőben a szerszámok élesítését, a kisebb-nagyobb javításokat. Mellettük elenyésző számban dolgoztak lakatosok is. A szabók specializált csoportja volt a harisnyaszabóké (székelyharisnya), akik a zeke és más szabókkal együttesen 68an voltak. A székben 1820-ban (lakossága 96929 fó volt 1868-ban Orbán Balázs adatai szerint) 463 falun lakó kézművest számoltak össze a függőségben élők adózását előkészítő felméréskor. A valóságban ennél nagyobb lehetett a kézművesmesterek száma, mert nagyon sokan foglalkoztak fatányér-esztergályozással, borda-, szúszék- és teknőfaragással, szekérkészítéssel, bőrcserzéssel, hordókészítéssel és sok-sok más munkával, eladásra is termelve.

Udvarhelyszéken 1781-ben összeírták a cigányokat. A nem teljes összeírás szerint is öt járásban, a bögözi, homoródszentmártoni, farcádi, etédi és bözödi járásokban összesen 600 cigánycsalád élt, 3500 felnőtt, 779 fiú- és 674 leánygyermekkel. A többi járásban lakókat is beleszámítva 4000 körül volt a számuk, ami a jobbágyok fele volt. Az erdővidéki Bardóc fiúszéken 59 családot írtak össze 112 gyermekkel. ${ }^{17}$ Ez azt jelentette, hogy 200 körül volt a számuk. Foglalkozásukat tekintve legtöbb volt köztük a kovács. Ezeken túl dolgozott még csizmadia és halász. Ugyanakkor a szék kilenc járásában 1788-ban volt 339 főúri és nemes család, 1786-ban 912 volt 
a számuk, amelyben nem volt beszámítva a közszékelyek száma, csak a birtokos és armalista családokat sorolták a rendbe. A székben volt 119 falu, 10736 házszám, 11119 család, hivatalnok 11, mesterember 185, földmíves 5660, előkelő polgárok és földművesek utódai 4906, belső telkes 4989, katona 69, egyéb foglalkozású 2322, fiúgyermek 12 évig 5553, 13-17 éves fiú volt 2032, nő volt összesen 25639 . Így a lakosság száma összesen 52529 fó volt, 1787-ben ez a szám 51 354-re apadt (Jakab-Szádeczky 1901. 529-530.).

A pénzforgalom viszonylag alacsony szinten mozgott, a parasztgazdaságok minden lehetséges területen önellátásra rendezkedtek be. „A fejérnépek a magok szötteményekkel ruházkodnak" - jegyezték meg Bencéd 1820. évi összeírásában, és még sok hasonló állítást találunk. A ruházat majdnem minden darabját előállították, megszőtték az asszonyok vagy a falusi mesterek. A bonyolultabb ruhadarabok, mint a harisnya vagy a felsőruházat esetében a helyi szabókat hívták segítségül, akik egy zsinegre bogokat vetve jegyezték fel a mértéket. A reformkori feudális társadalom autarchiája tovább élt a Székelyföld falvaiban. Pénzre csak néhány meghatározott helyzetben volt szüksége a földesuraktól függő viszonyban élő jobbágynak vagy akár szabad közszékelynek. Pénzt csak adófizetésre, olyan dolgok megvásárlására használt, amit nem tudtak előállítani, vagy a faluban nem volt fellelhető. „Évente egy-két piacra hajtott barom fedezte az egyes családok számára a nélkülözhetetlen pénzalapot vagy csereterményt." (Gazda 1998.) A 19. században itt is színesebbé vált a ruházat, elsősorban a nőké. „A kiváltságosság tudata hivalkodó fogyasztást vont maga után, státusszimbólumok igénylését. Ilyen meggondolásból építettek maguknak a székelyek mázas kandalóval ellátott, viszonylag módos, tágas házat, állítottak portájuk elé díszes, rangra utaló székelykaput, és ilyen meggondolásból igyekeztek kialakítani, - a divatot bizonyos késéssel követô, - látványos viseletüket. Ugyanakkor a szegénység korlátokat is szabott törekvéseiknek, ezért e javak egy részét házilag voltak kénytelenek előállítani." (Gazda 1998.)

A vidéki mesterek sem voltak minden esetben kontárok (ahogy általában értelmezzük), csak abban az értelemben, hogy nem voltak tagjai valamelyik céhnek. Ennek nagyon sok oka lehetett. A céhkiváltságok hatálya rendszerint csak a városra és annak környékére, négy mérföld ${ }^{18}$ távolságra terjedt ki. Ezen túl a falvakon a földesurak és a lakósok számára dolgozhattak. Ha egy városi céh nem tudta elegendő jó minőségű termékkel ellátni piacát, a város elöljárói beengedhettek vásáraikra máshonnan érkező termelőket is. Más dimenzióban hasonló folyamat ment végbe a kisvárosokban is. Szerződésben kötötték ki, hogy az inas és a legény ruhát is kapott mesterétől. A legények vándorlása eddig fel nem mért változásokat, szokásokat honosított meg.

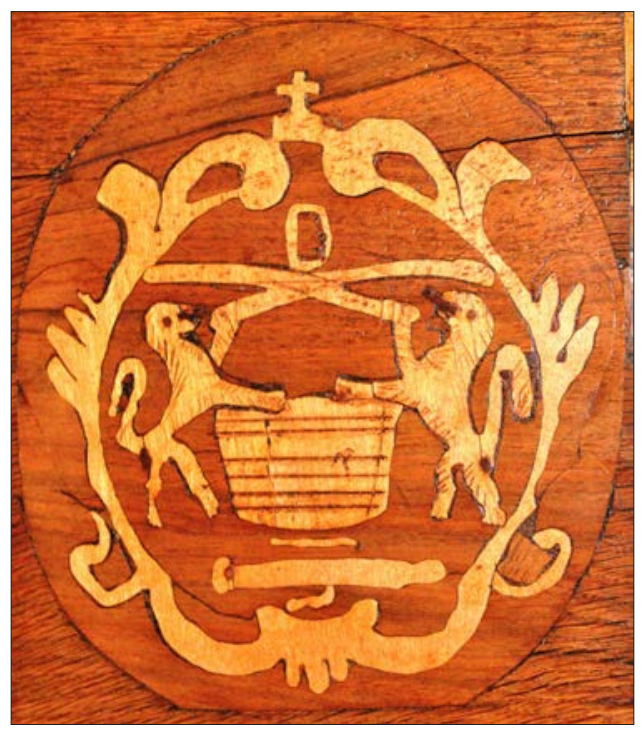

30. kép. Tímárcímer intarziája a céhládán 1863-ból 
1820-ban, a szék 125 falujában 127 lisztelő vízimalom őrölte a helyben aratott és a szék termésének kiegészítésére behozott gabonát. Az összeírásból kimaradt Korond, ahol nagy volt a fazekasok száma. „Korondon minden ember fazakas is; itt készülnek azon mázatlan, és hallatlanul olcsó cserép edények, melyek az egész Székelyföld (kivéve Csíkot) konyhakellékeit fedezik; nyikorgó szekereiken hordják szét a Korondiak ezen gyártmányukat, $s$ azt rendszerént nem pénzért, hanem gabonáért adják el. [...] A falu között lefolyó Korond vizén sok fürész- és lisztelő malom van." A szék malmainak sokkal nagyobb volt a kapacitása, mert voltak két- vagy háromkövűek is.

A bonyolult pénzrendszer változásai nehéz feladat elé állították a piacon eladóként és vevőként is megjelenő kézműveseket. Ráadásul ezekben az években zajlott le az első nagy európai infláció.

Az ország gazdaságára nagy súllyal nehezedett a törököknek fizetett adó, amely évről évre nőtt. Bethlen Gábornak még sikerült a költségvetését egyensúlyban tartani, sőt egyes években a bevétel jelentősen meghaladta a kiadásokat. Pénzügyi politikája sokszor nyomasztóan hatott a céhekre, konkurenciát jelentett a hazai iparnak. Ilyen intézkedése volt az anabaptisták vagy a gdański kézmúvesek betelepítése. Pillanatnyilag ezek az intézkedései nem kedveztek a hazai ipar fejlődésének, de az „ónmázas, ízléses cserépholmik, tálak, bokályok csempék, csészék szinte elöntik a kastélyokat, udvarházakat. Elviszik a színek és formák örömeit a módosabb polgárotthonokba, s olcsóbb kék mázas edényeik mezôvárosok és falvak tehetôsebb házaiban keverednek el a paraszt fazekasok termékeivel" (Makkai - Szász 1986. 933.).

Udvarhelyszéken a sóbányászatnak csak regionális jelentősége volt, de 1670-ben az udvarhelyi református kollégium építésére és fenntartására a sófalvi bánya jövedelméből utalt ki pénzt a fejedelem. A 17. században is nagyobbrészt a céhek látták el a
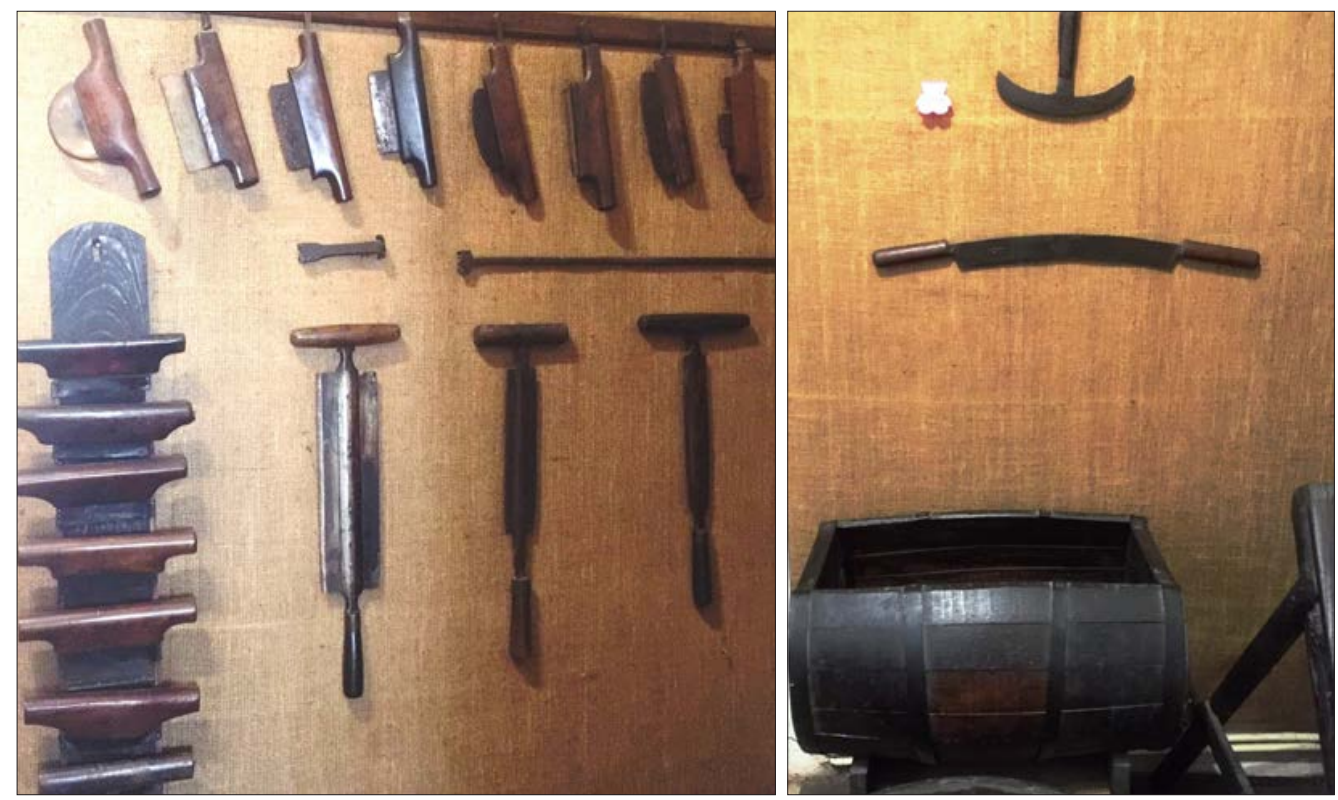

31. kép. Timár mesterek szerszámai a kézdivásárhelyi Incze László Céhtörténeti Múzeumban 


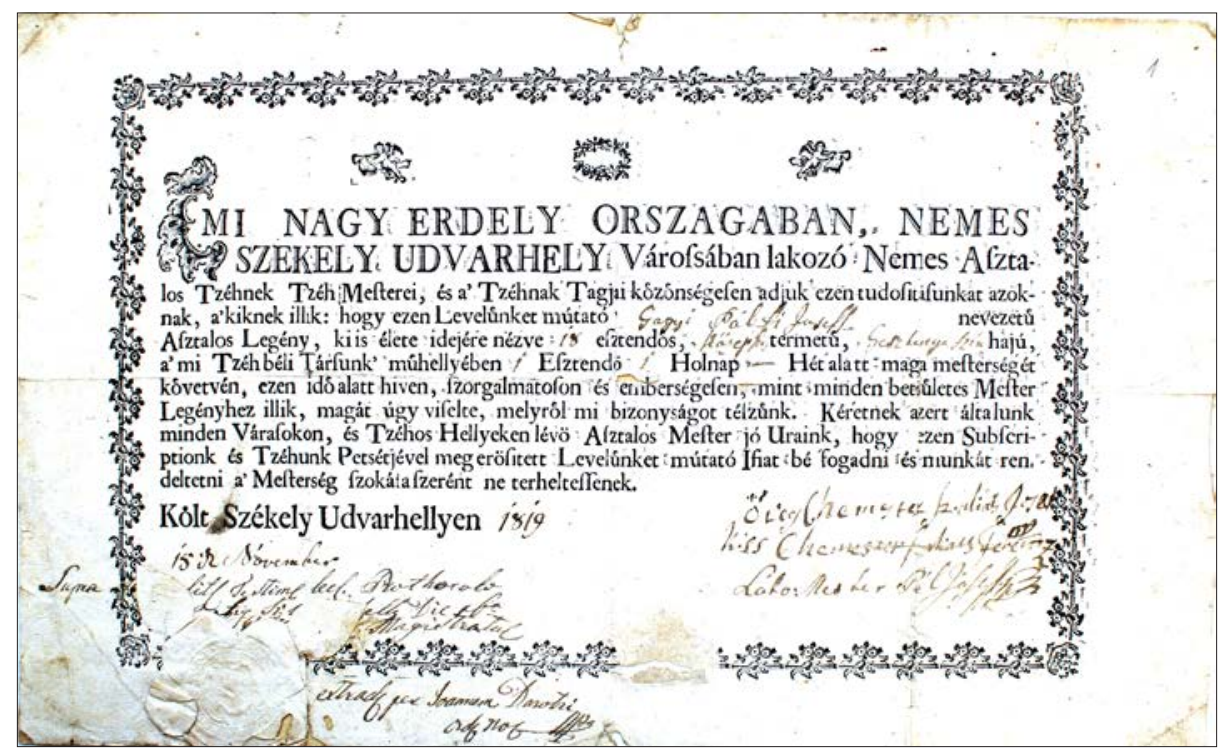

32. kép. Az asztaloscéh munkaigazolása Pálfi József asztaloslegény számára 1819

lakosságot ipari termékekkel. Apafi Mihály ,kéneső üzlet”, amihez vargyasi Daniel István uralkodásának éveiben, 1690 előtt a kincstár (korának talán legbefolyásosabb embere bevételei emelkedtek. Egyik bevételi forrása Udvarhelyszékben) és Macskási Boldizsár, a külföldre irányuló kereskedelem volt. A só- (Belsőszolnok vármegye főispánja) adták val, arannyal, ezüsttel, vassal, higannyal (ké- a szükséges tőkét. 10000 forintot fizettek neső) folytatott kereskedelemből származott be egy közös vállalkozásba, amelynek céla kincstár legnagyobb bevétele. Példa erre a ja az volt, hogy higanyt vigyenek külföldre.

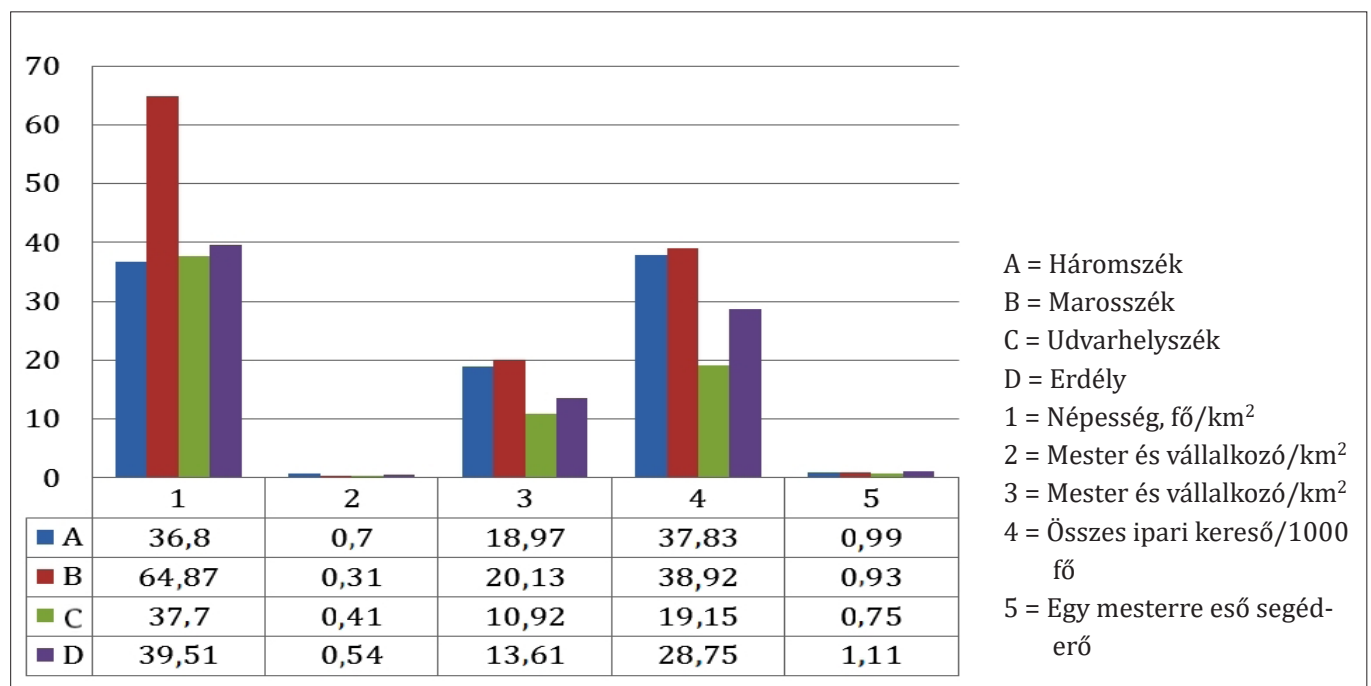

6. ábra. A székely székek összehasonlítása Erdély hasonló adataival 


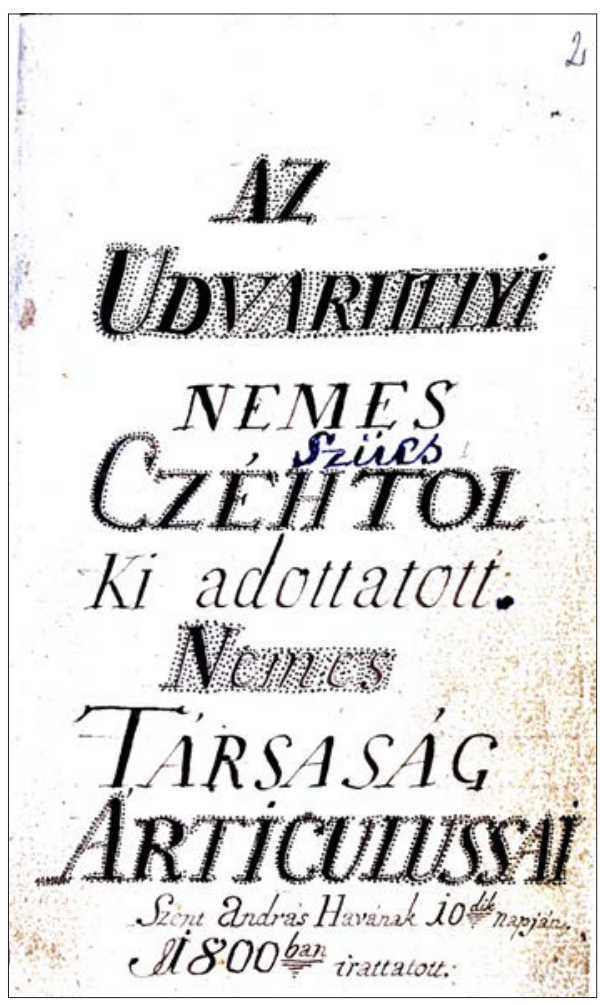

33. kép. A szücs céh artikulusai (1800)

1683-ban Zalatnán 9600 forintra 64 mázsa higanyt vásároltak, és indították el Belgrádba. Eladtak 22 mázsa higanyt 416 Ft 54 krajcárért, a bevételt megbízottaik újra befektették. A bevételt újra áruba fektették, 60 vég „hermelin patyolatot” hoztak haza, és még „két tepsziát” [tepsi] az asszony ő kegyelme számára" és még vásznat és cukrot. Kölcsön is adtak Ábrán zsidónak 245 forintot. 1684. február 9-én az üzletfelek megbízottja, Vízaknai Mihály eladott Bucsi Kozma görög kereskedőnek (Dálnoki 1833) 39 mázsa kénesőt, mázsáját 170 magyar forint értékben, összesen 6630 forint bevétellel. 1683-ban elterjedt a híre, hogy a moldvai vajda 10000 marhát vásárolna, egyenként 1 forint 50 krajcárban darabját. Ez is jó üzletnek ígérkezett, mert a törökök voltak a felvásárlói a hadsereg felszereléséhez szükséges árunak. Később derült ki, hogy a hadsereget Bécs (sikertelen) ostromára készítették fel, és ez volt az oka a szerencsés konjunktúrának (Zepeczaner 2013).

A 18. században az állami beavatkozás egyre nagyobb teherként nehezedett a céhekre, amelyek szívósan védték kiváltságaikat, jogaikat és szokásaikat. Az Erdélyi Fejedelemség csatlakozási alapokmánya a Diploma Leopoldinum volt. Bécsben az erdélyi ügyek vitelére megalakult az Erdélyi Udvari Kancellária. Erdély kormányzását a megalakult Gubernium vagy Főkormányszék végezte (Trócsányi 1988). A tartományt Mária Terézia Nagyfejedelemség rangra emelte.

III. Károly, Mária Terézia és a következő fejedelmek alatt a jobb átláthatóság és kezelhetőség érdekében arra törekedtek, hogy uniformizálják a céheket. Ugyanakkor meg voltak győződve, hogy a céhek a rájuk jellemző, szövevényes privilégiumhálóval akadályozzák a gazdaság fejlődését. Begyűjtötték a privilégiumleveleket tanulmányozás végett, a cél új levelek kiadása és a szabályzatok egész birodalomra kiterjedő egységesítése volt. Elrendelték a katolikus vallási ünnepek megtartását és azt, hogy minden céh vegyen rész a körmeneteken. A céhládákat és a céhvagyonokat ellenőrizték. A Gubernium (1770. október 1. - november 20.) Mária Terézia utasítására, elrendelte, hogy a nőtlen mestereket is felvegyék a céhekbe, betiltotta a mesterasztal és más pazarló lakomák rendezését, csak év végén, a számadás végett összehívott gyűléskor költhettek 12 krajcárt egy-egy résztvevőre. A szabadulólevélbe bekerültek az ifjú mester jogai.

„II. József felismerte, hogy a céhek elavultak és fékei lettek az ipar fejlődésének. A szabad ipar érdekében 1785-ben adta ki azt a gyökeres rendeletét, mely a céhek eltörlésének elvi- 
leg kimondásával, mindenkinek megengedte, hogy bármely ipart szabadon gyakorolhasson." (Szádeczky 1913. 161.) Sajnos II. József, a „kalapos király”, Erdély nagyfejedelmének ez a reformterve sem valósult meg. Halálakor ezt is visszavonta. A rendi társadalom átmeneti győzelmet aratott. ${ }^{19}$

I. Ferenc király uralkodásának éveiben tovább folyt a céhek megreformálása. 1802ben és 1807-ben új, egységesített céhszabályokat adott ki a Főkormányszék. Az 54 pontból álló mintaszabályzat szerint mindenik céh statútumát átfogalmazták. A városokban céhcommissariusokat neveztek ki (akiket a céh fizetett), akik felügyelték a céhgyűlések menetét.

A céhek száma és a művelt szakmák is változtak. Eltűnnek az idejétmúlt mesterségek, mint a pajzsos, a csiszár, a késgyártó. A borbélyokat az orvosi egyetemek végzettjei szorítják ki a gyógyítás területéről. Ugyanakkor újak is megjelennek. Székelyudvarhelyen a kordovánosok és kalaposok alapítottak céhet.

A limitációk és a céhkiváltságok feudális intézmények voltak, amelyek merev rendszert alakítottak ki. A céhek korábbi megtartó bástyái a 18-19. századra már végleg elavultak, az átalakulások, a változások kerékkötőivé váltak. Paradox módon már nemcsak a céhen kívüli ipar fejlődését fékezték, de beszűkítették a céhek mozgásterét is, és a termelés kerékkötőivé váltak. Végső soron, mivel nem fejlődtek a környező világgal, bizonyos mértékben okozói voltak saját maguk pusztulásának.

A 19. században a céhek végleg korszerütlené váltak, privilégiumaikat nem lehetett továbbra is fenntartani. Azt is a számlájukra lehetett írni, hogy akadályozták a társadalmi rendek közötti mozgást.

A kor haladó eszméi elítélték a céhrend- szert (Széchenyi 1828.). „Átka alatt ülnek a szigorú céhrendszernek, amely a legszigorúbb nepotismussal van összekötve, honnan legjobb mester legényeink kénytelenek Oláhországba kiszökni. Minek azon következtetése lett, hogy ott mesteremberekké lévén, a mi gyártmányainkat feleslegessé kezdi tenni Oláhhon piaczain." (Kőváry 1847)

Az ország politikai erői, a császártól a negyvennyolcas forradalmárokig, bármilyen színezetúek voltak is, megegyeztek abban, hogy a céheket fel kell számolni. Ez meg is történt, de már a kiegyezés után, a dualizmus korában, 1872-ben. Pontosan három évszázaddal az első udvarhelyi céh megalakulása után.

Az 1848-as forradalom elötti években Erdélyben tevékenykedő mesteremberek száma Kőváry szerint (Kőváry 1847. 211, 214.):

106 üveges

120 főkötő

123 zsibárus

130 rézműves

141 borbély

141 kéményseprő

172 szappanyos

200 takács

273 pokróc, paplan és matrac

273 posztókészítő és nyíró

299 lakatos

300 fazekas

323 kötélverő

327 kalapos

349 kertész

438 szíjgyártó

712 vendéglős és szakács

716 halász

756 kőműves

799 bérkocsis és fuvaros

858 kádár

903 kenyérsütő

952 asztalos 
1353 mészáros és hentes

1354 muzsikás

1618 szabó

1810 szűcs

1810 tímár és kordovános

2614 pálinkafóző

3124 molnár

3592 fogadós

\section{5 csizmadia}

A történelmi (vagy Belső-) Erdély lakossága 2010517 volt. A különböző mesterséget „űzők” száma, akik meghaladták a 100-at egy-egy mesterségen belül, összesen 42663 volt, ami azt jelentette, hogy a Nagyfejedelemség 4,71\%-a dolgozott az iparban és szolgáltatásokban. Ezeken kívül még ide kell számoljuk a falusi, az őstermelésben dolgozó különböző mesterségeket kiegészítő foglalkozásként űző kézműveseket, mint az ács-, faragó-, esztergályos- stb. mestereket. Az erdélyi bányák 10410 bányászt foglalkoztattak. Kézművesmesterséget is folytatott a cigányok egy része, de a muzsikusokat 1345 számmal beszámították a mesterséget folytatók közé, akik szintén nem jelentek meg ebben a statisztikában. Jellemző, hogy a legtöbb mestert foglalkoztató ágazatokban benne vannak a fogadósok, pálinkafőzők és a zenészek, összesen 7560 mester, vagyis a dolgozók 18\%-a.

A 19. században a céhek egyre inkább teret veszítettek a szabad iparral és kereskedelemmel szemben. Az 1852-ben Kolozsváron kiadott Ideiglenes utasítás a kereskedés- és Iparviszonyok Szabályozására Erdély Koronaországban 2. paragrafusa a kereskedést négy ágazatra osztotta:
A. Szabad kereskedés,
B. Kalmári kereskedés,
C. Szatócsság,
D. Házaló kereskedés.

A „gyárügyekkel” a II. fejezet foglalkozik.
61.§. „Gyároknak neveztetnek azon iparüzleti vállalkozások, melyek, minthogy üzleteiket nagyobb mértékben folytatják, tehát sok embert foglalatoskodtatnak, tetemes beköltött pénzösszeget kívánnak, terjedelmes forgalmat tartanak fen, a saját engedményeik alapján terjedelmesebb üzleti jogot (országos gyárnok szabadalmat) nyertek." A céhügyeket a 110-222. paragrafusok rendezik. A 111. paragrafus szerint: „Elvül tartandó, hogy a céhek csupán szabad, iparüzleti, jótékony és vallásos célok elérésére és iparrendôri felvigyázat végett tartatnak ott fen, ahol léteznek..." A céhektől megvonták korábbi legfontosabb jogaikat. Nem követelhettek meg olyan kizárólagos jogokat, melyeket korábban privilégiumaik alapján birtokoltak, csak azokat gyakorolhatták, amelyek azok nem ellenkeztek az iparrendszabályokkal és a céhszabályokkal.

A céhek megszűnésének következő állomása az 1859. december 20-án kiadott császári nyílt parancs volt, amely életbe léptette $A z$ új Iparrendet. Az iparűzés általában engedélyezetté vált. Végül az 1872. VIII. és az 1884. XVII. tc., a két Ipartörvény leszögezi, hogy „ $A$ magyar korona országai területén minden nagykorúnak nyílvánitott egyén, nemre való tekintet nélkül, ezen törvény bármely iparágat, ideértve a kereskedést is, bárhol, önállóan és szabadon gyakorolhat."

\section{Jegyzetek}

1.Az „ipar” szó „mesterség” értelemben csak 1847-ben jelent meg. Lásd Erdélyi magyar szótörténeti tár. V. Anyagát gyűjtötte és szerkesztette Szabó T. Attila. BudapestBukarest, 1993. 748. Azonban használata a korábbi időszakokra is szokásos.

2.Sópiac = itt vásárolhatták meg a parajdi sót a sókereskedelemmel foglalkozó szekeresektől. 
3.1670. évi országgyűlés „XXII. art. Levén székely atyánkfiai közt lakó szegénységnek, kik az sóval való kereskedéssel kényszeríttetnek életeket táplálni, ilyen megbántódások, hogy sokan közűlök megkárosíttatnak városokon sokadalmokon, nem producáltatván minden a kamaraispán, vagy számtartó testimonialisát; mivel sokak közülök Udvarhely városában veszik a sót olyanoktúl, a kiknél feles savakrúl vagyon ugyan közönséges cédulájok, de az cédulát nem adhatja mindenik vivőnek, a kik kevés számú sót vesznek tőlök; azonba az arra való inspektor városokon sokadalmakban megkárosítja őket. Kegyelmes urunk, hogy Nagyságod arra igéri magát, parancsol felőle, hogy az ilyen szegény embereket meg ne károsítsák, Nagyságodnak alázatosan megszolgáljuk." Erdélyi Országgyűlési Emlékek (a továbbiakban EOE) XVI. Budapest, 1893. 176.

4.Udvarhelyszékben az emberi táplálkozás és az állatok takarmányozása számára soha nem volt elég a határain belül megtermelt gabona.

5.Daniel Gábor, 1861-1891 között Udvarhely vármegye fóispánja emlékirataiban megjegyezte: „A zetelaki vagy oroszhegyi erdőből lopott fából ezerekkel hordják a zsindelyt az udvarhelyi piacra." 1893. évi bejegyzés. (Kézirat a HRM tulajdonában.)

6. Hivatalosan csak akkortól tekinthetjük megalakultnak egy céhet, ha privilégiumlevelet, statútumot, szabályzatot kapott a várostól vagy a fejedelemtől.

7.A székelyudvarhelyi céhek irományait 1952-ben a Városi Múzeumba (ma Haáz Rezső Múzeum) adták be megőrzésre a céhek jogutódai, a megszüntetett ipartársulatok. Később a Román Nemzeti Levéltár Hargita megyei Igazgatóságának kezelésébe kerültek. A gyüitemény neve Colecția Muzeului din Odorheiu Secuiesc, a Székelyudvarhelyi Múzeum Gyűjte- ménye. Fond 249. A Székelyföldön az udvarhelyi céheké a legnagyobb fennmaradt céhiratgyüjtemény.

8.„Nem kicsiny panaszolkodásunk vagyon, kegyelmes urunk, az míves emberek felöl is, holott noha arról egész országul közönségesen limitációjuk vagyon, mint és hogy kellessék marhájokat [itt piacra vitt, eladásra szánt termékeik] adni, az bor is mostanában főképpen olcsó, [...] illetlen és felettébb való árat szabták marhájoknak. [...] az limitáció igen observáltassék, különben marháját senki ne adja, ha különben cselekednek és a várasbeli magisztrátus nem exequáltatja külső ember instantiájára, az nemes ember certifificálván az vármegye ispánjit, az város jószágán mox et defacto kétszáz forintot exequálhasson, melyre ezen constitutiónak vigorával authoritás adatik az ispánoknak." (EOE. VIII. 1882. 98.)

9.Ez óriási összeg volt. Egy zsoldos lovas katona havi járandósága öt, egy gyalogos zsoldja három forint volt.

10.„Az várasbeli uraink, kegyelmes urunk, nemességünk szabadsága ellen olly privilegiumot, szabadságot találtanak, és oly szokást követnek, hogy vagy maguk majorságából, vagy szegény községeink marhájából valami marhát bevisznek várasokba eladni, prohibeálják az várasbeliek, hogy idegen embernek szabad ne legyen megvenni, se el adni, mindaddék valamég ő magok az város népe nem vásárolnak, magok rendelik penig el, mint és hogy adják nekünk nagy fogyatkozásunkra. [...] Könyörgünk Felségednek efféle abususok poenius Tolláltassanak."

11.„Az mely új keresztyének, kegyelmes urunk felséged jó akaratjábul ez országban bejöttenek és immár ugyan meg is telepedtenek, Felséged kegyelmes parancsolatja szerint azoknak állapotjokról országúl így végeztünk, hogy azoknak az új 
keresztyéneknek és az kiket magok mellé azután behozhatnának is ez országban, minden névvel nevezendő mesterségek szerint való munkájok szabadosan exerceálhassák. Az melyet penig tudniillik Alvincet, Felséged nekik rendelt, abban a helyben religiójukkal is az ő szokások szerint szabadon exerceállhassák és senki őket abba meg ne háborítsa."

12.1623. június 23. (EOE. VIII. 1882. 143145.)

13.1828. áprilisi országgyűlés.

14. A források a földmérés eszközéül láncot is említenek, Udvarhelyen ezt „kötéllel” végezték. (A szöveget átírva idéztem). (Székely Oklevéltár. 1983. 41.)

15. Magyarország mértékeit Bogdán István egy 760 oldalas könyvben mutatta be: Magyarországi ür-, térfogat-, súly-, és darabmértékek 1874-ig. Bp., 1991.

16. Arasz $=23,7 \mathrm{~cm}$, hüvelykes tenyér $=11$ $\mathrm{cm}$, így a zsindelymérték $=11,0 \times 71,10$ cm. Lásd Bogdán István: Magyarországi ür-, térfogat-, súly- és darabmértékek 1874-ig. Budapest, 1991.

17. Tabella de numero et statu Zingarorum in inclito sede Siculorum Bardósz. (1781. 1 Martii). (Jakab-Szádeczky 1901. 530.)

18. magyar mérföld = 8353,5 m; osztrák mérföld $=7585,94 \mathrm{~m}$.

19. Ahogyan később a haladáspártiak emlegették: „A fürdővízzel kidobták a gyermeket is."

\section{Felhasznált irodalom}

Approbata Constitutiok. Approbatae Constitutiones Regni Transylvaniae et Partium Hungariae Eidem Annexarum. Ex Articulis ab Anno Millesimo Quingentesimo Quadragesimo (etc.). Kolozsvár, 1815.

Bónis Johanna: A marosvásárhelyi céhekről. A Maros megyei magyarság történetéből. Mv., 1997.
Csetri Elek: Az erdélyi gazdasági gondolkodás 1800-ig. Kv., 1999.

Dálnoki Incze József: A görög kereskedőkről. Lásd Értekezés A' N. Szebeni és Brassói Görög Compániákról. Nemzeti Társalkodó, 1833. 5. sz. 65-71; 6. sz. 86-73; 7. sz. 97-99.

Erdélyi magyar szótörténeti tár. VII. Anyagát gyűjtötte és szerkesztette Szabó T. Attila. Budapest-Bukarest, 1995.

Erdélyi Országgyúlési Emlékek III. 1576-1596. (EOE. III.) Budapest, 1877.

Erdélyi Országgyúlési Emlékek VI. 1608-1614. (EOE. VI.) Budapest, 1880.

Erdélyi Országgyúlési Emlékek VIII. 16211629. (EOE. VIII.) Budapest, 1882.

Erdélyi Országgyúlési Emlékek XVII. 16791682. (EOE. XVII.) Budapest, 1894.

Finály Henrik: A régi magyar súlymérték. Adalék a hazai pénzverés történetéhez. In: Az Erdélyi Múzeum-Egylet Évkönyve. 4. kötet, 1. füzet (1866-1867).

Gazda Klára: A székely népviselet. Budapest, 1998.

Honvári János (szerk.): Magyarország gazdaságtörténete a honfoglalástól a 20. század közepéig. VII. kiadás. Budapest, 2002.

Huszár Lajos: Az erdélyi fejedelemség pénzverése. Budapest,1995.

Imreh István: Céhbeli kézművesek, népi mesterek és vásárlókörük (1750-1830). In: Erdélyi hétköznapok. Társadalom- és gazdaságtörténeti írások a bomló feudalizmus időszakáról. Bukarest, 1979.

Imreh István: A fejedelmi gazdálkodás Bethlen Gábor idejében. Erdélyi eleink emlékezete (1550-1850). Társadalom és gazdaságtörténeti tanulmányok. Kv., 1999. Lásd még Hagyomány és korszerüség az állattartásban. Korunk. 1966. 3. 356-361; Adatok Udvarhelyszék mezógazdaságához. (1570-1610). Aluta. 1969. 131-141. Társszerző Pataki József; Adatok Udvarhelyszék állattartásához. Aluta. 1970. 169-184. Társszerző Pataki 
József; Kelet-európai és hazai agrárpolitika a feudalizmus alkonyán. Korunk. 1972. 9. 1359-1364; A székely falu társadalmi szerkezete a XVII. század elején. Korunk. 1976. 5. 374-378.

Imreh István: Erdélyi hétköznapok. Társadalom és gazdaságtörténeti írások a bomló feudalizmus időszakában. Bukarest, 1979. 169-198.

István Lajos: Visszaemlékezés a korondi sokadalmakra. Kézirat. 1977.

Jakab Elek - Szádeczky Lajos: Udvarhely vármegye története a legrégibb időtől 1849ig. Budapest, 1901.

Jakó Zsigmond: Az erdélyi mértéktörténet kérdéséhez. Írás, levéltár, társadalom. Budapest, 2016. 471.

Kardalus János: A négynapos sokadalom Bögözben a századforduló után. Művelődés, 1985. 10. 28

Kovách Géza - Binder Pál: A céhes élet Erdélyben. Bukarest, 1981. 57-65.

Kőváry László: Erdélyország statistikája. I. Kolozsvárt, 1847.

Kozma Ferenc: A Székelyföld közgazdasági és közmívelődési állapota. Kiadja a Székely Mívelődési és Közgazdasági Egylet, Budapest, 1879. (Reprint, Székely Nemzeti Múzeum, 2008)

Lakatos István: Székelyudvarhely legrégibb leírása. Fordította Jaklovszky Dénes. Kolozsvár, 1942.

Laukó Albert: Udvarhely város leírása. 1888 395. 46

Makkai László - Szász Zoltán (szerk.): Erdély története. II. 1606-tól 1830-ig. Budapest, 1986.

Molnár István: Keresztúri sokadalmak. Hargita Kalendárium 1974.

Nagy Ferenc: Vásárlaistrom - a vásáros helyeket jellemző áruczikkek' szempontjából. In: Nagy Ferenc (szerk.)> Mentor. Erdélyi népkönyv 1. Közhasznu ismeretek tára a' honi szorgalom, 's értelmesedés előmozdítasára. Kolozsvár, 1842.
Orbán Balázs: A Székelyföld leírása történelmi, régészeti, természetrajzi $s$ népismei szempontból. I. Pest, 1868.

Paál-Antal Sándor: Marosvásárhely története. I. A kezdetektől 1848-ig. 2009; Uő: Történeti szimbólumaink. Székelyföldi pecsétek. Marosvásárhely, 2014.

A Román Nemzeti Levéltár (RNL) Hargita megyei Igazgatósága. A székelyudvarhelyi Múzeum Gyűjteménye. Fond 249. 36, 38 sz. [A továbbiakban CL.]

Szádeczky Lajos: Iparfejlődés és a czéhek története Magyarországon. I. Bp., 1913.

Szakály Ferenc: Virágkor és hanyatlás 14401711. Bp. 1990.

Széchenyi István: Hitel. 1828-1829.

Székely Oklevéltár. (SzO.) Új sorozat. Közzéteszi Demény Lajos és Pataki József. I. Bukarest, 1983.

Székely-Udvarhely rendezett tanácsú város piacrendezési terve országos és hetivásárok alkalmával. In: Udvarhely-vármegye szabályrendeletei. Székely-Udvarhelyt, 1898 és Székely-Udvarhely rendezett tanácsú város piaci helypénz szabályzata. Székely-Udvarhelyt, 1897. Újrakiadva: Zepeczaner Jenő: Itten esztendőnként négy sokadalmak és heti vásárok szoktak esni. Örökségünk 2. 24-25; Uő: Székelyudvarhely piacrendtartása 1893-ban. Örökségünk 2010. 3. 15-17.

Szeles János - Szájdler János: Székely-Udvarhely története. Erdélyi Múzeum 15/10. (1898).

Szigethy Gyula Mihály: Nemes Udvarhely-Szék statisztikai leírása. Nemzeti Társalkodó, 1831.

Szigethy Gyula Mihály: Nem csupán az elme élesítésére, hanem a' közhaszonra készíttetett Méréstudománya. Felső Magyarországi Minerva. Nemzeti folyó-írás. (Kassa). 3/1834.

Sonkoly Gábor: Vásárok, vásárkörzetek és városok Erdélyben 1820-ban. Korall 1112./2003. 168. 
Takács Péter (sajtó alá rendezte): Udvarhelyszék parasztvallomásai 1820-ból. In: Források Erdély Történetéhez 1. Erdély-történeti Alapítvány, Debrecen, 2001.

Téglás György 1910. 3. 54.

Trócsányi Zsolt: Erdély központi kormányzata 1540-1690. Budapest, 1980.

Trócsányi Zsolt: Habsburg-politika és Habsburg-kormányzat Erdélyben 1690-1740.
Budapest, 1988.

Vámbéri Gusztáv: A font súly. Budapest, 1975.

Werbőczi István: Nemes Magyarország szokásjogának Hármaskönyve. Az ország jogainak és szokásainak harmadik részéről általában 7. §. 1514.

Zepeczaner Jenő: A kéneső üzlet. Örökségünk, 2013.1.13. 


\section{MELLÉKLET}

\section{SZÉKELY-UDVARHELY RENDEZETT TANÁCSÚ VÁROS PIACRENDEZÉSI TERVE ORSZÁGOS ÉS HETIVÁSÁROK ALKALMÁVAL}

\section{1. §. Általános elvek}

Általános elvül kimondatik az, hogy Sz.-Udvarhely város piacterén tilos a fát behozó és lerakó egyéneknek üres szekereit bárhol is megtelepíteni. Tilos a deszkás szekereknek benn a városban bármelyik utcában vagy piactéren megtelepedni. Tilos az úgynevezett molnár szekereknek vagy malomba járóknak az utcákon és tereken megtelepedni. Tilos a cserfás szekereknek benn a városban megtelepedni hétköznap úgy, mint vasárnap alkalmával, csakis a külső fapiacra utaltatnak. Az üzlethelyiségek előtti járdának úgy országos, mint heti vásárokon, valamint hétköznapokon is egyes árucikkekkel elfoglalása tilos. A közlekedési utak fel nem használhatók vásárterekül s az egyes terek is csak úgy használhatók fel, hogy a szabad közlekedés sehol fenn ne akadjon, s véletlen tűz vagy más szerencsétlenség alkalmával a szabad közlekedés fennmaradjon s ezen kívül a rendőrségnek a felügyelet gyakorolhatása végett mindenütt nyílt járhatása legyen. Kimondatik az is, hogy a mely helyekre gyümölccsel vagy cserépedényekkel, zöldséggel terhelt szekerek engedtetnek megtelepedni, ott lovakat, szarvasmarhákat s más igavonó állatokat az áruhelyen tartani tilos. A gabonával és egyéb rakománnyal terhelt szekerekre nézve ezen kedvezmény nem adatik, hanem az illető árusok kötelesek gabonájukat vagy egyéb árucikkeiket a kijelölt helyen lerakni és igavonó állataikat szekereikkel magán udvarokban, vendéglőkbe vagy a város által e célra kijelölt helyre eltávolítani.

\section{2. §. Elhelyezések}

A mérnöki felmérés szerint a felső-, piac-, templom-, városház-, és alsópiacterek a közlekedési utak leszámításával 9389 négyzetméter területet foglalnak magukban, melyek hasonfele a felsőpiactérre esik, ezért és azért is, mert minőségénél fogva legalkalmasabb tér legcélszerúbben hasznosítható. Ezután következik a Kossuth-utca szabad tere 5449 négyzetméter területtel, melybe szintén nincs beleértve a közlekedési útvonal. Azután jön a Szombatfalvi-utca külön tere 800 négyszögöl területtel és a kőkereszt körüli tér 500 négyzetméter területtel. Ezeket szem előtt tartva és szemelőtt tartva az egyöntetüséget is, legcélszerübbnek mutatkozik a következő elhelyezés.

\section{A) Felső́piac-tér}

Az összes nagysátrak, melyekben készruhák, singes árucikkek árultatnak, ide értve a galantéria és tótok sátrait is, a felsőpiacon déltől északi irányban helyezendők el mind, a következő sorrenddel: A ruhasátrak a kúttól kezdve a tér közepén helyeztetnek el egymással szemben két sorban; ezek mellé a déli oldalon a takácsok, flanel árusok, falusi szőttes árusok sátrai, északi oldalon a tótok, ezek végébe és velük szembe a singes kereskedők sátrai. Az összes sátraknak a nyugati végeknél, a közlekedési útig helyezendők el a galantéria sátrak, keleti végénél az északi oldalra jönnek a szíjgyártók, nyugati oldalon a szitások, a cserge és pokróc árulók. Az ev. ref. kollégium bejárójától felfelé az épület közelében a szalmakalaposok. Az ev. ref. templom 
oldala mellett hosszában elkezdve a kollegiummal szemben lévő bolthelyiség szögletétől a templomnak másik szögletén lévő bolthelyiségig a lakatosok és pléhesek. Az ev. ref. templom északi végén lévő bolt szögletétől a szíjgyártók boltja szögletéig, továbbá jobbra a Kassay Ignác házától a megyeházának bejárójáig azon pityóka, hagyma, káposzta és egyéb vetemény árusok, a kik szekér nélkül árulnak.

\section{B) Templom-tér}

A szőcsök két sorba a szíjgyártó bolt elejébe helyezendők, velök egy vonalba, háttal vagy szemben, a mint a helyzet megengedi, az összes pogácsások sátrai, kik között az úgynevezett mandulás pogácsások elsőséggel bírnak, ugyanide helyezendők a nyigocások és a durva kalapot árulók sátrai, úgy hogy a fazakasok és mészárosok boltjai előtt egészen keresztül legalább 2 méter szélességű hely, [hogy] a közlekedés fennmaradjon.

$\mathrm{Az}$ ev. ref. templom szögletétől kezdve a fazekasbolt szögletéig elhelyezendők az órások és ékszerészek sátrai olyformán, hogy az órások sátrai felfelé essenek és a fazakasok boltja szögleténél két méter széles szabad átjáró maradjon fen, a sátrak homlokkal az ev. ref. papilakkal szemben legyenek. A fazekasbolt déli oldalához a fésűsök és más apró sátrak vagy padon árulók helyezendők.

\section{Kossuth-utca}

A Flórián Bogdán háza felső szögletétôl a boltokba bejárást és a szabad közlekedést nem akadályozólag a járda előtt helyeztetnek el a kés, kefe, kötél, finom kalap, kis gyermekruha árusok és cukrászok sátrai, a baloldalon a rövidárusok sátrai mellé, a városháza felé irányozva a kesztyúsök, condra árulók sátrai és azok végéhez az iparosok által kiállított szekerek. A cukrász és rövidárusok sátrai után lefelé, azaz délre irányozva, egymással szemben két sorban a cipészek, utánuk a csizmadiák sátrai, ezen sátrak hátánál a járdán a közlekedést nem akadályozólag helyeztetnek el a gabona árusok. Ezek után, jobbra és balra egymással szemben a gyümölcsárusok szekerei és a Maros-Torda megyei zöldségárusok szekerei, a mennyiben az alsó piacról ide utaltatnak, ezek után, szintén egymással szemben az asztalosok és az összes faedény árusok, ide értve a kártya, cseber, kád, tekenyő, lapát, seprű, fakanál, stb. cikkek, továbbá a gyékényesek.

\section{Alsópiac-tér}

Balra a házak mellett egymással szemben két sorban a tímárok és kordoványosok. A vidéki rom. kath. papság háza előtt helyezendők, midőn panorámás és körhintajátékos nincsen, a Maros-Torda megyei zöldségárusok szekerei, ezek előtt maradnak a pecsenyesütők és kenyérárusok. Ezek elébe helyezendők a szappanosok és tejárusok s apró kosarakban és padatlan helyi és idegen gyümölcsárusok. A városház alsó szögletétől kezdve egymással szemben két sorban helyezendők a finomabb edényeket áruló kászoni, parajdi, makfalvi és más községi fazekasok sátrai, üvegesek és porcelánosok sátrai elsőbbséggel bírván, a városház szögleténél egymással szemben két sorban, a közlekedést meg nem akadályozva helyezendők el a helybeli fazekasok. A mely tér a pecsenye- és kenyérsütők előtt a közlekedési úttól balra fennmarad, továbbá a barátok kertje melletti tér a szabad közlekedést nem akadályozólag és az idegen fazekasok és a falusi hentesek sátrai között a városház háta megett fennmaradott tér fordítandó a korondi fazekasok elhelyezésére.

\section{E) Városház-tér}

A városháznak felső szögletétől lefelé, a Szombatfalva felé vezető közlekedési út széléig egymással szemben két sorban helyezendők el a falusi hentesek sátrai és padjai és 
a hagyma árulók, szekerek azonban itt sem engedtetnek meg. A városházatéren ugyanezen megszorítások mellett helyezendők el a mészáros ipartársulat tagjainak és egyes helybeli mészáros iparosoknak kitehető sátraik és padjaik. Ugyan e téren a szőcs és mészáros bolttal szemben helyezendők el a szalonnát és mézet árulók sátraik és padjaik. A Szenkovics János boltja elejébe a sóshal árusok, azon felül a kása és lisztnemü árusok, azon felül a fejtősök sátrai, a füszeres boltok előtt azon finomabb kosár- és szotyorárusok, kik pad nélkül árulnak. A sóshal- és lisztárusok előtt közvetlenül a közlekedést meg nem akadályozólag a szekérnélküli sajtárusok.

\section{F) Kereszt-tér}

A falusi posztó árusok, rongyászok vagy ószeresek.

\section{G) Szombatfalvi-utca}

A gyapjú és nyersbőr árusok.

3. §. Heti vásárok alkalmával az országos vásári elhelyezésektől következő eltérések irányoztatnak elő:

\section{A) Felsőpiac-tér}

A felsőpiac-tér a gabona árulás piaca; a gabona, pityóka, efféle árucikkek a kúttól keleti irányban a tér közepén két, esetleg több sorban úgy helyezendők el, hogy két oldalt, az épületek mellett, a kocsi közlekedésre szabadon elég tér maradjon. A gabona árusok az áruló helyről szekereiket és igavonó állataikat eltávolítani kötelesek.

\section{B) Templom-tér}

A szőcsők és szíjgyártók a boltokban árulnak. Ide helyeztetnek a tótok sátrai, a többiek, a kik az országos vásárra ide utaltatnak, a mennyiben kirakódnak, maradnak helyeiken.

\section{C) Városháza-tér}

A fazekasbolt és a városház közt a Kos- suth-utcával szemben helyeztetnek a mézespogácsások és kifliárusok sátrai; különben marad az országos vásári elhelyezés.

\section{D) Kereszt-tér}

Marad az országos vásári elhelyezés.

\section{E) Alsópiac-tér}

A tímárok a boltokban árulnak. A gyümölcsárusok szekerei utaltatnak a megyei róm. kath. papság bérháza elébe, a vetemény árusok pedig a városháza szögletétől a barátok felé egy vonalba. A város szögletháza felső szegétől egymással szemben két sorban a kézzel hozott vetemények számára, a helybeli kufárok és kofák a pecsenyesütők elejébe külön helyezendők el és pedig azért, hogy a vásárló felismerhesse őket, a kik a lakosok terhére nyerészkednek és az idegen árusoktól már akkor reggel mindent összevásárolnak, ugyanezen térre helyezendők el, a mennyiben jönnek az idegen fazekasok és kosarakbani gyümölcsárusok. A korondi fazekasok maradnak a maguk helyén, hasonlólag a falusi hentesek, gyapjúárulok és mások, a kik az országos vásárnál megemlítettek.

\section{F) Kossuth-utca}

Ide utaltatnak a káposzta árusok szekerei, condra árulók, cukrászok, kasza, köszörúkő árulók és efféle apróbb sátrak helyeztetnek a Flórián Bogdán háza alsó szögletétől felfelé s azzal szemben a míg elférnek, úgy, hogy a közlekedés megakadályozva ne legyen. A mennyiben a gyümölcsárusok szekerei az alsópiac-téren el nem helyezhetők, a Kossuth-utcában az országos vásári helyökre utaltatnak. Minden más rendezés marad, mint az országos vásár alkalmával.

4. §.Hétköznapokon, a mennyiben vásári elhelyezésre szükség lesz, a heti vásári elhelyezés irányadó.

5. §. Az országos- vagy hetivásárokon, a 
mennyiben apróbb árusok olyanok jelentkeznek, a kik árucikkeikkel kevés helyet foglalnak el, az ilyeneket, hogy a közlekedés meg ne legyen akadályozva, alkalmas helyre beosztani és a mennyiben kijelölt helyeiken az egyes árusok el nem férnek, vagy kiknek tér kijelölve nincsen, azokat belátása szerint elhelyezni a rendőrfőkapitány feljogosíttatik.
6. §. Ezen tervezet keresztülvitele és felügyeletével a városi rendőrkapitányság bizatik meg.

Sz.-Udvarhely város képviselőtestületének 1893. évi június hó 24-én tartott üléséből.

Gálffy Endre, föjegyző.

Kassay F. Ignác, elnök, polgármester. 